Situk River Hydrology Following Closure of Russell Fiord by Hubbard Glacier

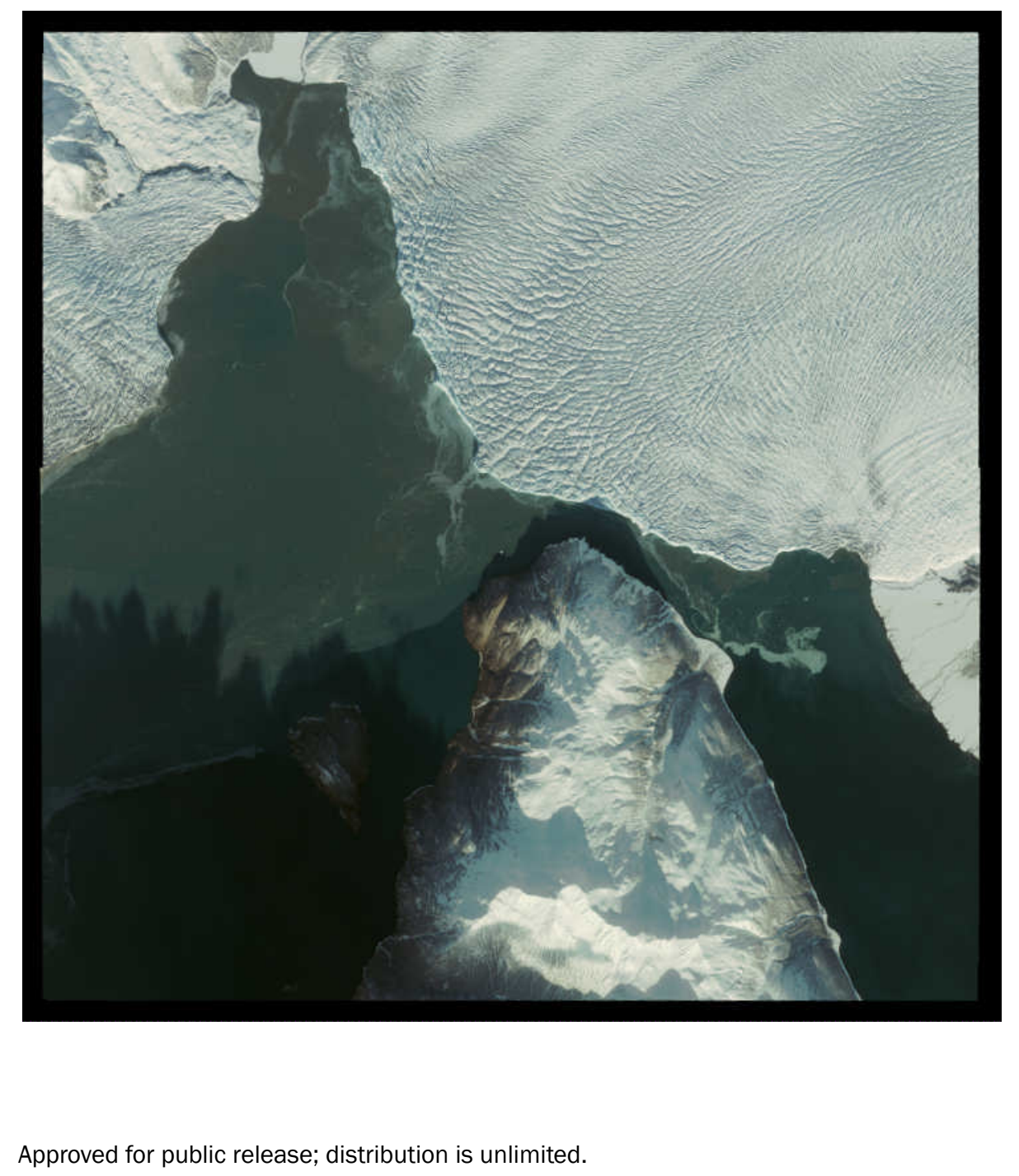




\section{Situk River Hydrology Following Closure of Russell Fiord by Hubbard Glacier}

Steven F. Daly, Carrie Vuyovich, and David Finnegan

Cold Regions Research and Engineering Laboratory

U.S. Army Engineer Research and Development Center

72 Lyme Road

Hanover, NH 03755-1290

Approved for public release; distribution is unlimited.

Prepared for U.S. Army Corps of Engineers

Washington, DC 20314 


\begin{abstract}
The impact on the hydrology of the Situk River of a sustained closure of Alaska's Russell Fiord by Hubbard Glacier is described. A hydrological model was developed and used to estimate the daily inflows into Russell Lake (created by the closure of Russell Fiord). These daily inflows, when routed through Russell Lake, determine the flow into the Old Situk River after the Russell Lake level has risen approximately $137.2 \mathrm{ft}$. A HECRAS one-dimensional flow model estimated the levels and flows of the Situk River system, including the Old Situk, Upper Situk, and Lower Situk rivers. The channel geometry was based on an extensive LiDAR survey conducted in 2005. The levels and flows in the Situk River system were simulated over 15 years using the estimated daily outflows from Russell Lake to determine the hydrology of the Situk River system. The flow percentiles, annual exceedance probabilities, and average daily flows were estimated. The flow profiles were used to develop inundation maps and investigate potential channel erosion, the impacts on the Old Situk River crossing and Situk Lake, and the potential influence of logjams and channel migration.
\end{abstract}

DISCLAIMER: The contents of this report are not to be used for advertising, publication, or promotional purposes. Citation of trade names does not constitute an official endorsement or approval of the use of such commercial products. All product names and trademarks cited are the property of their respective owners. The findings of this report are not to be construed as an official Department of the Army position unless so designated by other authorized documents. 


\section{Contents}

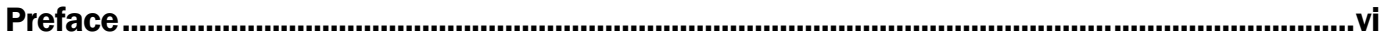

Unit Conversion Factors............................................................................................................vii

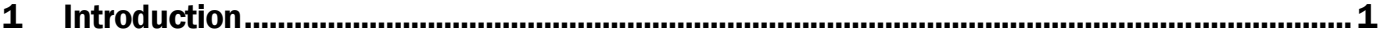

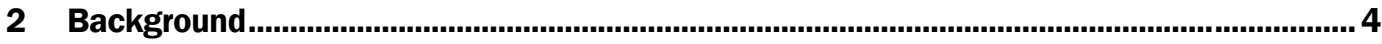

Hubbard Glacier Closure .......................................................................................... 4

Situk River Watershed........................................................................................ 5

3 Russell Lake Hydrology Following Closure of Russell Fiord.................................................. 9

4 Situk River System Flow Simulation ......................................................................................19

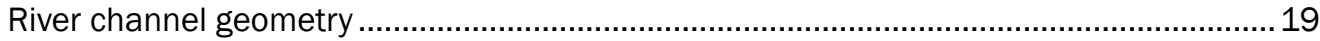

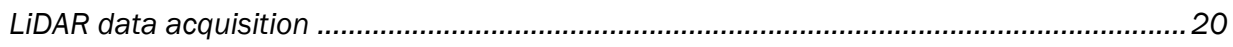

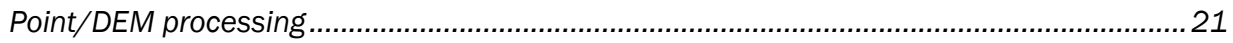

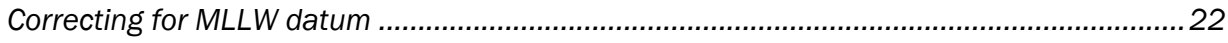

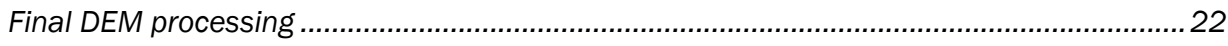

Estimating the channel flow resistance ............................................................................. 23

Development of HEC-RAS geometry for Situk River ......................................................... 26

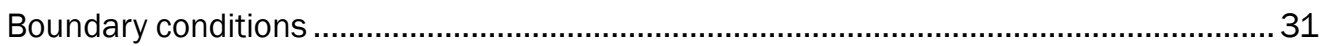

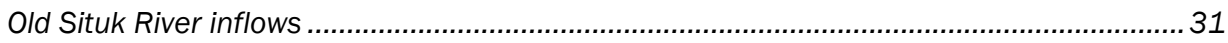

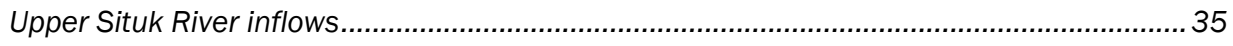

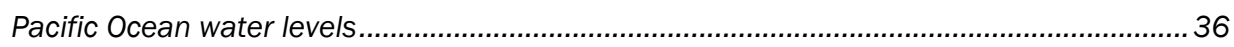

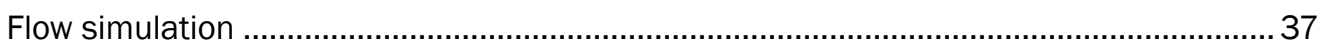

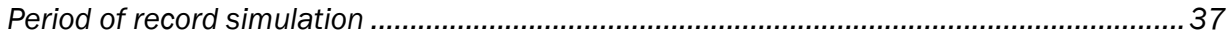

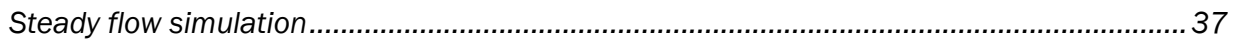

5 Hydrology of the Situk River System Following Closure of Russell Fiord ..............................39

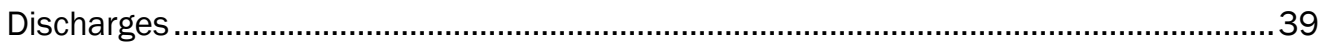

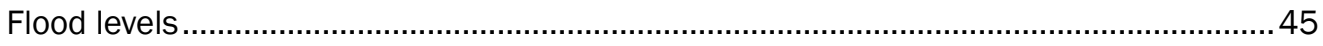

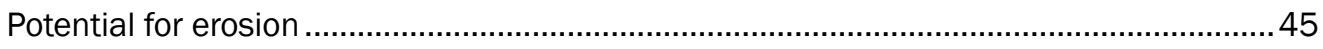

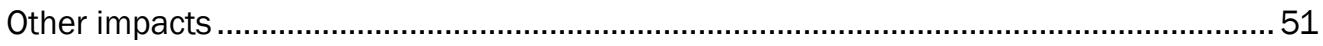

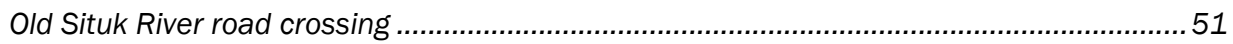

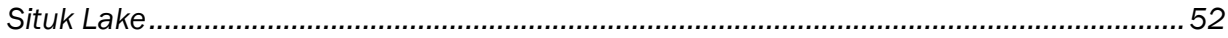

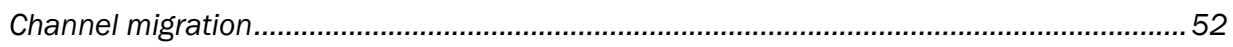

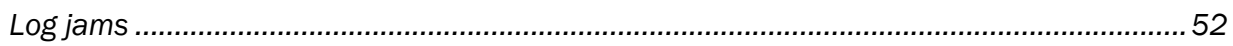

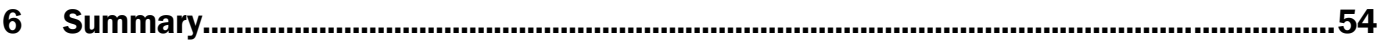

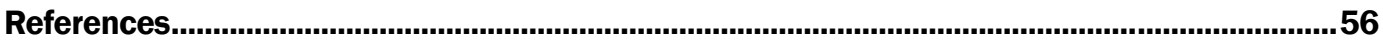

Appendix A: Cross Section Information.............................................................................

Report Documentation Page 


\section{Figures and Tables}

\section{Figures}

Figure 1. Location map showing the town of Yakutat in relation to the Situk River and the head of Russell Fiord

Figure 2. Location of Hubbard Glacier in Southeast Alaska ............................................................. 5

Figure 3. Average maximum and minimum daily air temperature recorded at Yakutat, Alaska

Figure 4. Total annual precipitation recorded at Yakutat, Alaska, from 1950 to 2006 .................... 7

Figure 5. Daily average precipitation recorded at Yakutat, Alaska: 95th percentile, 50th percentile, and 5th percentile

Figure 6. Daily average discharge in the Situk River and Ophir Creek ......................................... 8

Figure 7. Estimated inflow into Russell Lake during the 2002 closure ............................................. 10

Figure 8. Russell Lake watershed .................................................................................................. 12

Figure 9. Observed and estimated inflows into Russell Lake during the 2002 closure .................. 15

Figure 10. Observed daily discharge in the Situk River and Ophir Creek, 1991-2006................... 15

Figure 11. Observed daily precipitation at Yakutat, Alaska............................................................ 16

Figure 12. Observed daily air temperature at Yakutat, Alaska ........................................................ 16

Figure 13. Estimated inflows into Russell Lake over the period of record ...................................... 17

Figure 14. Annual maximum flows in Russell Lake based on USGS regression equations and the hydrological model developed for this study .................................................................. 18

Figure 15. Discrete return LiDAR sensor and a full-waveform LiDAR system .................................20

Figure 16. Color-shaded 9.843-ft DEM of the Yakutat Forelands NASA ATM-IV LiDAR data ............ 23

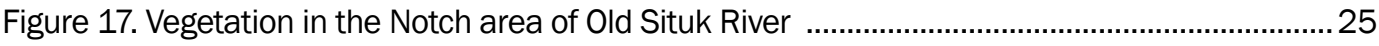

Figure 18. LiDAR data. Inset shows gaps over Situk River ................................................................. 27

Figure 19. Manning's n values for the Situk River model................................................................... 28

Figure 20. Situk River geometry model in HEC-RAS .......................................................................... 29

Figure 21. Old Situk River road crossing with culverts ....................................................................30

Figure 22. Rating curve and observed stages at Situk River gage along with HEC-RAS

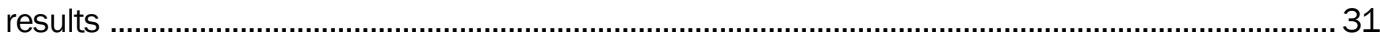

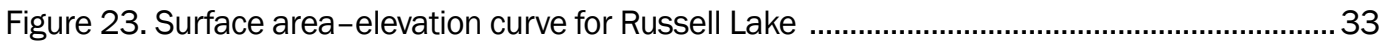

Figure 24. Outflow-elevation curve for Russell Lake for the channel with trees and without trees

Figure 25. Estimated Russell Lake daily stages for the channel with trees and without trees

Figure 26. Simulated inflows and outflows of Russell Lake.

Figure 27. Simulated outflows of Russell Lake for the channel with trees and without trees

Figure 28. Daily average Pacific Ocean surface elevation at Yakutat, Alaska . 
Figure 29. Exceedance probabilities for the Russell Lake outflow channel with trees .................... 41

Figure 30. Exceedance probabilities for the Russell Lake outflow channel with no trees .............. 42

Figure 31. Exceedance probabilities for the Situk Lake outflow ..................................................... 42

Figure 32. Exceedance probabilities for the Upper Situk River discharge ........................................ 43

Figure 33. Daily average flow in the Situk River after closure compared to existing

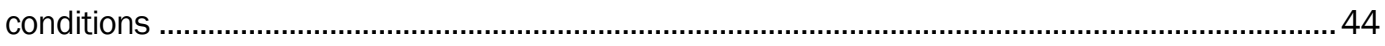

Figure 34. Daily average flow in the Situk River before closure and after closure .......................... 44

Figure 35. Flood inundation map for the case when there are no trees in the Old Situk channel

Figure 36. Flood inundation map for the case when there are trees in the Old Situk channel 47

Figure 37. Channel shear stress in the Old Situk River channel for each percentile of flow

Figure 38. Channel shear stress in the Upper and Lower Situk Rivers for each percentile of flow 49

Figure 39. Potential erosion reaches in the Old Situk River ........................................................... 49

Figure 40. Drill log of core taken in Old Situk Channel .................................................................. 51

Figure 41. Flood profiles at the Old Situk River road crossing .......................................................52

\section{Tables}

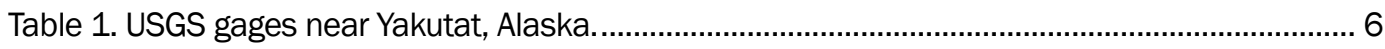

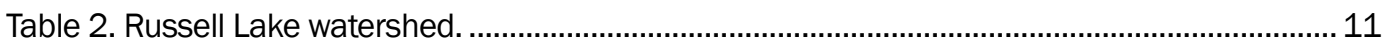

Table 3. Parameters used in USGS regression equations. ............................................................ 18

Table 4. NOAA tidal gage at Yakutat, Alaska.............................................................................. 22

Table 5. Manning's $n$ values from Table 3.1 in the HEC-RAS Reference Manual. ............................. 24

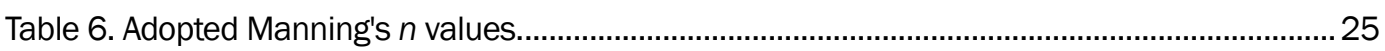

Table 7. Comparison of elevations on Yakutat runways (feet MLLW). ...............................................2

Table 8. Data used in the unsteady flow simulations for the Situk River.......................................... 37

Table 9. Flow percentiles in the Situk River system after closure. .................................................38

Table 10. Annual exceedance probabilities for the Situk River system after closure........................ 41

Table 11. Critical shear stress for bed material (after Julien 1995)............................................... 50 


\section{Preface}

This report was prepared by Dr. Steven F. Daly, Carrie Vuyovich, and David Finnegan, Remote Sensing/ GIS and Water Resources Branch, Cold Regions Research and Engineering Laboratory (CRREL), U.S. Army Engineer Research and Development Center (ERDC), Hanover, NH.

The funding for this report was provided by the Alaska District, Corps of Engineers. The authors wish to thank George Kalli, Patrick Fitzgerald, David Williams, Nathan Epps, Nathan Crane and Kenneth Eisses, all of the U.S. Army Engineering District, Alaska; Dr. Daniel Lawson, ERDC/CRREL; and the US Forest Service Yakutat Ranger District for logistical support.

The report was prepared under the general supervision of Timothy Pangburn, Chief, RS/ GIS and Water Resources Branch, CRREL; Dr. J ustin B. Berman, Chief, Research and Engineering Division, CRREL; Dr. Lance Hansen, Deputy Director, CRREL; and Dr. Robert E. Davis, Director, CRREL.

The Commander and Executive Director of ERDC is COL Kevin Wilson. The Director is Dr. J effery P. Holland. 


\section{Unit Conversion Factors}

\begin{tabular}{|l|c|l|}
\hline \multicolumn{1}{|c|}{ Multiply } & By & \multicolumn{1}{c|}{ To Obtain } \\
\hline cubic feet & 0.02831685 & cubic meters \\
\hline degrees Fahrenheit & $(\mathrm{F}-32) / 1.8$ & degrees Celsius \\
\hline feet & 0.3048 & meters \\
\hline inches & 0.0254 & meters \\
\hline miles (U.S. statute) & $1,609.347$ & meters \\
\hline pounds (force) per square foot & 47.88026 & pascals \\
\hline square miles & $2.589998 \times 10^{6}$ & square meters \\
\hline
\end{tabular}




\section{Introduction}

Hubbard Glacier, located approximately 30 miles north of the village of Yakutat, Alaska, has advanced twice in recent history $(1986,2002)$ to create an ice and moraine dam at Gilbert Point, turning Russell Fiord into Russell Lake (Fig. 1). Should the lake level rise above an elevation of approximately $137.2 \mathrm{ft}$ Mean Lower Low Water Datum (MLLW; mean sea level is $5.279 \mathrm{ft}$ above MLLW), it would spill through the "Notch" area of the southern terminal moraine and flow into the historical channel of the Old Situk River and then into the Situk River. The Situk River is approximately 7.8 miles east of Yakutat and is one of the most productive rivers in southeast Alaska (Alaska Department of Fish and Game 2009). The Situk River provides a large portion of the economy of Yakutat. It is estimated that $85 \%$ of the local commercial fishing and $82 \%$ of the local sport fish economies are derived from the Situk River. Local businesses such as lodges, hotels, bed and breakfasts, restaurants, guide services, and retail businesses depend on these resources as well (Kalli 2005). If Russell Fiord became blocked for a significant period of time, the Russell Lake discharge into the Situk would significantly exceed the capacity of the Situk River channel and would disrupt the river's fisheries and potentially threaten the the tourism and economy of Yakutat as well as Yakutat Airport.

It is not possible to quantify the probability of closure of Russell Fiord by Hubbard Glacier for an extended time with any certainty. However, given the more-or-less continuous advance of the glacier since 1895, it seems likely that that this probability is significant. Therefore, this report looks beyond the closure of Russell Fiord to describe the likely hydrology of the Situk River once a sustained closure has occurred. 


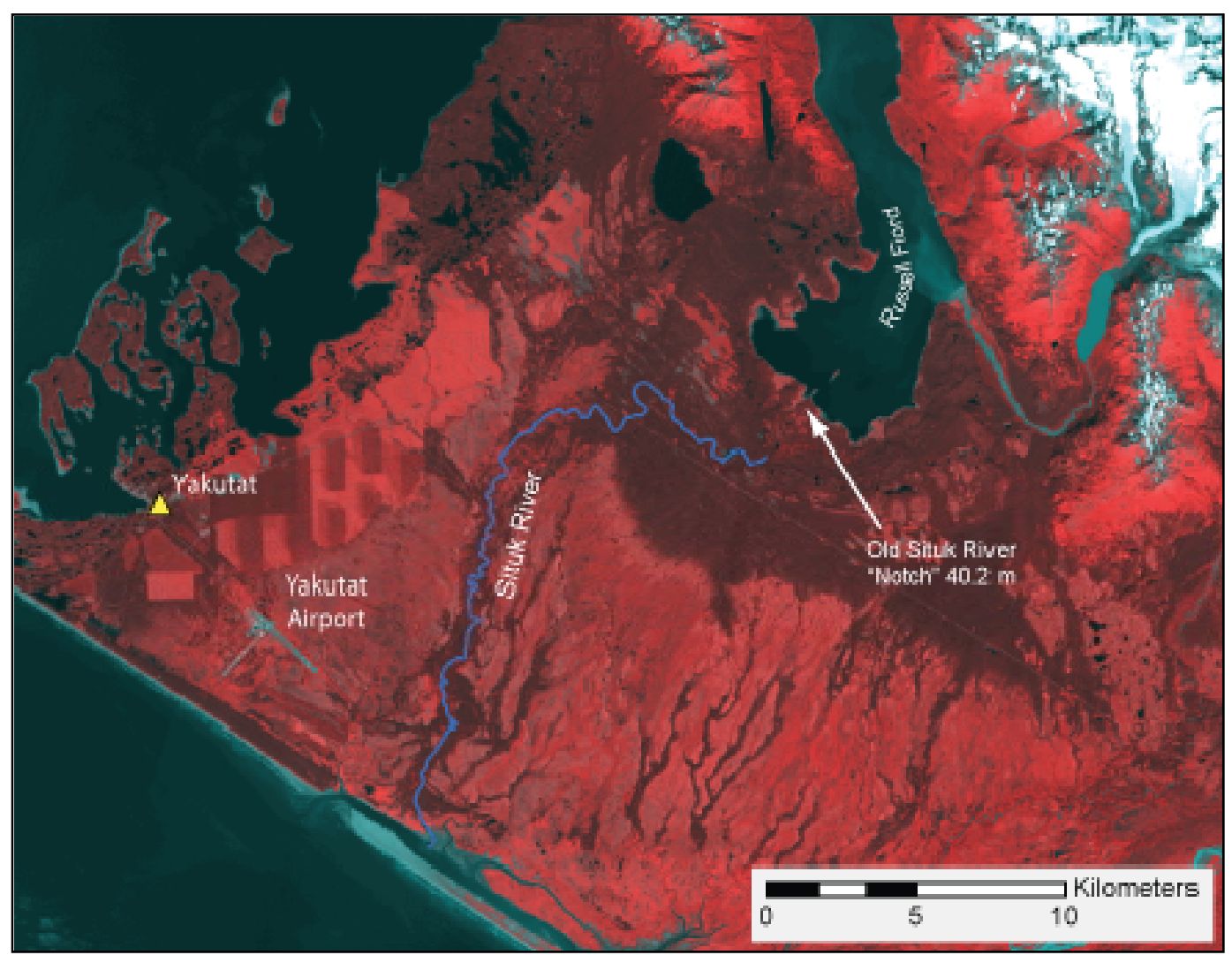

Figure 1. Town of Yakutat in relation to the Situk River and the head of Russell Fiord.

The first effect of a sustained closure would be to turn Russell Fiord into Russell Lake, a lake with no immediate outlet. The lake level would immediately begin to rise as flow entered it from the surrounding watershed. A hydrological model was developed to estimate the inflows into Russell Lake and is described in this report. Once the water level of Russell Lake has risen approximately $137.2 \mathrm{ft}$ above MLLW, the inflows into Russell Lake would spill out through the Notch area and into the Situk River system. In effect, the drainage area of the Situk River would increase over 20 times, with a corresponding increase in flow. This increase in flow would significantly affect almost every aspect of the Situk River.

In the model, the inflows into Russell Lake were routed through the lake to determine the Russell Lake outflows into the Situk River. A HEC-RAS onedimensional flow model (U.S. Army Corps of Engineers 2002) was developed to estimate the levels and flows of the Situk River system, including the Old Situk, Upper Situk, and Lower Situk rivers. The channel geometry was based on an extensive LiDAR survey that was conducted for the Situk River watershed using NASA's Airborne Topographic Mapper in August and September 2005. The LiDAR data were processed and analyzed to 
provide cross sections for the HEC-RAS model. The levels and flows in the Situk River system were simulated over 15 years using the estimated outflows from Russell Lake to determine the statistics of the hydrology of the Situk River system. A series of steady flow profiles were then determined, with the discharges and boundary conditions based on the results of the 15-year simulation. These profiles were used to develop inundation maps and investigate potential channel erosion, the effects on the Old Situk River road crossing and Situk Lake (the upstream source of the Situk River), and the potential impacts of logjams and channel migration. 


\section{Background}

\section{Hubbard Glacier Closure}

Hubbard Glacier is the largest non-polar tidewater glacier in the world and the largest tidewater glacier in North America. It encompasses an area of 1350 miles$^{2}$ and flows from the flanks of Mt. Logan (19,550 ft) in the Wrangell- St. Elias Mountains (Canada) 72 miles south to sea level, where its terminus widens to 7.2 miles and discharges into Disenchantment Bay and Russell Fiord.

Hubbard Glacier's history differs from that of other Alaskan glaciers. During the little Ice Age, when most glaciers in the vicinity had advanced to their maximum positions, Hubbard was engaged in a large-scale retreat (Barclay et al. 2001). More recently, it has advanced 1.5 miles since 1895 (Trabant et al. 2003). Over the past 50 years, most glaciers in southeast Alaska have been thinning and retreating at record rates (Echelmeyer et al. 1996; Arendt et al. 2002; Larsen et al. 2007), while Hubbard Glacier advanced an estimated 90- $112 \mathrm{ft} \mathrm{yr}^{-1}$ into Disenchantment Bay and Russell Fiord. Between 1986 and 2002 it has averaged $90 \mathrm{ft} \mathrm{yr}^{-1}$ (Trabant et al. 2003). The terminus position has been known to vary by as much as $985 \mathrm{ft}$ annually (Finnegan et al. 2007).

In 1986 and 2002, Hubbard Glacier advanced far enough to isolate Russell Fiord from Disenchantment Bay, forming an ice/ moraine sediment dam at Gilbert Point, resulting in 40-mile-long Russell Lake. These closure events ended when the moraine and ice dams isolating Russell Fiord from tidewater failed. After failure of the moraines, the temporary lakes drained, in dramatic fashion, into Disenchantment Bay.

If a permanent closure forced the lake level to rise above an elevation of approximately $137.2 \mathrm{ft} \mathrm{MLLW}$, the outflow would spill through the historical channel of the Old Situk Creek and then into the Situk River, both located southwest of the southern end of Russell Fiord (Fig.2). The Russell Lake discharge could greatly exceed the capacity of the Situk River and significantly disrupt the river's fisheries and the economic base for the community of Yakutat, along with flooding critical infrastructure. 


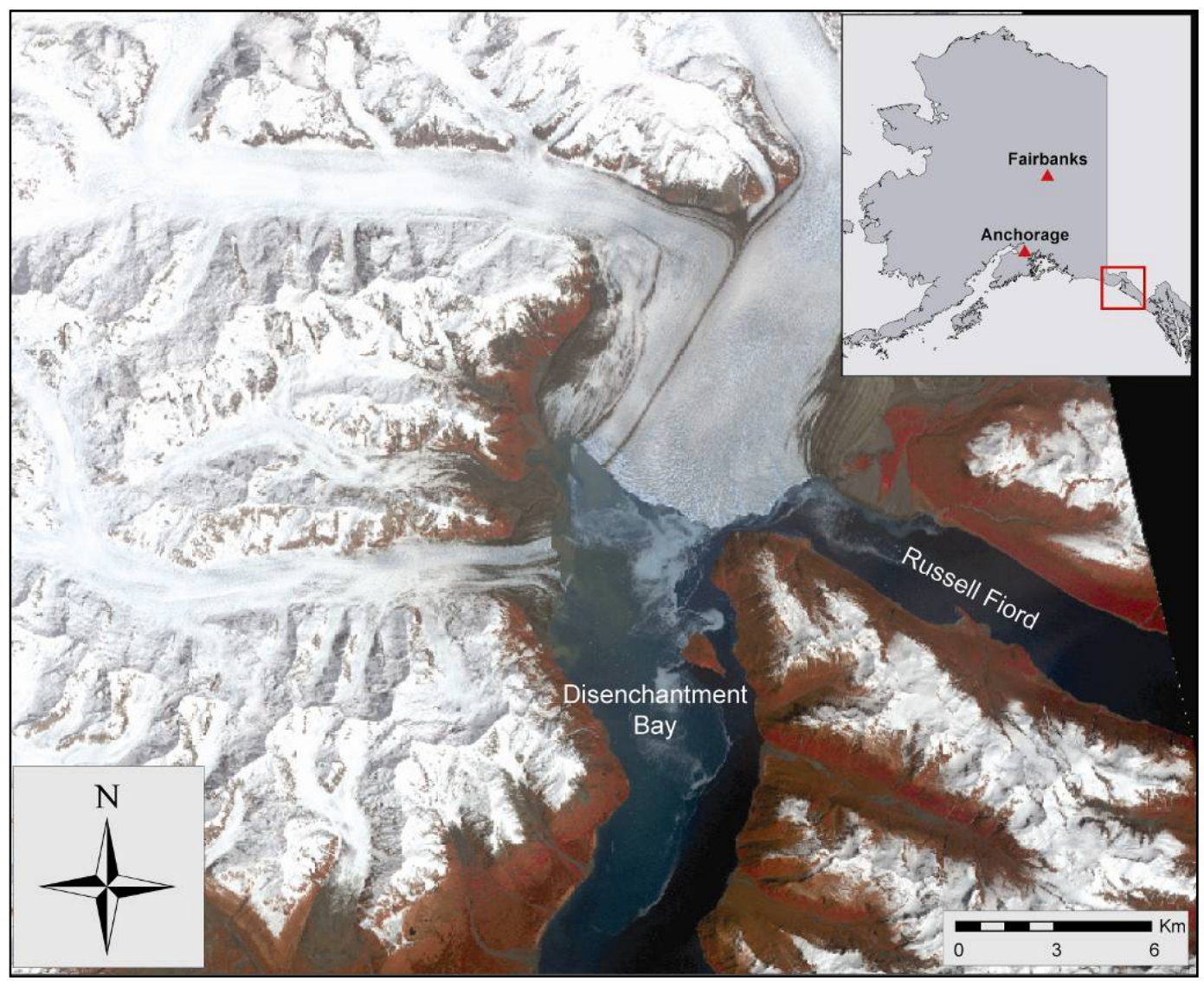

Figure 2. Location of Hubbard Glacier in Southeast Alaska. The 15-m/pixel RGB false color composite satellite image was acquired by NASA's ASTER sensor on 12 June 2003.

\section{Situk River Watershed}

The area of Yakutat and the Situk River watershed has a maritime climate characterized by relatively mild, often rainy weather. Summer temperatures range from the upper $40 \mathrm{~s}$ to $60^{\circ} \mathrm{F}$; winter temperatures are from the lower 20 s to $40^{\circ} \mathrm{F}$ (Fig. 3). The Yakutat average annual total precipitation, 132 in. per year, is among the heaviest in the state. The maximum annual total precipitation, over 250 in., was recorded in 1987 (Fig. 4). The maximum precipitation generally falls in late September and October and the minimum in J une of each year (Fig. 5). The flows in the gaged watersheds of the Situk River and Ophir Creek (Table 1) show a pattern similar to that of precipitation, with maximum flows in late September or early October and minimum in the summer months (Fig. 6).

The vegetation in the Situk River watershed is described as follows: "Vegetation on the lowland landscape of the foreland is characterized by marsh and muskeg species typical of poorly drained soils in Southeast Alaska. 
The wetland species are primarily sphagnum moss, sedges, and heathers. On drier areas, willows, cottonwoods, alders, devils-club, salmonberry, blueberry, copper bush, hellebore, ferns, skunk cabbage and huckleberry, grow over a carpet of mosses and liverworts. A dense overstory of Sitka spruce and/ or western hemlock grows on the timbered areas. The sand dunes that front the ocean beach include a plant community unique to Southeast Alaska. Common plants include fireweed, lousewort, paintbrush, lupine, and wild strawberries. Uncommon plants found on the dunes include species of the Atriplex, Lupimachia and Saussurea genera" (U.S. Army Corps of Engineers 2005).

Table 1. USGS gages near Yakutat, Alaska.

\begin{tabular}{|l|c|c|c|}
\hline \multicolumn{1}{|c|}{ Gage } & $\begin{array}{c}\text { Drainage Area } \\
\left(\mathrm{mile}^{2}\right)\end{array}$ & Start of Data & Most Recent \\
\hline 15129500 Situk R near Yakutat AK & 36.0 & $1988-05-08$ & $2008-01-13$ \\
\hline 5129600 Ophir Creek near Yakutat AK & 2.5 & $1991-10-02$ & $2007-09-30$ \\
\hline 15129510 Old Situk R near Yakutat AK & 4.78 & $2003-06-28$ & $2006-09-30$ \\
\hline
\end{tabular}

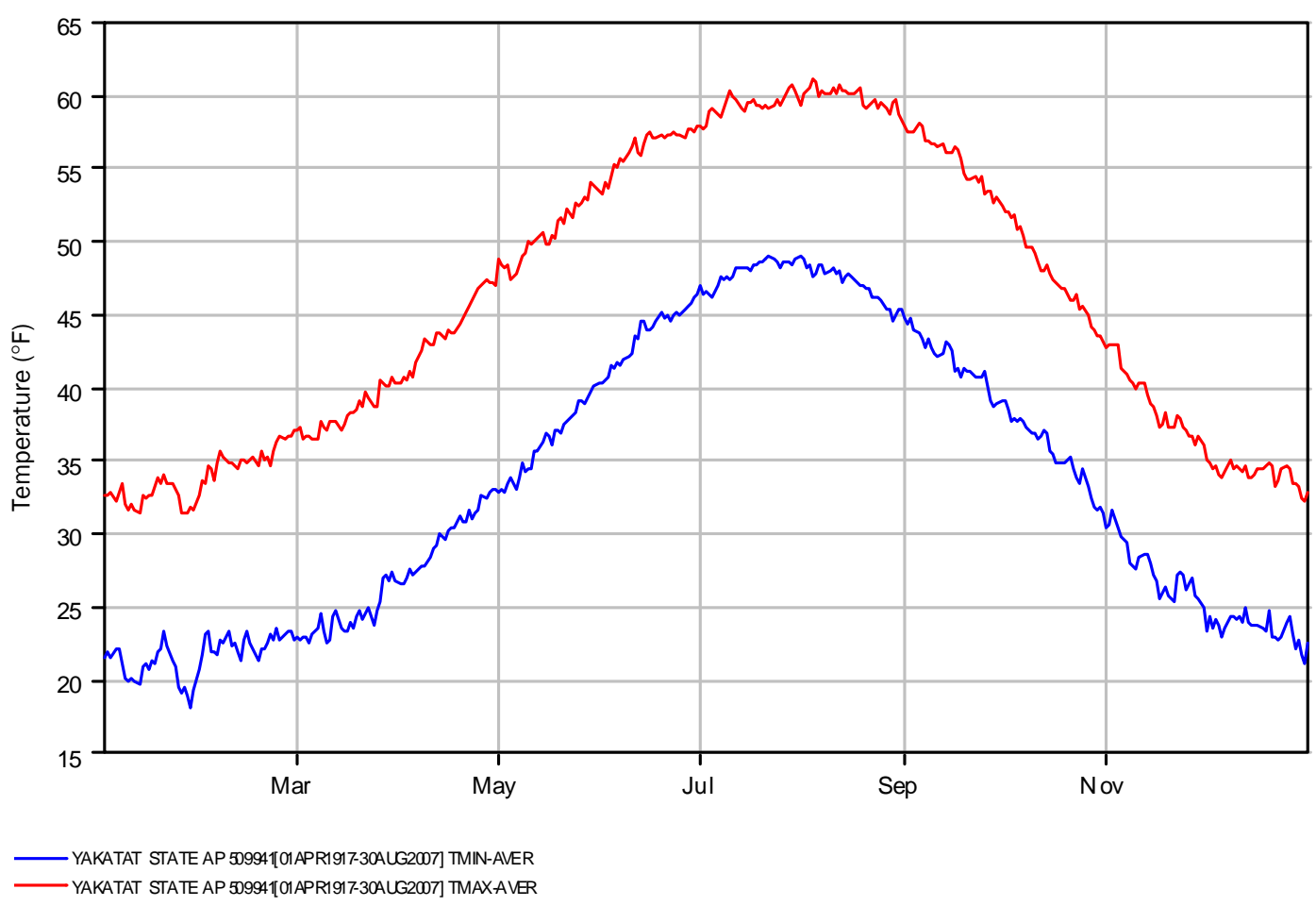

Figure 3. Average maximum and minimum daily air temperatures recorded at Yakutat, Alaska. 


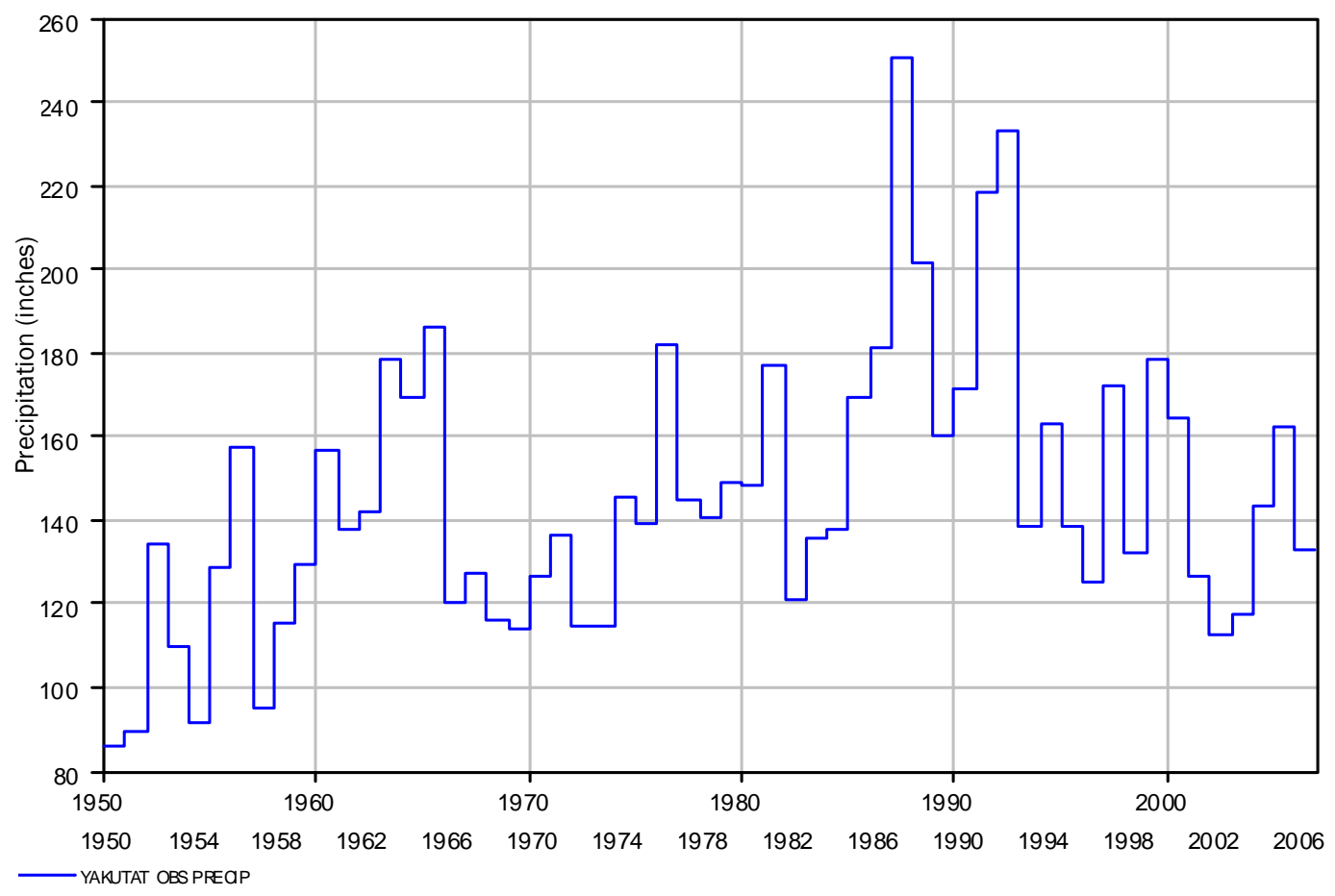

Figure 4. Total annual precipitation recorded at Yakutat, Alaska, from 1950 to 2006.

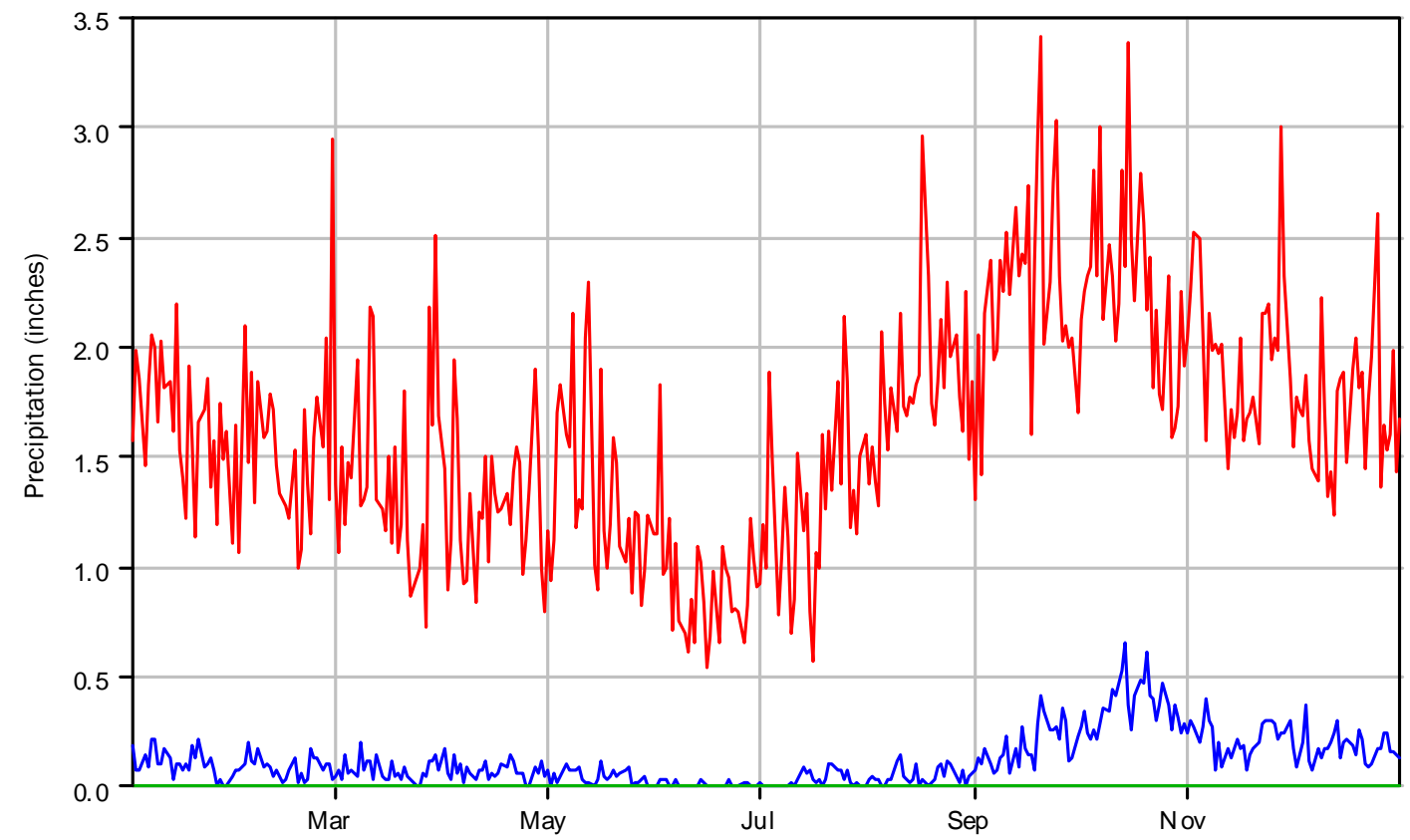

Figure 5. Daily average precipitation recorded at Yakutat, Alaska: 95th percentile (red), 50th percentile (blue). 


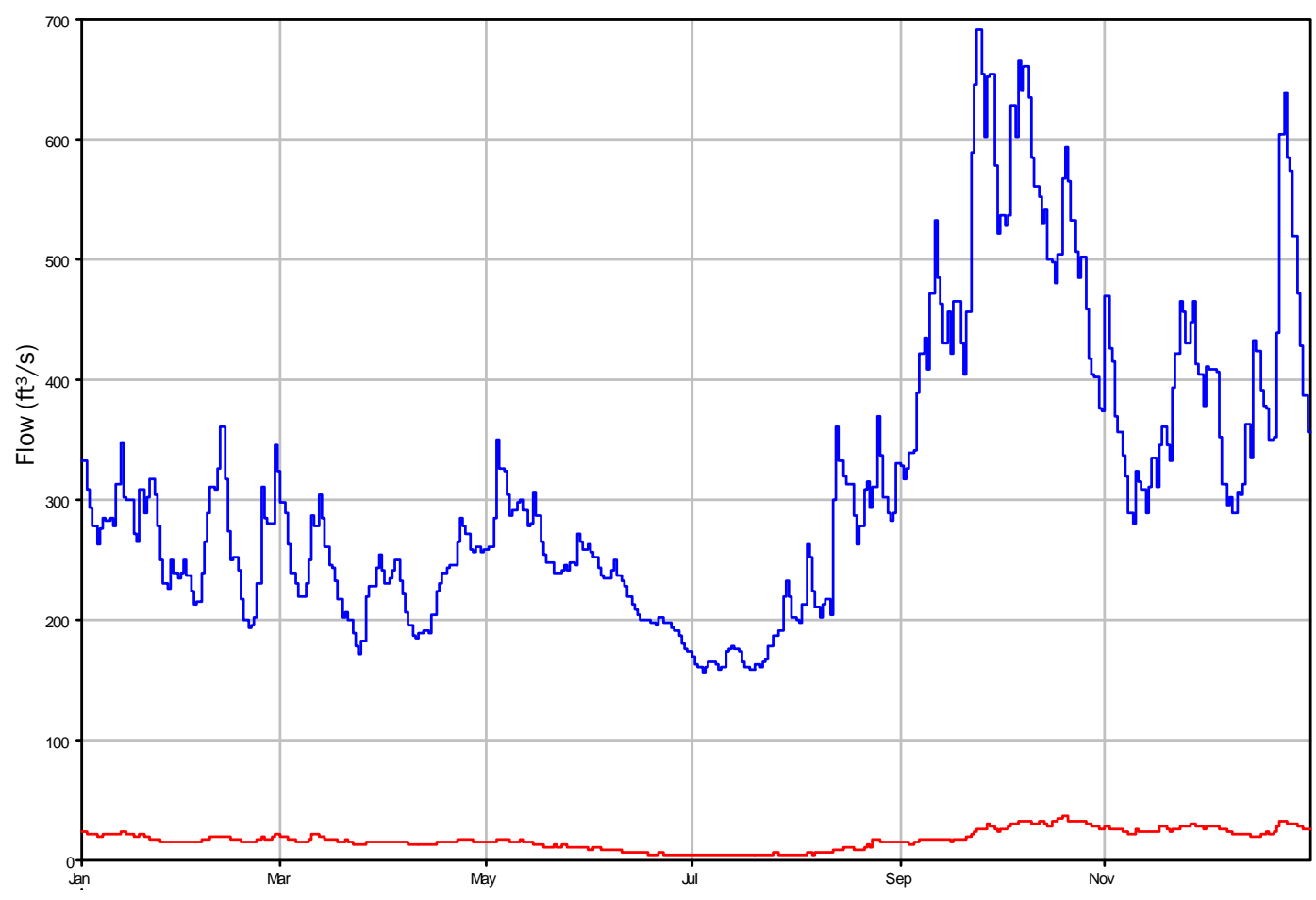

Figure 6. Daily average discharge in the Situk River (blue) and Ophir Creek (red). 


\section{Russell Lake Hydrology Following Closure of Russell Fiord}

Estimates of the inflows into Russell Lake must be based on hydrological models because river gages have never been located in the watershed of Russell Lake. This lack of gages is understandable, given the watershed's remote location and absence of habitation. The inflows into Russell Lake were estimated in a previous study (Neal 2004) using two approaches. The first was based on a simple hydrological model using the observed flows of the Situk River and Ophir Creek during the closure event of 2002. The Russell Lake water surface elevations seen during the closure event were used to estimate the inflows during this period (roughly mid-J une through mid-August 2002). The inflows could be estimated for each day of this period by equating the inflows to the change in storage volume with time. The calculated inflow rate during this period is shown in Figure 7. The Situk River and Ophir Creek are not in the watershed of Russell Lake, but the observed flow in each of these watercourses was combined in a regression equation that was found to reasonably reproduce the observed inflow during 2002.

$$
\text { QRussell }=16003+2798 \text { (Qophir) }-23.806 \text { (QSituk) }
$$

where QRussell $=$ inflowinto Russell Lake

Qophir = daily average flow in Ophir Creek

Qsituk = daily average flow in the Situk River.

The second approach was to estimate the inflow into Russell Lake using the regression equations developed for ungaged basins in Alaska by the USGS (Curran et al. 2003). These regression equations can be used to estimate the magnitude of flows with an annual return period of 2 to 500 years based on watershed parameters of area, precipitation, and J anuary temperature. Equation 1 was used to estimate the annual maximum Russell Lake inflow during the period when discharges had been observed on both the Ophir Creek and the Situk River: 1991-2006. This series of annual maximums could then be compared to the flows estimated using the USGS regression equations. Only rough agreement was found between the two approaches. 


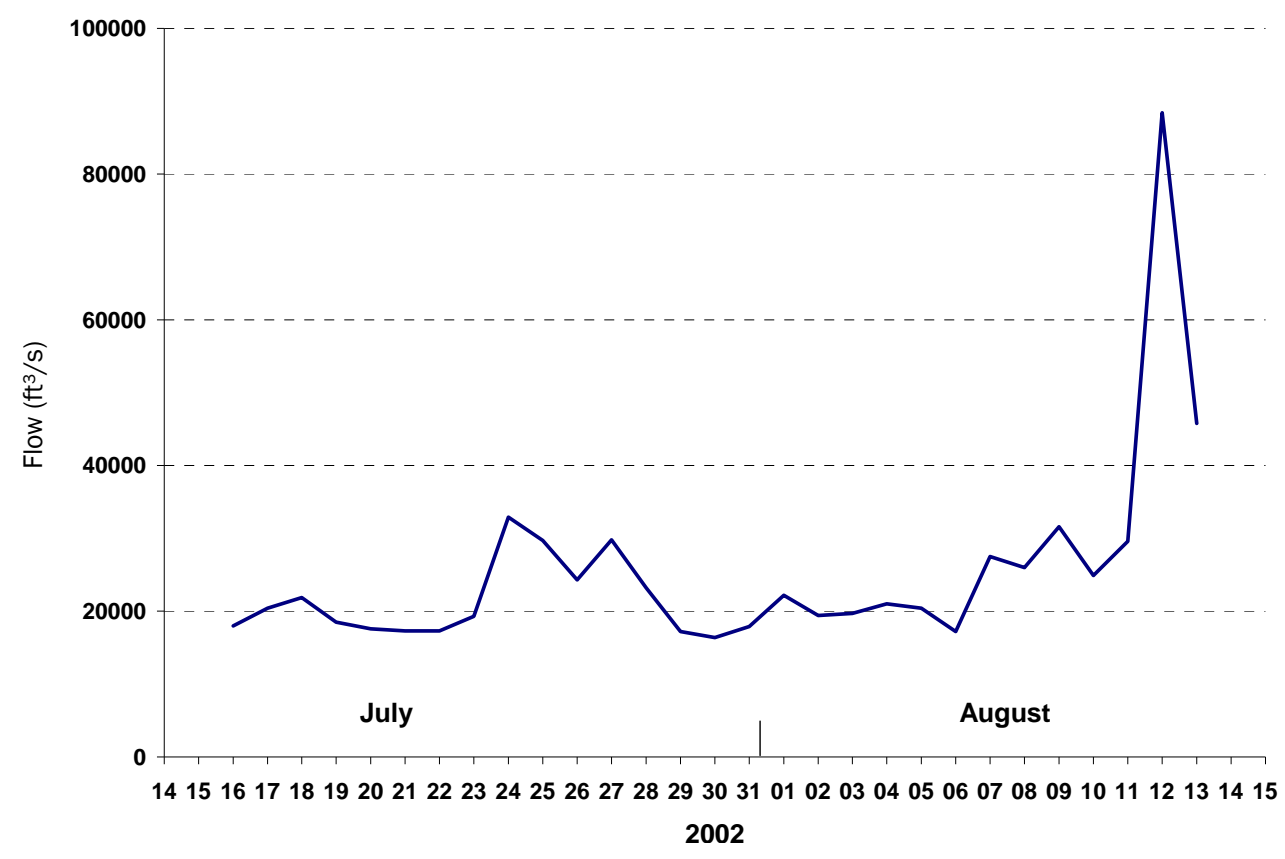

Figure 7. Estimated inflow into Russell Lake during the 2002 closure (Neal 2009).

There are two main problems with using eq 1 to estimate the inflows into Russell Lake. First, the combined area of the gaged portions of Ophir Creek and the Situk River is much smaller than the estimated area of the Russell Lake watershed. More importantly, both Ophir Creek and the Situk River are small coastal watersheds where the runoff results exclusively from coastal precipitation. Coastal precipitation typically peaks during October and November, and the runoff from both watersheds also typically peaks during these months. However, the watershed of Russell Lake is approximately $45 \%$ glaciated. The runoff from glaciated watersheds typically peaks in the summer, when heat input into the accumulated snow and ice is at a maximum. Estimating daily inflows into Russell Lake by applying eq 1 will result in hydrographs that have the basic form of the annual flow hydrographs of Ophir Creek and the Situk River, with peaks in late autumn. Neal (2004) recognized this difficulty with eq 1; he used it to estimate flows only during the summer months. 
Table 2. Russell Lake watershed.

\begin{tabular}{|l|c|c|}
\hline Location & $\begin{array}{c}\text { Area } \\
\text { (miles }^{2} \text { ) }\end{array}$ & $\begin{array}{l}\text { Percentage of Total } \\
\text { Watershed }\end{array}$ \\
\hline Watershed & 729 & 100 \\
\hline Russell Lake & 77 & 10 \\
\hline Glaciers & 331 & 45 \\
\hline Unglaciated & 321 & 45 \\
\hline
\end{tabular}

We developed a new watershed model that combines runoff from the three types of area that contribute flow in the Russell Lake watershed: runoff from the unglaciated portion of the watershed, direct precipitation on the surface of Russell Lake, and runoff from the glaciated portion of the watershed. This can be represented as

$$
\mathrm{Q}_{\mathrm{i} \text { total }}=\mathrm{Q}_{\mathrm{i} \text { ug_Russell }}+\mathrm{Q}_{\mathrm{i} \text { rain }}+\mathrm{Q}_{\mathrm{i} \text { glaciated }}
$$

where $\mathrm{Q}_{\mathrm{i} \text { ug_Russell }}=$ estimated inflow into Russell Lake from unglaciated area on day $i$

$$
\mathrm{Q}_{\mathrm{i} \text { rain }}=\begin{aligned}
& \text { inflow into Russell Lake from rainfall on the lake itself } \\
& \text { on day } \mathrm{i}
\end{aligned}
$$

$\mathrm{Q}_{\text {i glaciated }}=$ daily average runoff from the glaciated area on day $\mathrm{i}$ (Fig. 8).

Runoff from the unglaciated portion of the watershed (roughly 321 miles $^{2}$ when the surface of Russell Lake is at mean sea level) was estimated by assuming that this runoff would respond to the coastal precipitation in a manner similar to observed runoff from Ophir Creek and the Situk River. The following procedure was used to estimate the runoff from this portion of the watershed. First, we estimated the daily average discharge per square mile for Ophir Creek and the Situk River. The weighted average of the two estimates was then used to estimate the flow out of the unglaciated portion of the Russell Lake:

$$
\mathrm{Q}_{\mathrm{i}_{\text {ug_Russell }}}=\mathrm{A}_{\text {ugR }} \frac{\mathrm{A}_{\text {Ophir }} \mathrm{q}_{\mathrm{isqMi}-\text { Ophir }}+\mathrm{A}_{\text {Situk }} \mathrm{q}_{\mathrm{isqMi} \text {-Situk }}}{\left(\mathrm{A}_{\text {Ophir }}+\mathrm{A}_{\text {Situk }}\right)}
$$

where $A_{u g R}=$ unglaciated area of the Russell Lake watershed (321 square miles)

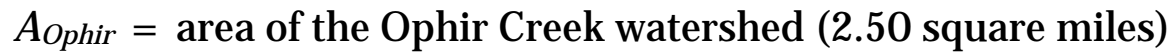


$\mathrm{q}_{\mathrm{i} \text { sqMi-Ophir }}=$ average discharge per square mile for Ophir Creek on day i

$A_{\text {Situk }}=$ area of the Situk River watershed $\left(36\right.$ mile $\left.^{2}\right)$

$\mathrm{q}_{\mathrm{i} \text { sqMi-Situk }}=$ average discharge per square mile for Situk Creek on day $\mathrm{i}$.
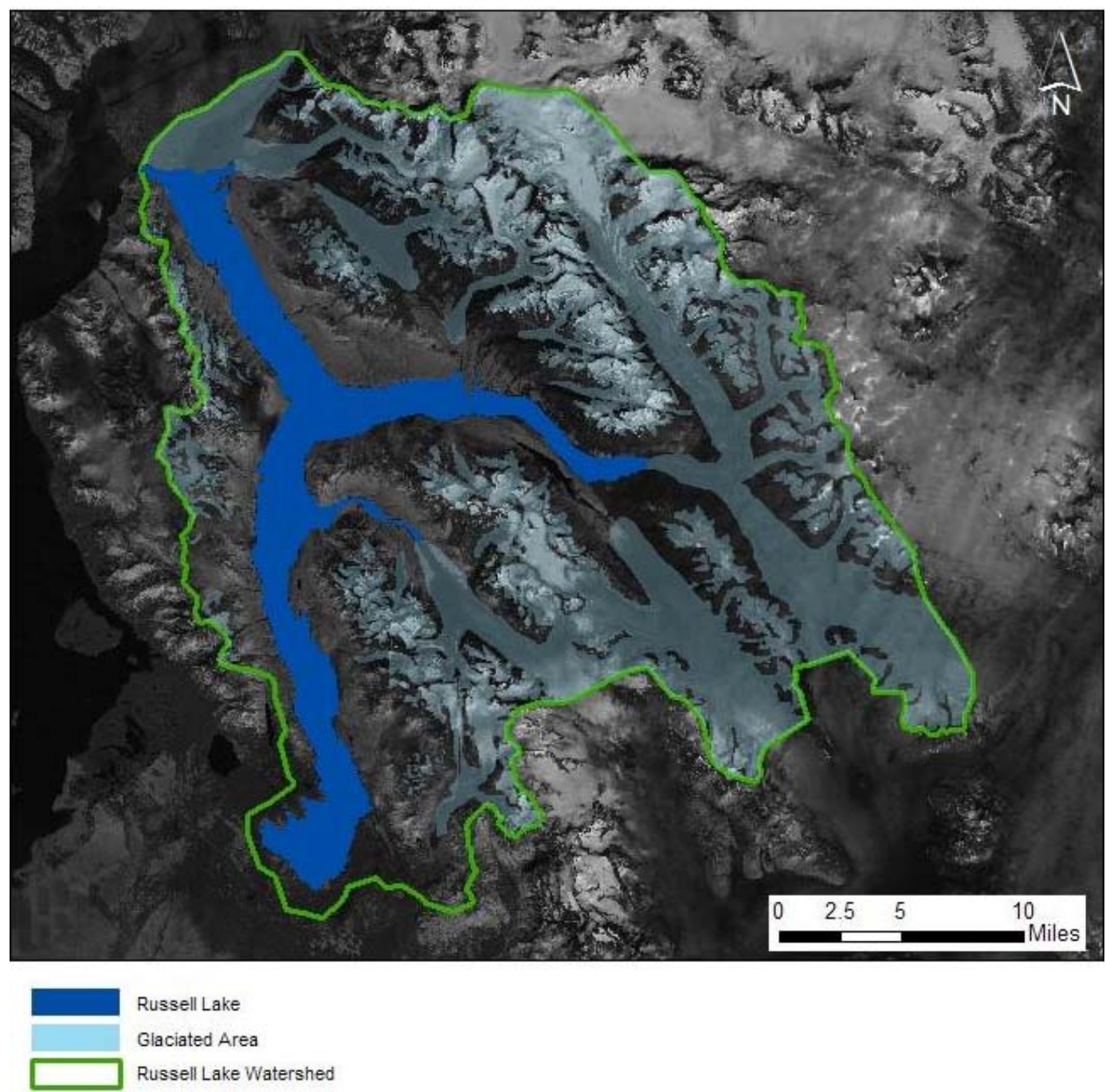

Russell Lake

Glaciated Area

Russell Lake Watershed

Figure 8. Russell Lake watershed.

Next, the inflow into Russell Lake that occurs directly because of precipitation on the lake (roughly 77 mile $^{2}$ when the surface of the Lake is at mean sea level) was estimated as

$$
\mathrm{Q}_{\mathrm{i} \text { Rain }}=\frac{\mathrm{P}_{\mathrm{i}} \mathrm{A}_{\mathrm{L} . \text { Russell }}}{100(12 \mathrm{in} . / \mathrm{ft})(3600 \mathrm{~s} / \mathrm{hr})(24 \mathrm{hr} / \text { day })}
$$

where $\quad P_{i}=$ precipitation in hundredths of inches per day on day $i$

$\mathrm{A}_{\mathrm{L} . \text { Russell }}=$ area of Russell Lake in $\mathrm{ft}^{2}$. 
The rainfall used was recorded at Yakutat Airport.

The runoff from the glaciated portion of the watershed (roughly 331 mile $^{2}$ when the surface of Russell Lake is at mean sea level) was modeled:

when $\mathrm{T}_{\mathrm{i} \text { air }}>\mathrm{T}_{\mathrm{m}}$ :

$$
\mathrm{Q}_{\mathrm{i} \text { glaciated }}=\mathrm{M}_{\mathrm{fi}}\left(\mathrm{T}_{\mathrm{i} \text { air }}-\mathrm{T}_{\mathrm{m}}\right) \mathrm{A}_{\mathrm{gR}}\left(\frac{1}{(12 \mathrm{in} . / \mathrm{ft})(3600 \mathrm{~s} / \mathrm{hr})(24 \mathrm{hr} / \text { day })}\right)
$$

when

$$
\begin{aligned}
\mathrm{T}_{\mathrm{i} \text { air }} & \leq \mathrm{T}_{\mathrm{m}} \\
\mathrm{Q}_{\text {i glaciated }} & =0.0
\end{aligned}
$$

where $\mathrm{M}_{\mathrm{fi}}=$ melt factor (in. $/{ }^{\circ} \mathrm{F}$ day) on day $\mathrm{i}$

$\mathrm{T}_{\mathrm{m}}=$ base temperature $\left(32^{\circ} \mathrm{F}\right)$

$\mathrm{T}_{\mathrm{i} \text { air }}=$ daily average air temperature on day $\mathrm{i}$

$\mathrm{A}_{\mathrm{gR}}=$ glaciated area of the Russell Lake watershed in square feet (approximately 330 mile²).

The daily average air temperature used was recorded at Yakutat Airport. Note that $\mathrm{Q}_{\mathrm{i}}$ glaciated will be zero when $\mathrm{T}_{\text {air }}$ is less than or equal to the base temperature.

The values of $\mathrm{M}_{\mathrm{f} i}$ were estimated using the daily inflow values during the closure event of 2002. The combined daily total of $\mathrm{Q}_{\mathrm{i}}$ rain and $\mathrm{Q}_{\mathrm{i}}$ ug_Russell were subtracted from the estimated inflow into Russell Lake for each day during the 2002 closure event to estimate the flow from the glaciated por-

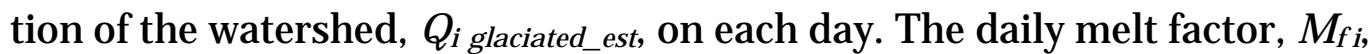
and the average melt factor for that period, $\mathrm{M}_{\mathrm{f}}$ avg, were then estimated as

$$
M_{f i}=\frac{Q_{i_{\text {glaciated_est }}}}{\left(T_{m}-T_{\text {iair }}\right)} \frac{[(12 \text { in./ft)(3600 s/hr) (24 hr/day) }]}{A_{g R}}
$$

where $\mathrm{M}_{\mathrm{fi}}$ is the melt factor on day i. Equation 6 provides a melt factor for each day between 16 J uly 2002 and 13 August 2002. The average melt factor over this period was found to be $0.108 \mathrm{in} . /{ }^{\circ} \mathrm{F}$-day, or $4.95 \mathrm{~mm} /{ }^{\circ} \mathrm{C}$-day. This result compares well with published values (Hock 2003). 
Given the intense precipitation rates in this area of Alaska, we decided to investigate $\mathrm{M}_{\mathrm{fi}}$ as a function of the daily precipitation and wind speed (U.S. Army Corps of Engineers 1998). This was done by comparing the time series of $\mathrm{M}_{\mathrm{fi}}$ with the daily time series of wind speed and precipitation. Wind speed was not found to be significant, but precipitation was found to influence $\mathrm{M}_{\mathrm{fi}}$. The melt factor was then restated as a function of the daily precipitation in hundredths of inches per day, $\mathrm{P}_{\mathrm{i}}$ :

$$
\mathrm{M}_{\mathrm{fi}}\left(\mathrm{P}_{\mathrm{i}}\right)=0.088+0.000421 \mathrm{P}_{\mathrm{i}}
$$

where $P_{i}$ is the precipitation in hundredths of inches on day $i$. This is the melt factor formula used in the hydrological model of the Russell Lake watershed.

The result of applying eq 2 is shown in Figure 9. This hydrological model matches the estimated inflows reasonably well. This model also has the advantage that it estimates the runoff from the glaciated and unglaciated areas separately. This approach shows that the annual peak runoff from the unglaciated areas tends to occur in autumn, and the annual peak from the glaciated areas tends to happen in mid-summer. This allows the hydrological model to be used year-round and applied over the period of record of the data, 1October 1991- 30 September 2006. Figures 10-12 use these data. The estimated daily inflows into Russell Lake over this period are shown in Figure 13. 


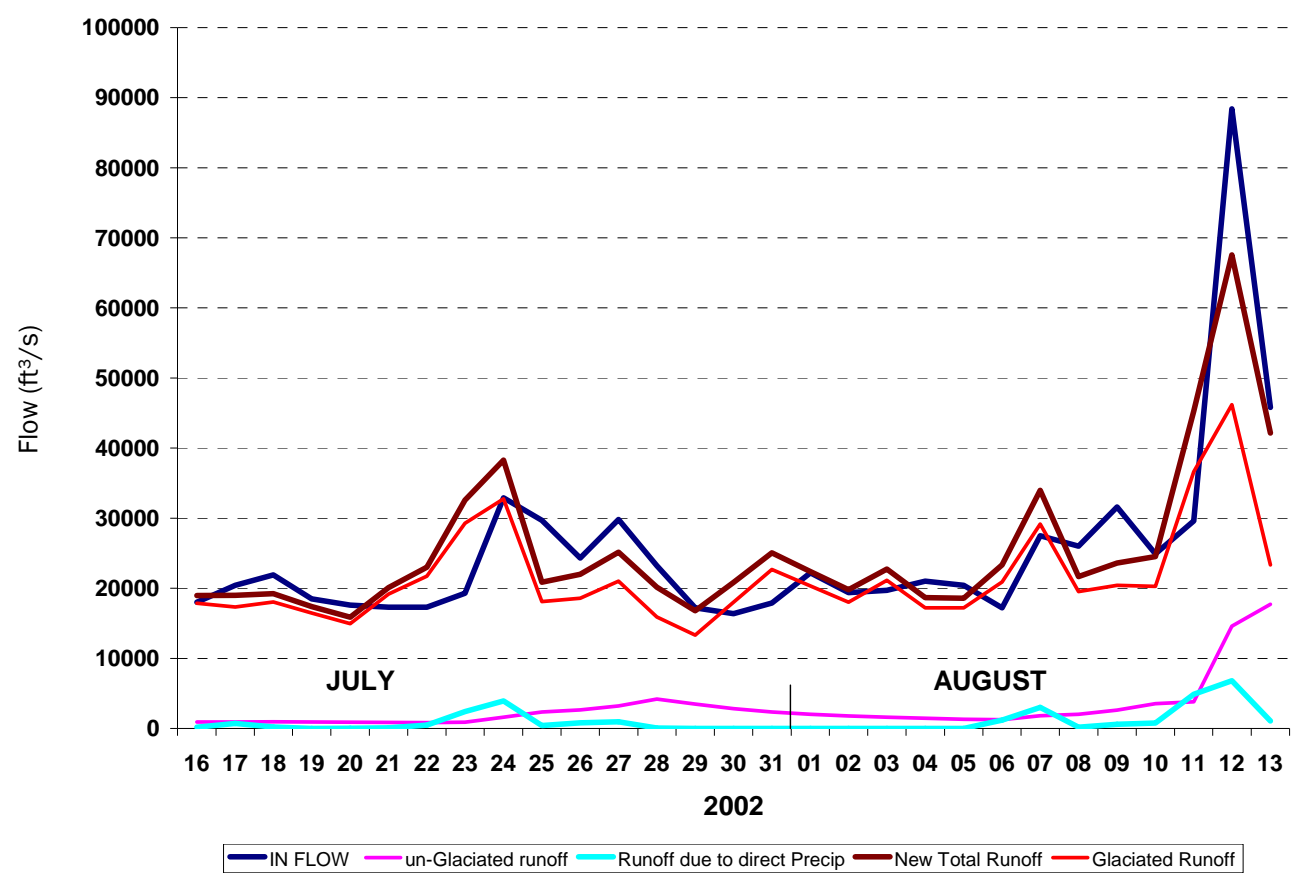

Figure 9. Observed and estimated inflows into Russell Lake during the 2002 closure.

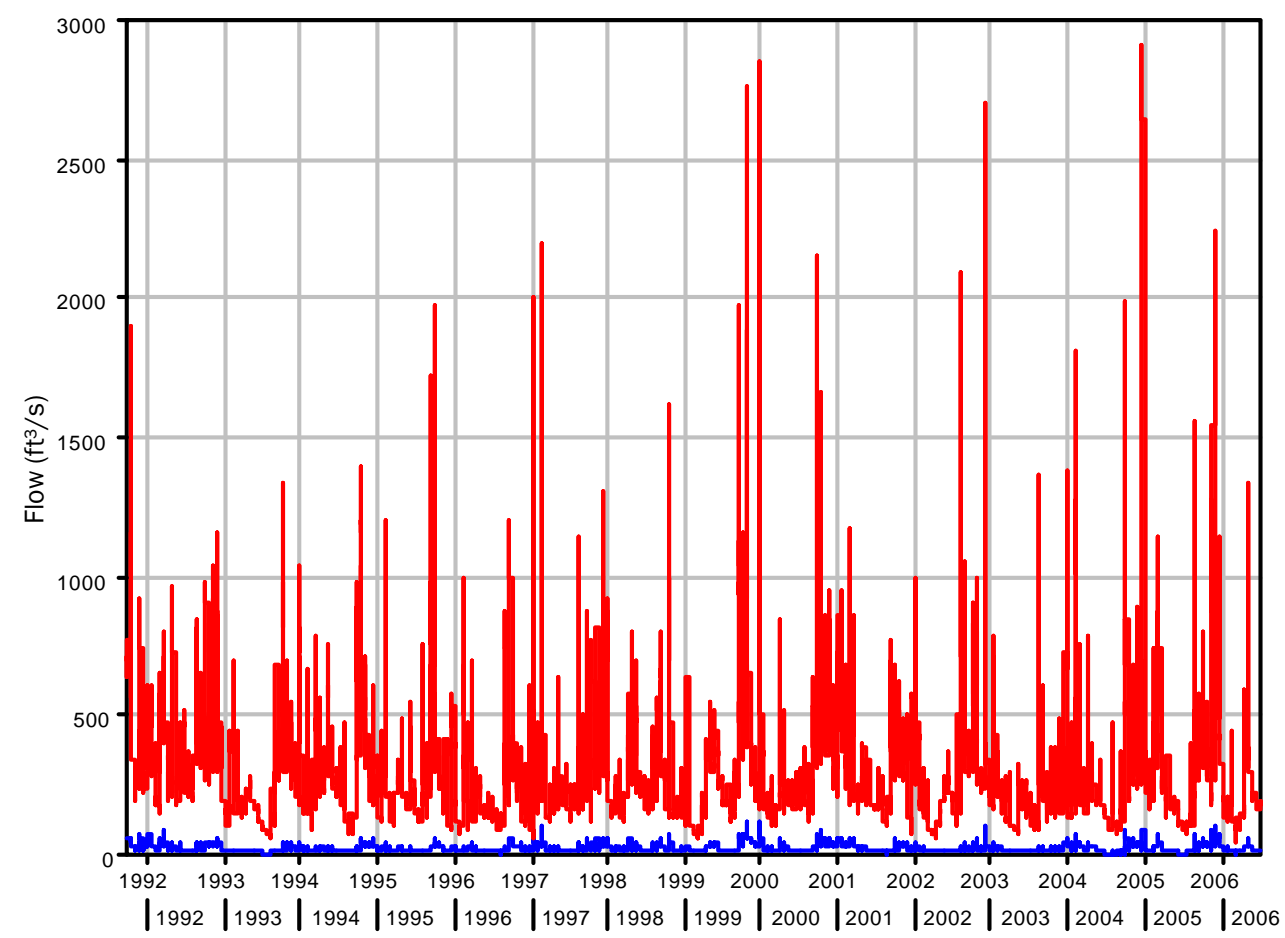

Figure 10. Observed daily discharge in the Situk River (red) and Ophir Creek (blue), 1991-2006. 


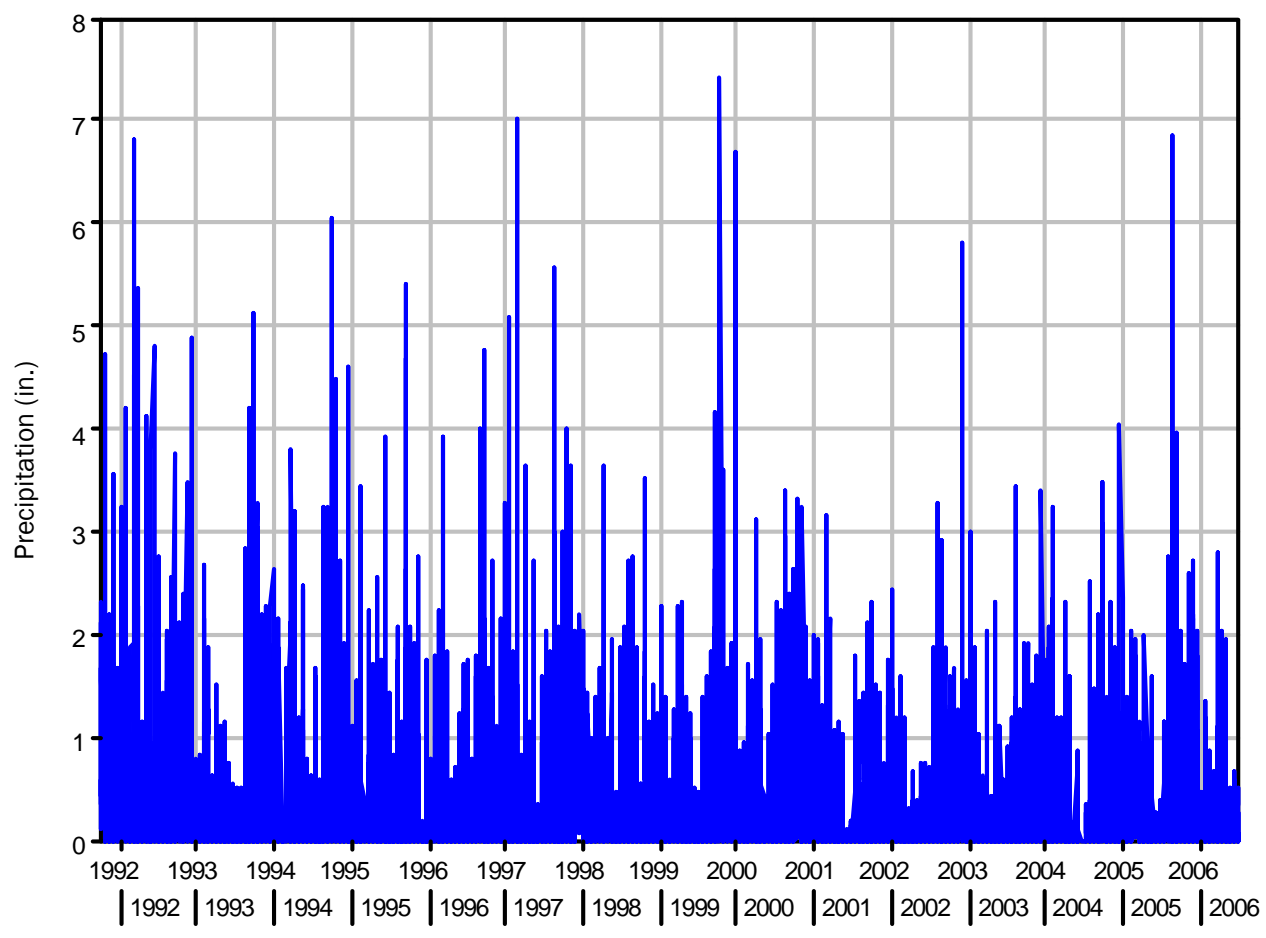

Figure 11. Observed daily precipitation at Yakutat, Alaska.

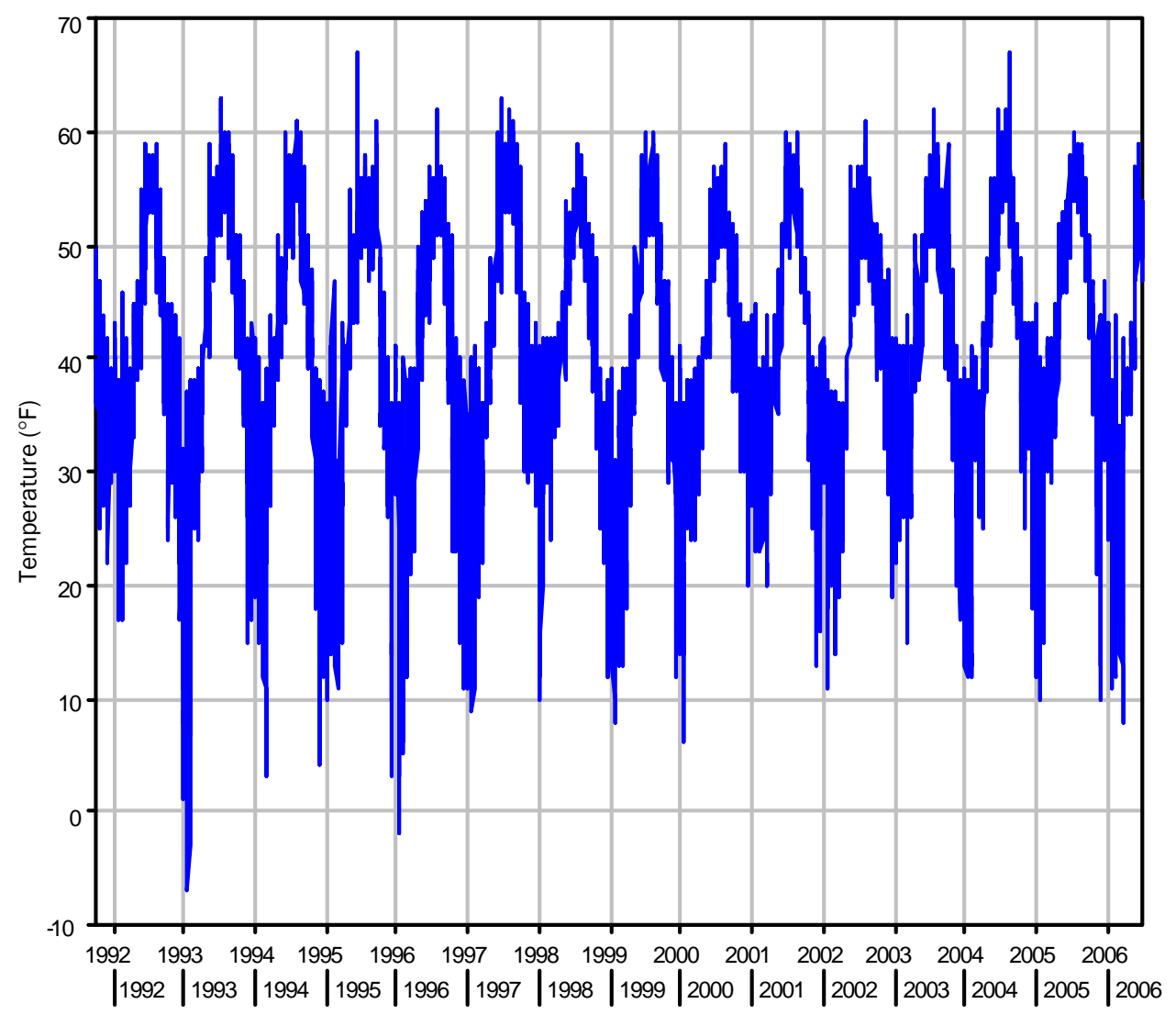

Figure 12. Observed daily air temperature at Yakutat, Alaska $\left({ }^{\circ} \mathrm{F}\right)$. 


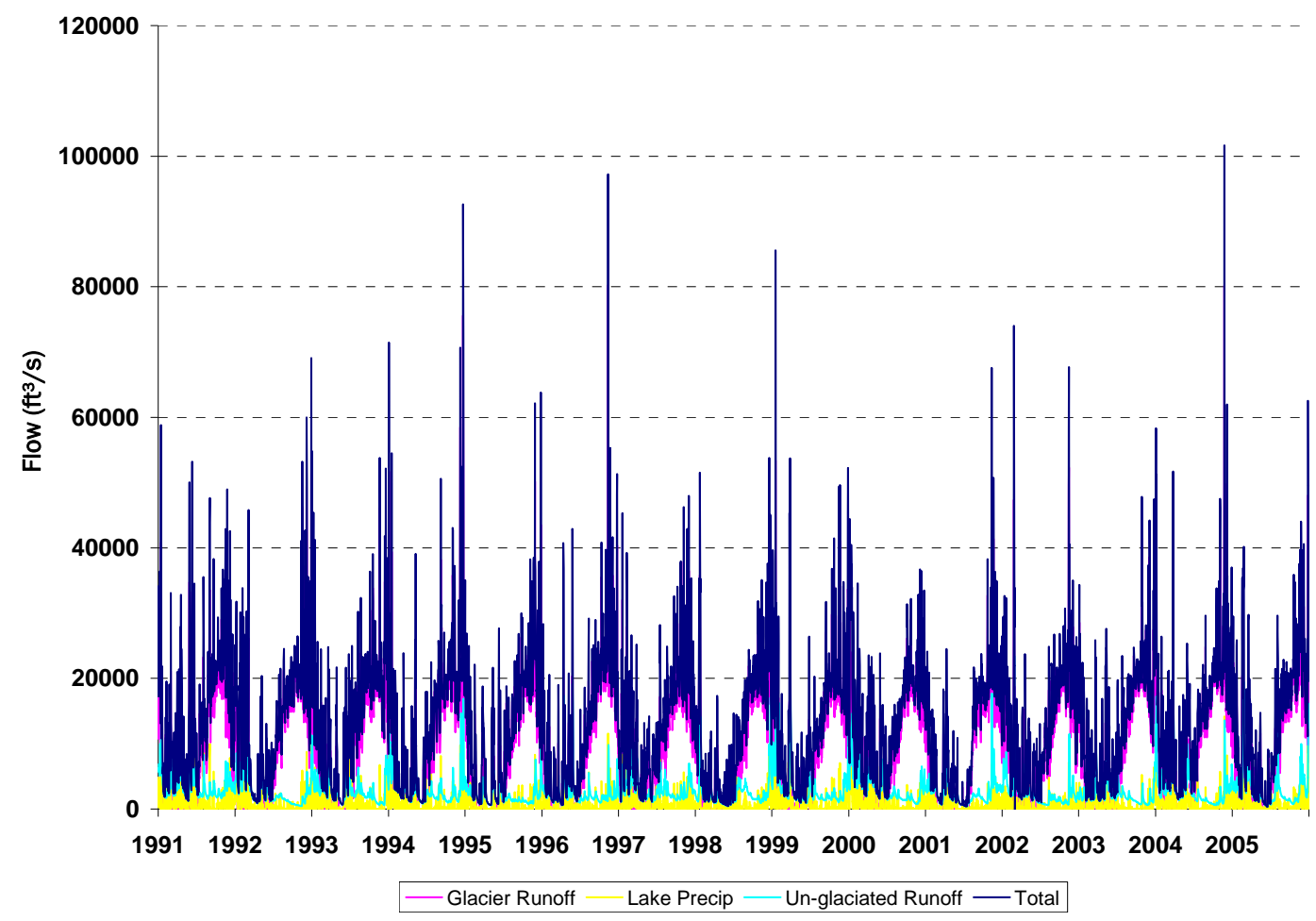

Figure 13. Estimated inflows into Russell Lake over the period of record.

To provide a check on the inflow values estimated by the hydrological model, we also estimated the inflow into Russell Lake using the regression equations developed for ungaged basins in Alaska by the USGS (Curran et al. 2003). These regression equations allow the magnitude of flows with annual return periods of 2 to 500 years to be estimated based on watershed parameters. The parameters required by the regression equation are watershed area (A), area of lakes and ponds in percent (ST), average annual precipitation $(\mathrm{P})$, and average J anuary temperature $(\mathrm{J})$. The values of these parameters for the Russell Lake watershed are listed in Table 3. The area of the Russell Lake watershed used did not include the area of Russell Lake itself. The area of lakes and ponds for the Russell Lake watershed outside of Russell Lake was estimated to be zero. The average annual precipitation and average J anuary temperature were both estimated based on the weather data recorded at the Yakutat Airport. Given the proximity of the Yakutat Airport, no attempt was made to adjust these values to more closely reflect the conditions of the Russell Lake watershed itself. 
Table 3. Parameters used in USGS regression equations.

\begin{tabular}{|c|l|c|c|}
\hline Parameter & \multicolumn{1}{|c|}{ Description } & Value & Units \\
\hline$A$ & Watershed area & 652 & mile $^{2}$ \\
\hline$S T$ & Area of lakes and ponds & 0 & $\%$ \\
\hline$P$ & Mean annual precipitation & 135.5 & inches \\
\hline$J$ & $\begin{array}{l}\text { Mean minimum January tempera- } \\
\text { ture }\end{array}$ & 23.51 & ${ }^{\circ} \mathrm{F}$ \\
\hline
\end{tabular}

The series of maximum annual inflow determined by the hydrological model of the Russell Lake watershed was also analyzed to estimate the magnitude of inflows with similar return periods using the U.S. Army Corps of Engineers Statistical Software Package (HEC-SSP) (U.S. Army Corps of Engineers 2008). These results are displayed in Figure 14. There is reasonable agreement between the USGS regression results and the statistical results based on the hydrological model.

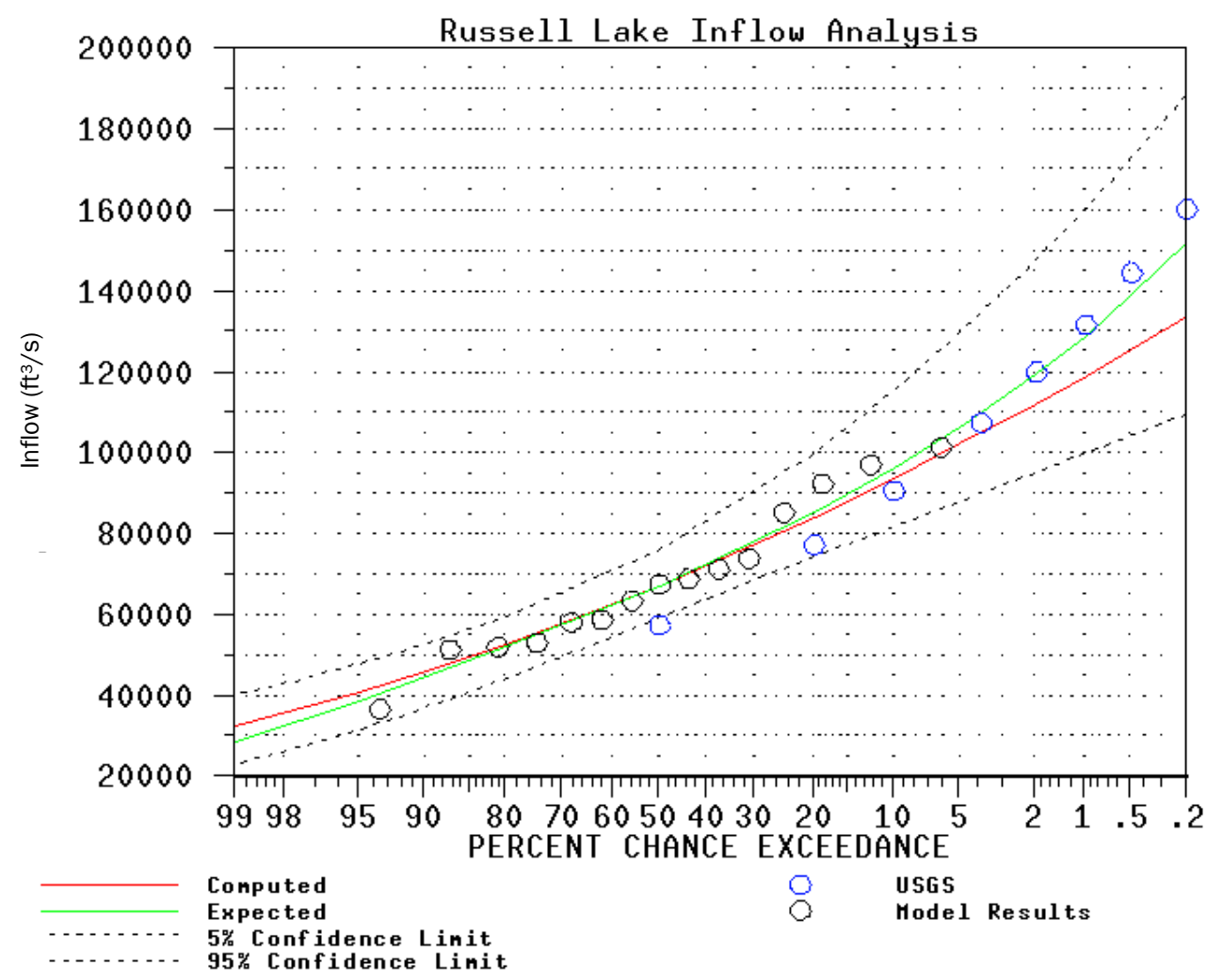

Figure 14. Annual maximum flows in Russell Lake based on USGS regression equations and the hydrological model developed for this study. 


\section{Situk River System Flow Simulation}

The Situk River as it currently exists can be divided into two reaches: the Upper Situk River and the Lower Situk River. The division between these two reaches is where the Old Situk channel enters the Situk. The source of the Upper Situk River is Lake Situk (visible in Fig. 1). The current channel conditions of the Old Situk differ significantly from the Upper and Lower Situk rivers because there is no significant flow in the upper portion of the Old Situk. This upper portion of the Old Situk extends from the Notch area to downstream of a small pond. The channel of the upper portion of the Old Situk is currently heavily forested, with extensive tree growth in the channel. If Russell Fiord were to be closed off by Hubbard Glacier, Russell Fiord would become Russell Lake. Russell Lake would have no outlet until the water level of Russell Lake reached an elevation of approximately 137.2 $\mathrm{ft}$ MLLW. The flow in the Old Situk would then increase dramatically as water spilled out of Russell Lake through the Notch area. The Situk River system would then consist of three reaches: the Lower Situk, the Upper Situk, and the Old Situk. All three of these reaches are included in the current modeling effort.

\section{River channel geometry}

The channel geometry describes in detail the shape and roughness of the flow channels and any culverts, bridges, or other structures. Describing the shape of the channel requires the development of cross sections that are perpendicular to the expected flow velocity; the number and location of the cross sections are determined by the expected flow conditions. The roughness of the channel determines the flow resistance of the channel.

The flow resistance of the Situk River system is complex because of the varied channel conditions. In the upper portion of the Old Situk, the current channel is heavily forested with extensive tree growth, whereas the Upper and Lower Situk have existing channels. Flow out of Russell Lake is expected to greatly increase the discharge in the Old Situk and Lower Situk, leading to extensive out-of-channel flows. These out-of-channel flows would occur largely through the forested floodplains. The description of the river channel geometry was based on a Digital Elevation Model (DEM) created from LiDAR data as described in the next sections. A variety of 
software tools and additional information sources were then used to create the HEC-RAS geometry data.

\section{LiDAR data acquisition}

In late August and September 2005, NASA's Airborne Topographic Mapper (ATM) LiDAR instrument was used to survey the Hubbard Glacier terminus, its source area, and the Yakutat forelands. NASA's ATM LiDAR is an airborne-based scanning laser altimeter operated from NASA's P3b or a twin-engine light aircraft based out of NASA's Wallops Flight Facility, Wallops Island, VA. The ATM-IV sensor is a full-waveform LiDAR (Fig. 15) that operates at 10,000 pulses per second at a frequency-doubled wavelength of $532 \mathrm{~nm}$ in the blue-green spectral region. For each laser pulse emitted, a series of returned spatial vectors from the platform to the point of reflection is established, providing an extremely precise XYZ coordinate of the laser footprint throughout the echo waveform. Using a conical scanning mirror rotated at 10 (or 20) $\mathrm{Hz}$ at an off-nadir angle of $10^{\circ}$, the beam of the ATM is directed along an elliptical scanning pattern beneath the aircraft. Swath widths directly correspond to flight altitude and rotation rates of the scanning mirror and are normally on the order of $2100 \mathrm{ft}(650 \mathrm{~m})$.

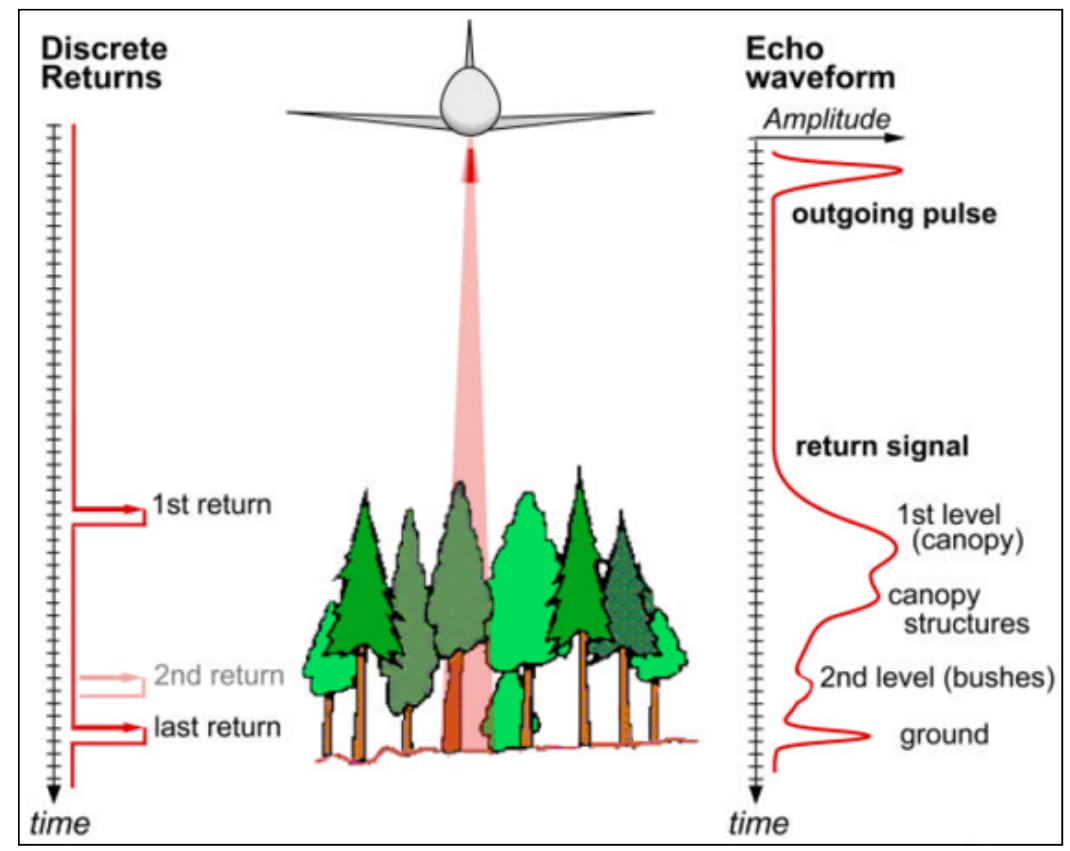

Figure 15. Discrete return LiDAR sensor and a full-waveform LiDAR system. The latter is similar to the ATM-IV used in 2005 to collect LiDAR data over the Yakutat forelands. 
The Yakutat was surveyed by a Twin Otter International twin-engine light aircraft equipped with the ATM-IV instrument, a laser Ring-Gyro Inertial Navigation Unit (INU), and two survey-grade GPS receivers, flown at an altitude of approximately $3300 \mathrm{ft}$. Two GPS receivers were used to record the aircraft's position throughout the survey flight. The aircraft GPS data were later combined with signals concurrently collected at a nearby GPS base station. Differential kinematic GPS techniques allow the position of the aircraft to be determined to within 2 in. $(5 \mathrm{~cm})$ (Krabill et al. 2000, 2004). The INU is used to provide the aircraft pitch, roll, and heading, which are then embedded in the ATM telemetry. By integrating individual measurements from the laser altimeter and kinematic GPS receivers, the ATM measures the surface topography to within approximately 2 in. GPS data were also collected at local benchmarks for comparison during postprocessing to validate the results.

\section{Point/DEM processing}

Data were collected and post-processed as a series of flightlines; each strip was imported into a project using TerraScan (Terrasolid, Ltd.). Creating a project combines the various flightlines into a DEM while breaking the dataset as a whole into manageable pieces.

Post-processing and data reduction included the following steps:

- The geographical coordinates (latitude, longitude, and height) were converted to cartographic coordinates (XYZ).

- The reference system was converted from ITRF94 to NAD83.

- The resulting cartographic coordinates were converted to geographical coordinates referenced to NAD83 datum. This horizontal datum was converted using geo_nad83_cart from the National Geodetic Survey (NGS).

- The data referenced to NAD83 were then referenced to NAVD88 using the GEOID99 model. This vertical conversion was done using CRS_GEOID from NGS.

- All data were converted from geographic coordinates to UTM zone 7N.

Individual lines were then checked against adjacent lines to ensure a cohesive dataset. The data from each line were then combined and a classification routine was run to determine the initial surface model. 


\section{Correcting for MLLW datum}

In general, National Geodetic Survey (NGS) datasheets show agreement between orthometric heights from GPS (using their geoid models) and their own NAVD88 heights. However, the disagreement on NGS datasheets for Yakutat is around $1.5 \mathrm{~m}$. This is because the geoid or the modeled NAVD88 surface simply isn't well known in the vicinity of Yakutat, primarily because of isostatic rebound and tectonic uplift in the vicinity. For this reason, heights are listed as "local tidal" heights at Yakutat and not "NAVD88" as in most locations. NOAA adopted a procedure for computing accepted tidal datum for the National Water Level Observation Network (NWLON) using the last several years of sea level data versus the 19-year tidal epoch.

The conversion factor of $+5.279 \mathrm{ft}(+1.609 \mathrm{~m})$ to convert from MSL to MLLW in this study was based on the data shown in Table 4.

Table 4. NOAA tidal gage at Yakutat, Alaska.

\begin{tabular}{|c|c|}
\hline Station ID: 9453220 & Publication date: 09/12/2007 \\
\hline \multicolumn{2}{|c|}{ Name: Yakutat, Yakutat Bay, Alaska } \\
\hline NOAA Chart: 16761 & Latitude: $59^{\circ} 32.9^{\prime} \mathrm{N}$ \\
\hline USGS Quad: Yakutat C-5 & Longitude: $139^{\circ} 44.1^{\prime} \mathrm{W}$ \\
\hline \multicolumn{2}{|c|}{ Tidal datum at Yakutat, Yakutat Bay based on: } \\
\hline Length of series: & 5 years \\
\hline Time period: & January 2002-December 2006 \\
\hline Tidal epoch: & 1983-2001 \\
\hline \multicolumn{2}{|c|}{ Tidal datum referred to mean lower low water, in feet (meters): } \\
\hline Mean sea level (MSL) & 5.279 (1.609) \\
\hline Mean lower low water (MLLW) & $0.000(0.000)$ \\
\hline
\end{tabular}

\section{Final DEM processing}

The initial surface model was then produced using TerraScan's proprietary methods to create the final bare-earth dataset (Fig. 16). A 9.843-ft (3-m) DEM was generated from the final surface point data using Applied Imagery's QT Modeler. The DEM was then exported to an ESRI GRID format suitable for cross section generation within HEC-GeoRAS. The final Li- 
DAR dataset is referenced to UTM zone 7N NAVD88 (referenced to MLLW).

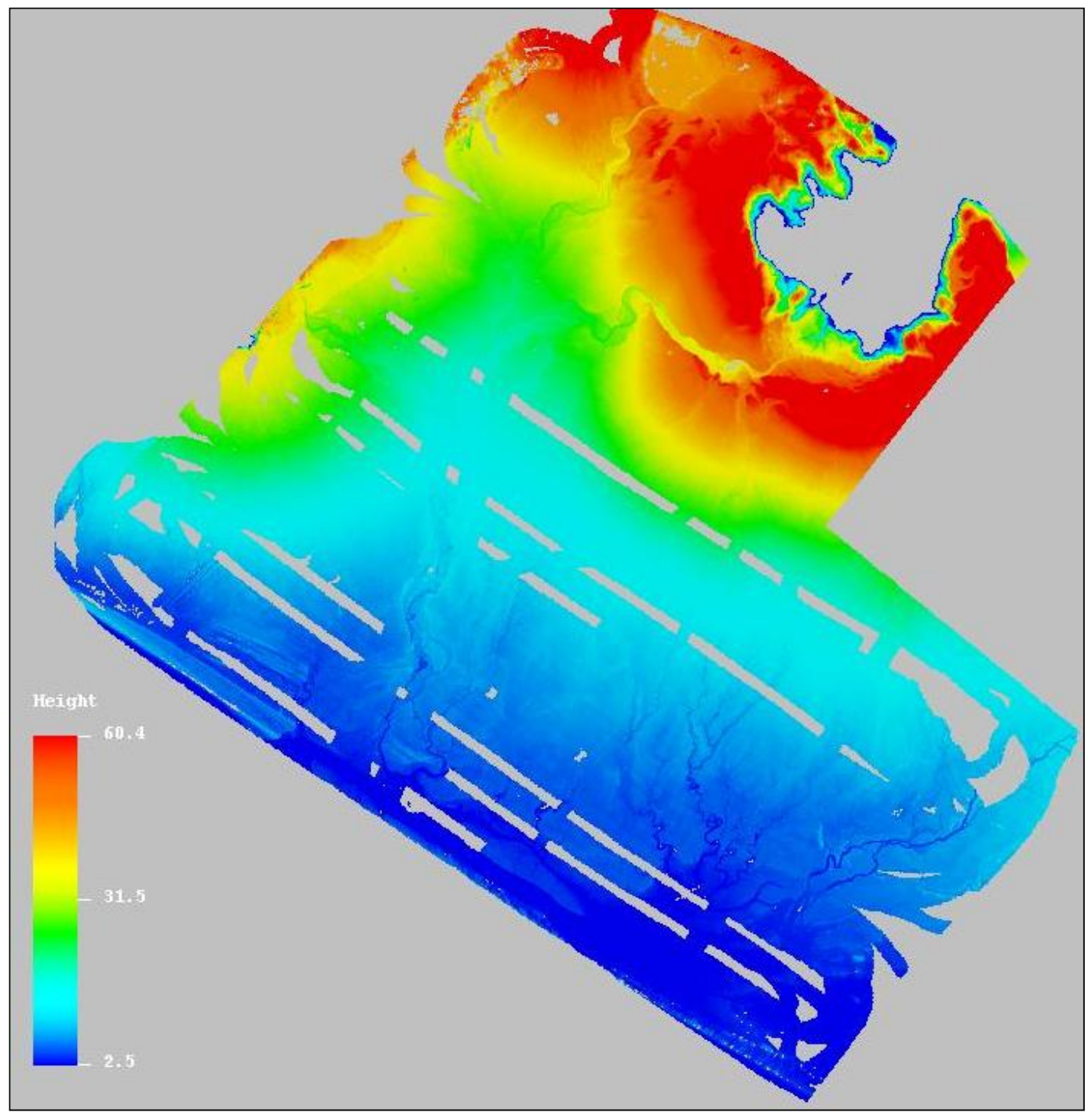

Figure 16. Color-shaded 9.843-ft (3-m) DEM of the Yakutat Forelands NASA ATM-IV LiDAR data. The strips of missing data were caused by equipment failure related to inclement weather and GPS signal degradation during acquisition flights.

\section{Estimating the channel flow resistance}

Flow resistance is generally characterized by the Manning's roughness coefficient, and guidance is available from several sources (see, e.g., Chow 1959; Barnes 1967; Arcement and Schneider 1984; U.S. Army Corps of Engineers 2002). Typical values of the Manning's roughness coefficient are listed in Table 5 (U.S. Army Corps of Engineers 2002). The resistance can also be estimated based on hydraulic theory and laboratory and field measurements (see, e.g,, Musleh and Cruise 2006; Stone and Shen 2002). The 
choice of the Manning's roughness coefficient will depend on the type and density of the vegetation in the channel and flood plain. Examples of the type and density of the vegetation in the upper portion of the Old Situk are shown in Figure 17.

Table 5. Manning's $n$ values from Table 3.1 in the HEC-RAS Reference Manual (U.S. Army Corps of Engineers 2002).

\begin{tabular}{|l|l|c|c|c|}
\hline & & Minimum & Normal & Maximum \\
\hline High grass & & 0.030 & 0.035 & 0.050 \\
\hline Scattered brush & Heavy weeds & 0.035 & 0.050 & 0.070 \\
\hline Cleared land with tree stumps & No sprouts & 0.030 & 0.040 & 0.050 \\
\cline { 2 - 5 } & Heavy sprouts & 0.050 & 0.060 & 0.080 \\
\hline \multirow{2}{*}{$\begin{array}{l}\text { Heavy stand of timber, few down } \\
\text { trees, little undergrowth, }\end{array}$} & No flow in branches & 0.080 & 0.100 & 0.120 \\
\cline { 2 - 5 } & Flow in branches & 0.100 & 0.120 & 0.160 \\
\hline Dense willows, summer, straight & & 0.110 & 0.150 & 0.200 \\
\hline
\end{tabular}

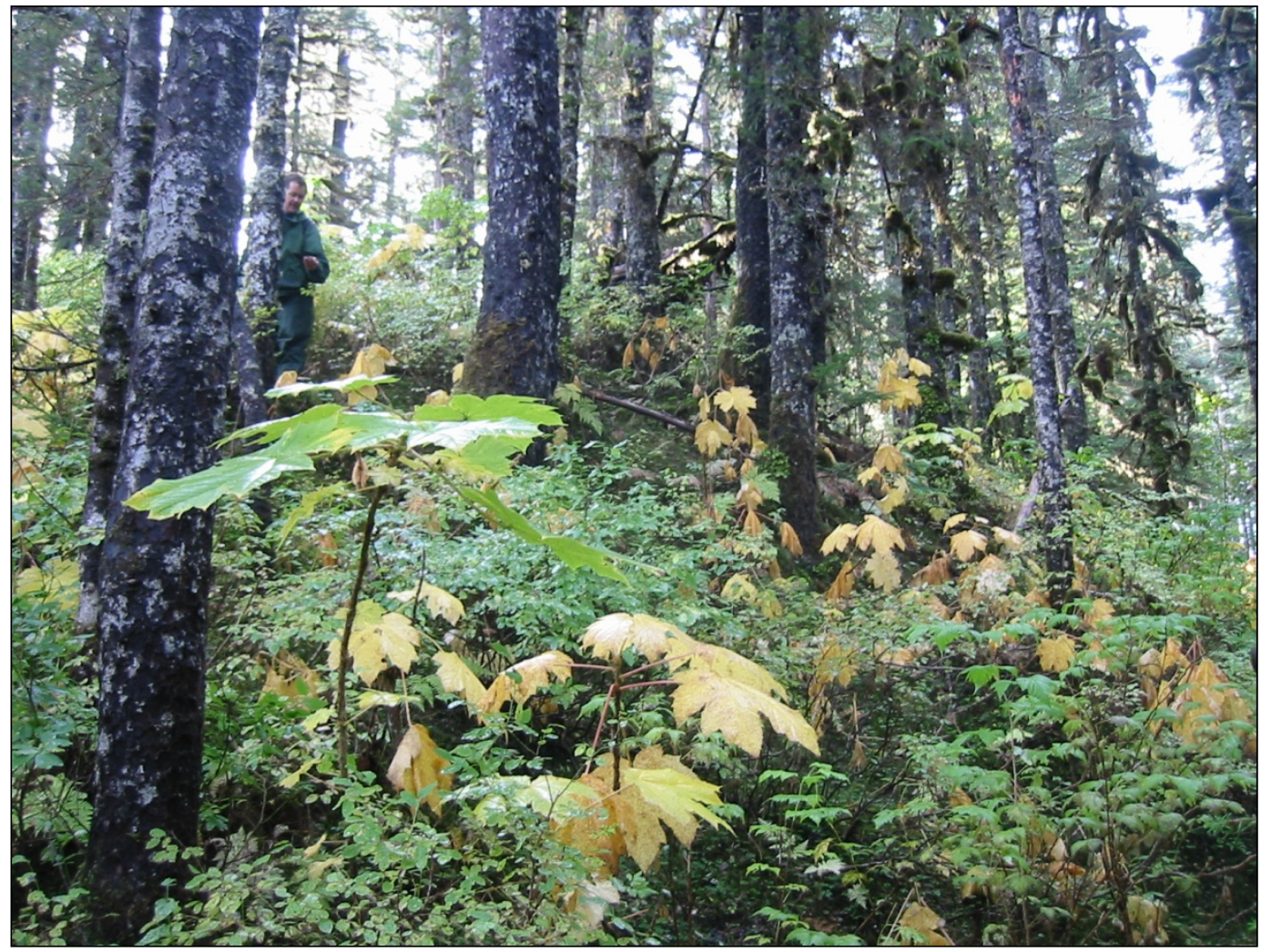

a. 


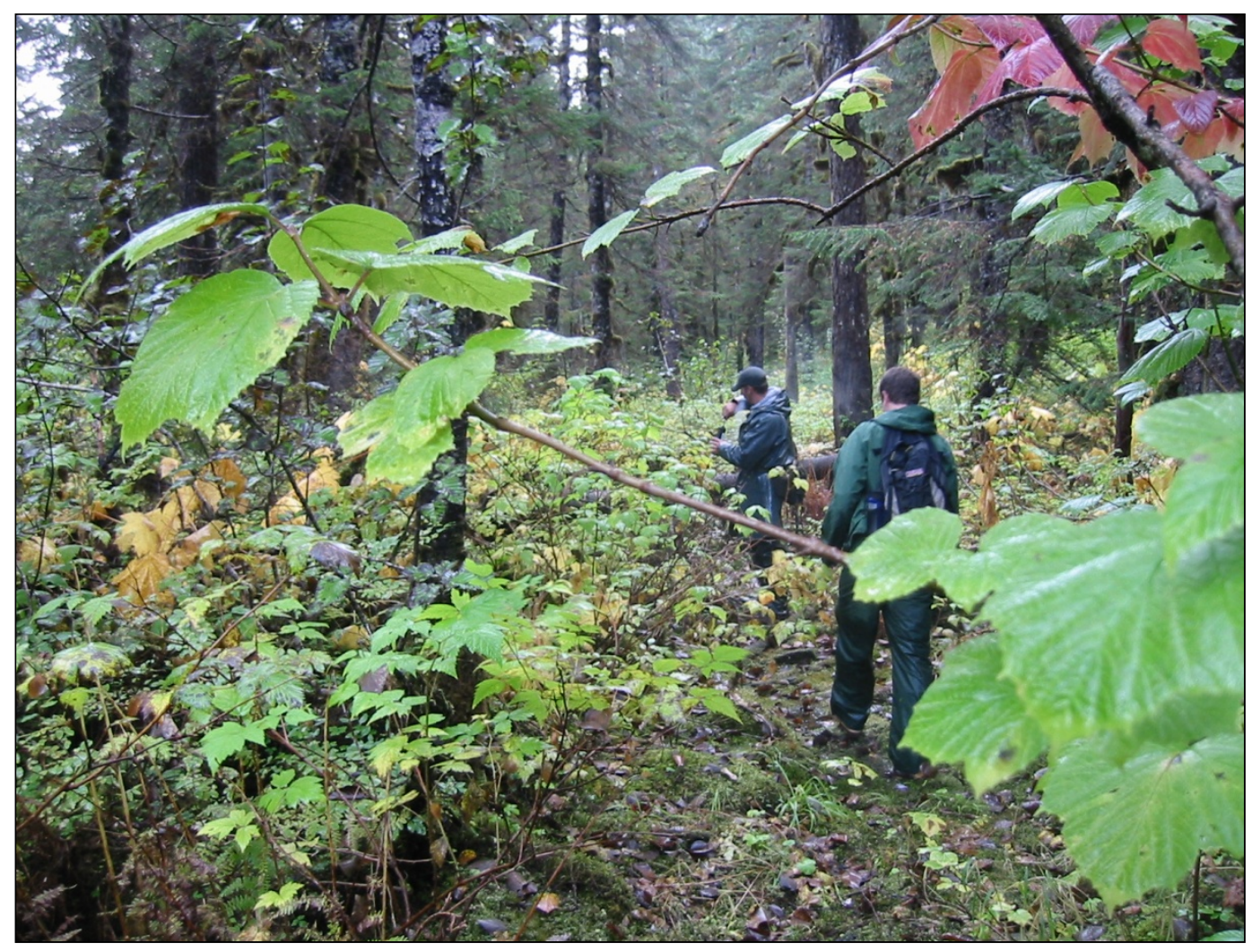

b.

Figure 17. Vegetation in the Notch area of Old Situk River.

A previous investigation of flow in the Situk River (Miles 2004) estimated Manning's roughness coefficient values of 0.04 for the channel (with some 0.05) and 0.08- 0.10 for the overbanks (with some areas as high as 0.012). Table 6 lists the values for Manning's roughness coefficient adopted for this study.

Table 6. Adopted Manning's $n$ values.

\begin{tabular}{|l|l|c|}
\hline Flow Area & \multicolumn{1}{|c|}{ Conditions } & Manning's $n$ \\
\hline \multirow{2}{*}{ Channel } & With Trees & 0.10 \\
\cline { 2 - 3 } & Cleared or existing & 0.04 \\
\hline \multirow{2}{*}{ Overbanks } & Forest & 0.10 \\
\cline { 2 - 3 } & Grassy fields & 0.035 \\
\hline
\end{tabular}




\section{Development of HEC-RAS geometry for Situk River}

Geometry data for the HEC-RAS model of the Situk River were developed using HEC-geoRAS (U.S. Army Corps of Engineers 2005), which runs as an extension in the ArcGIS environment. The geometry data were developed based on the 9.843-ft (3-m) DEM derived from the LiDAR data. Other spatial data used to develop the geometry data include USGS topographic maps (USGS 1:25000 scale Yakutat Series, 1959 (6 maps); USGS 1:63000 scale Yakutat Series, 1959 (23 maps); USGS Mt St. Elias Series 1985 (12 maps)) and a SPOT image of the forelands area (SPOT Image Group, www.spot.com). Contour lines of 1 and $5 \mathrm{~m}$ were developed from the DEM using the Spatial Analyst tool, which was useful in developing the cross section lines. The geometry data were developed in SI units to avoid converting the DEM to a datum based on U.S. customary units. The geometry data were converted into U.S. customary units in HEC-RAS. The known elevations of the Yakutat Airport runways were used to assess the accuracy of the DEM (Table 7).

Table 7. Comparison of elevations on Yakutat runways (feet MLLW).

\begin{tabular}{|l|c|c|c|}
\hline & CAD drawing & LiDAR & USGS topographic map \\
\hline SW end of runway & 18.4 & 17.2 & 18.4 \\
\hline Intersection of runways & 36.74 & 33.0 & \\
\hline SE end of runways & 25.94 & 25.8 & 25.0 \\
\hline
\end{tabular}

The gaps in the DEM coverage, as described above, presented a problem in the development of the HEC-RAS geometry. To generate a complete DEM of the Yakutat forelands, the elevations in the gaps in the LiDAR data were interpolated based on the elevations of nearby grid cells using the ArcGIS raster calculator. Unfortunately, many gaps were located directly over the Situk River (Fig. 18). These gaps were interpolated using elevation data from nearby grid cells located in the river overbanks. This often produced a stream channel geometry that was higher in elevation than actual. This issue was resolved by using the graphical cross section editor in HEC-RAS to manually deepen the channels. 


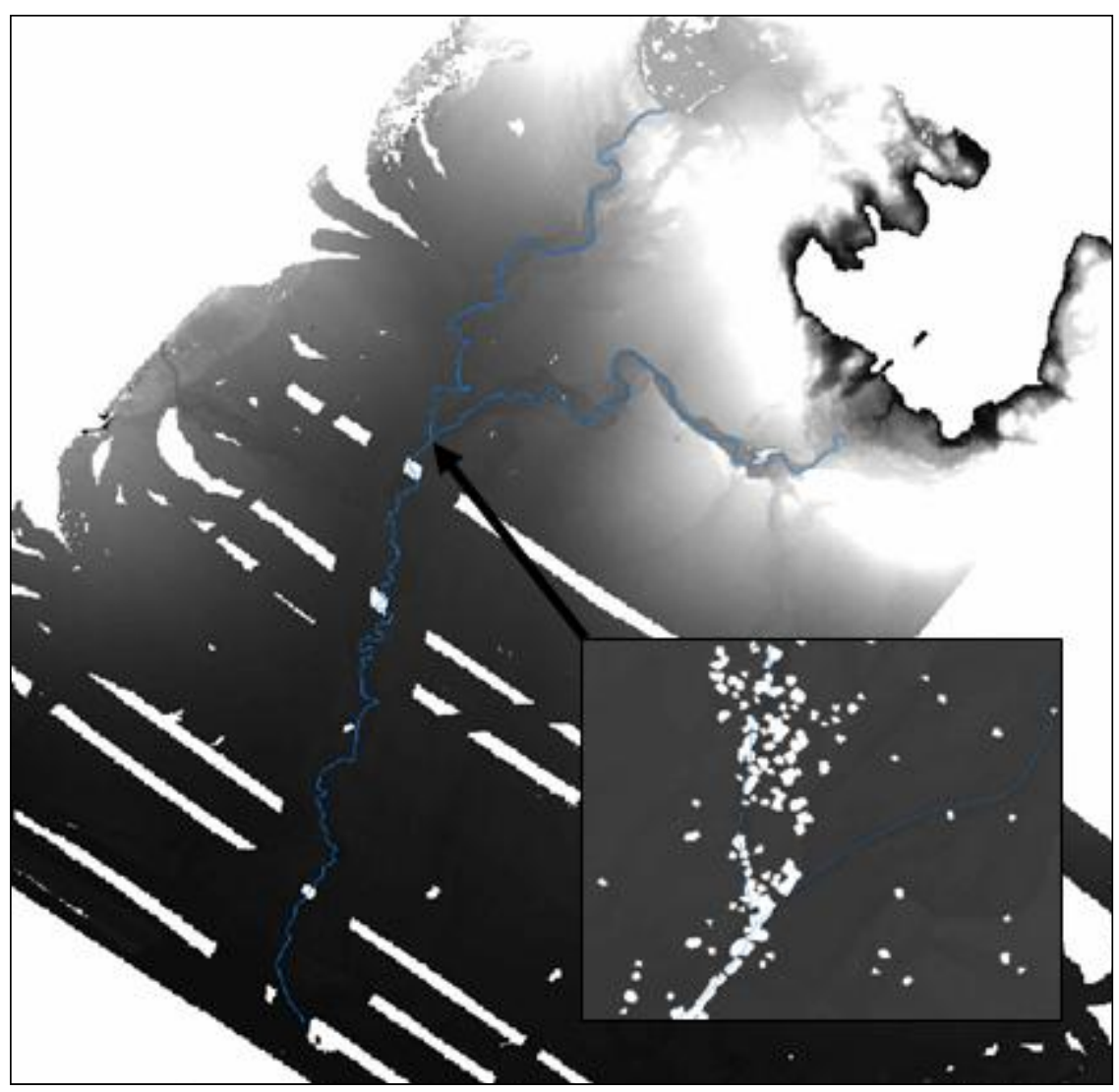

Figure 18. LiDAR data. Inset shows gaps over Situk River.

GeoRAS was used to develop geometry data for the HEC-RAS model, including the stream centerline, cross sections, bank stations, and Manning's $\mathrm{n}$ values. The stream centerline, bank lines, and flow paths were digitized using the SPOT image and the topographic maps. The Situk River was divided into two reaches: the Upper Situk and the Lower Situk. The Old Situk River was modeled as a tributary entering the Situk River at the upstream end of the Lower Situk River reach. Cross sections were placed at intervals along the streams, perpendicular to the contours. The flow paths were used to calculate the distance between cross sections. On the Old Situk River, the first cross section was placed upstream of the Notch area. On the Upper Situk River, the first cross section was placed at the outlet of Situk Lake, the source of the Upper Situk. At the downstream end of the Lower Situk River, cross sections were placed approximately $82 \mathrm{ft}(25 \mathrm{~m})$ off the shore into the Pacific Ocean to capture sea level as the downstream boundary condition. A polygon feature was developed for the various land conditions in the Yakutat forelands area as shown on the SPOT imagery, e.g., forested, grass, and channel. The polygon feature was used to assign 
Manning's $n$ values to parts of the cross sections for import into HEC-RAS (Fig. 19).

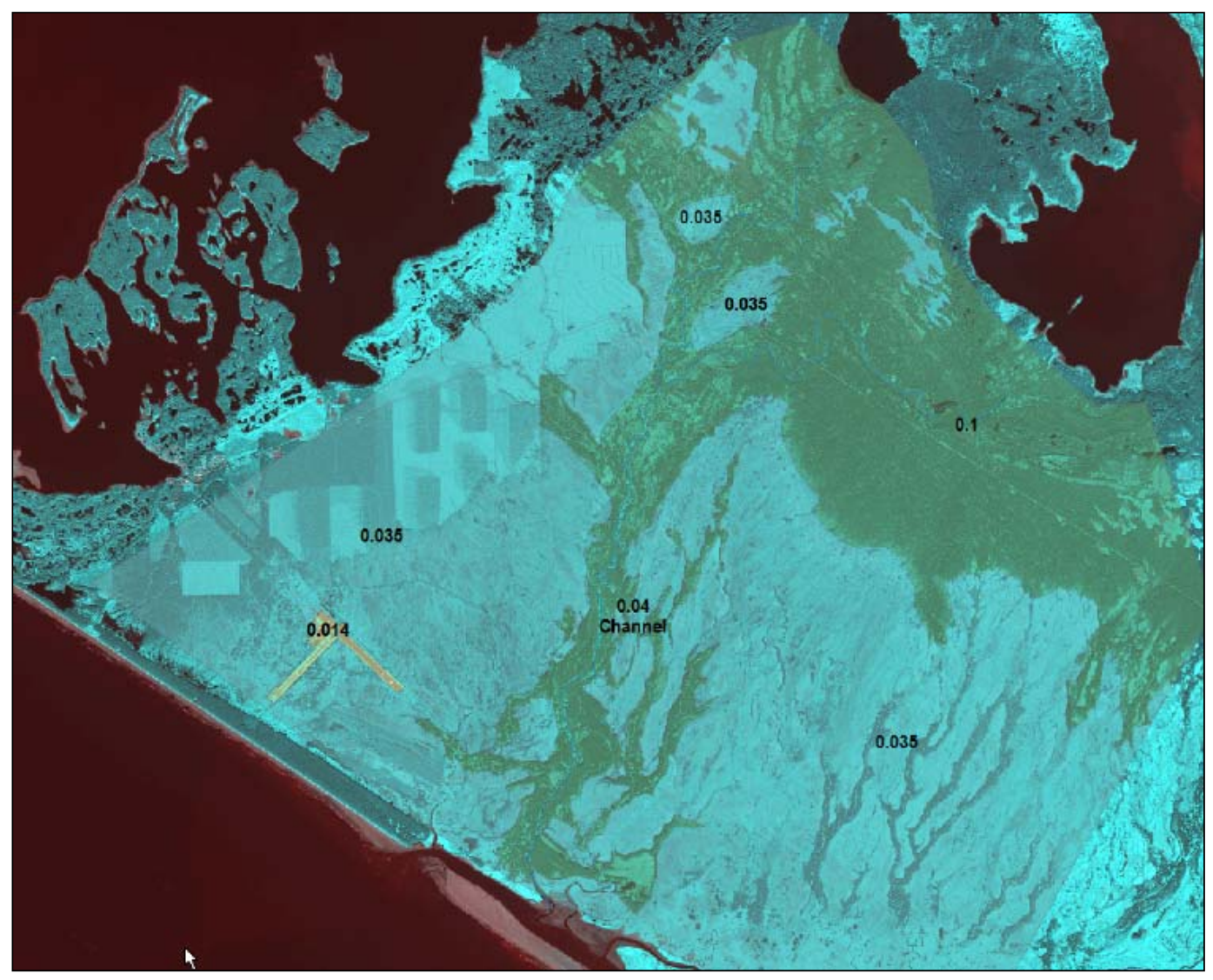

Figure 19. Manning's $n$ values for the Situk River model.

The completed Situk River geometry was imported from GeoRAS into the HEC-RAS model. During the import process, the units were converted from SI to U.S. customary units. A background image of the Yakutat forelands area was added to the geometry model. Figure 20 shows the layout of the cross sections of the geometry model in HEC-RAS.

The bank stations were adjusted to match the location of the banks defined in the cross section geometry. Where the LiDAR gaps coincided with the stream channel, it was difficult to determine the bank locations. In these locations the background image was used to determine the channel banks. The channel cross section depths in these locations were adjusted downward to convey the necessary flow. 


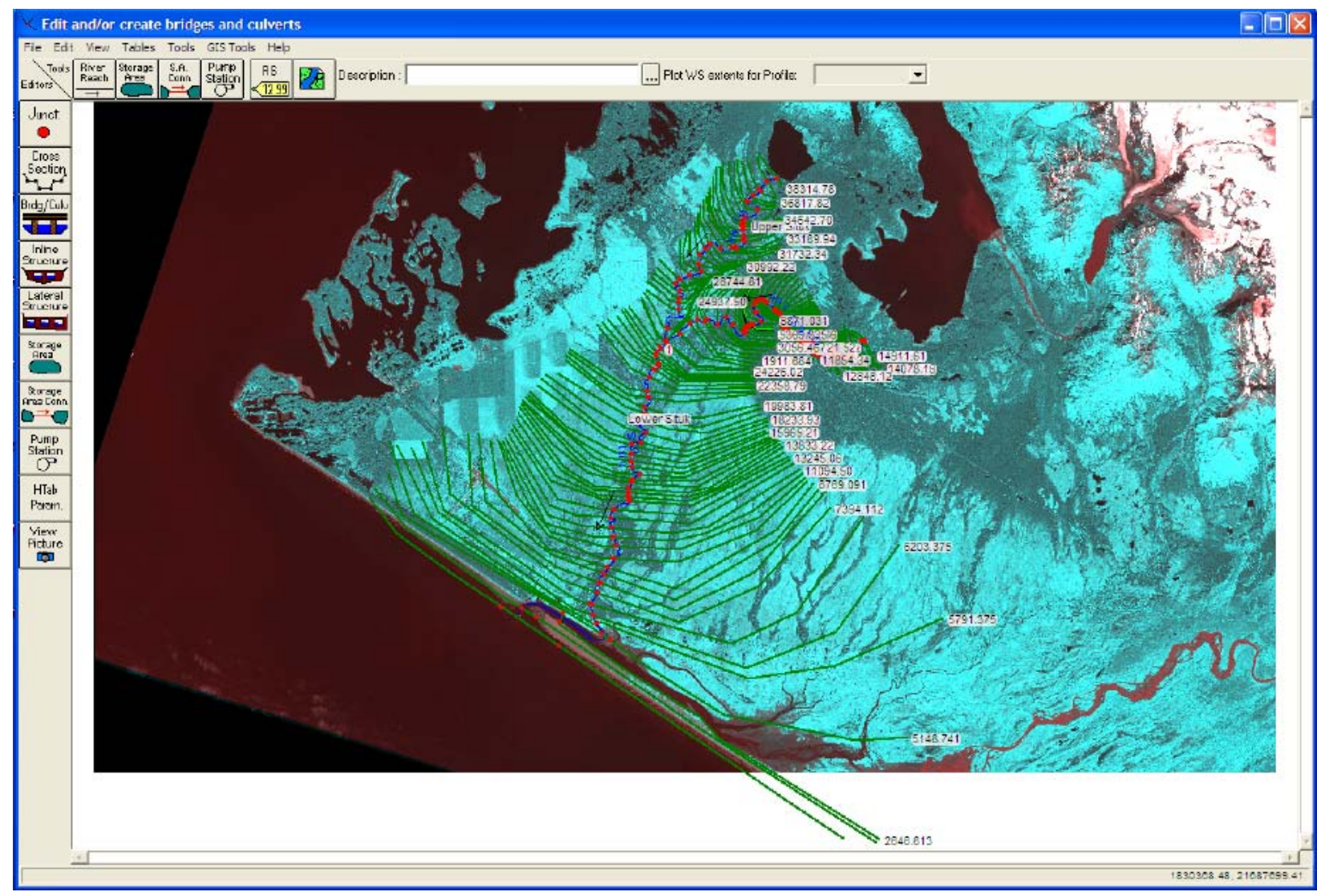

Figure 20. Situk River geometry model in HEC-RAS.

The LiDAR imagery also had significant gaps in the vicinity of the Yakutat airport. To fill in these gaps in the HEC-RAS model, CAD drawings of the airport ${ }^{1}$ and USGS topographic maps were used. Also, the LiDAR data had a large number of points along each cross section. Because HEC-RAS limits the number of point per cross section to 500, we used the filter tool in HEC-RAS to reduce the number of points in each cross section to 500. A comparison of the original cross sections to the filtered cross sections showed that the original geometry was not significantly altered.

The bridge located on the Old Situk River was added to the geometry at the location where the Forest Service roadway passes over the Old Situk River, based on the background image. The layout was based on a site visit, during which we noted five 6-ft culverts placed beneath the roadway at the stream invert. Figure 21 shows the Old Situk River bridge added to the HEC-RAS model.

\footnotetext{
1 "CAD Drawing of Yakutat Airport Property. State of Alaska Department of Transportation and Public Facilities, Southwest Region Planning. Prepared by Aeromap U.S. I.P.C." Undated. Provided by George Kalli, Alaska District, Corps of Engineers.
} 


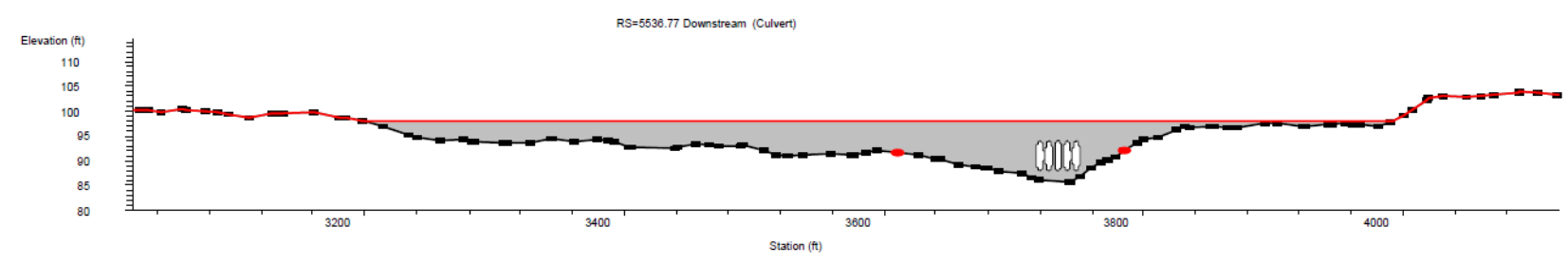

Figure 21. Old Situk River road crossing with culverts. In this figure the culverts appear as ovals because the vertical and horizontal scales differ.

The cross sections at the lower end of the Lower Situk River were modified to provide sufficient flow area to match the discharge measured on the days that the LiDAR data were recorded. Anomalously high points in the invert profile were removed as well.

Appendix A lists information on all the cross sections included in the HECRAS geometry. Cross sections were placed at representative locations that were close enough together to adequately describe changes in cross section geometry, overbank conditions, and slope. We developed 70 cross sections for the Old Situk, with an average spacing of $700 \mathrm{ft}$. This includes one section for the river crossing and one interpolated section. We developed 29 cross sections for the Upper Situk, with an average spacing of roughly $1500 \mathrm{ft}$. Finally, we developed 43 cross sections for the Lower Situk, with a spacing of roughly $1900 \mathrm{ft}$.

We developed two geometries of the Situk River. The first represented the Situk River system as it is now, with trees growing in the channel of the Old Situk River. For this geometry the Manning's n value of the channel in the upper reach of the Old Situk was set to 0.10, the equivalent of flow through trees. A second geometry file was created that represented the $\mathrm{Si}$ tuk River system after the trees had been eroded away. For this geometry the Manning's $n$ value of the channel in the upper reach of the Old Situk was set to 0.04 , the Manning's n value used for channel flow.

At this point, a series of steady flow profiles were generated to assess the performance of the HEC-RAS model. The model was assessed by its ability to match the observed stages and discharges at USGS gage 15129500, labeled "Situk R Nr Yakutat Ak" and listed in Table 1. The discharge range was arbitrarily selected to cover the range of likely flows. The ability of the model to match the observed stages is shown in Figure 22. 


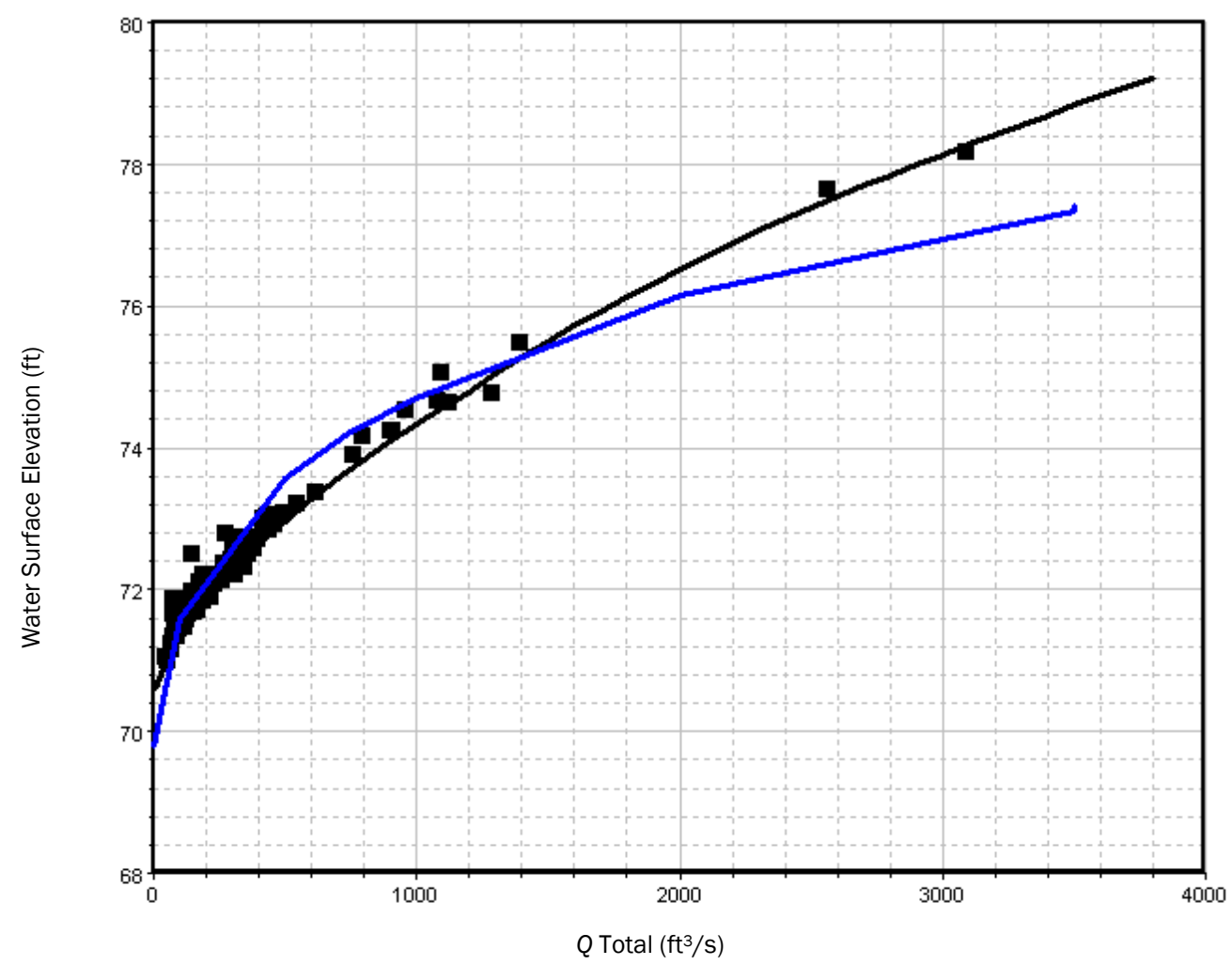

Figure 22. Rating curve (black) and observed stages at Situk River gage along with HEC-RAS results (blue) (datum: MLLW).

\section{Boundary conditions}

\section{Old Situk River inflows}

The closure of Russell Fiord would create Russell Lake. The watershed area contributing inflows into Russell Lake would be approximately 729 mile2. There would be no natural outlet of Russell Lake until it rose to approximately $137.2 \mathrm{ft}$ MLLW. At this level, the lake would begin to spill out through the Notch area and flow downstream through the Old Situk channel, into the Lower Situk Channel, and then into the Pacific Ocean. This portion of the study estimates the outflow from Russell Lake into the Old Situk River. There are two steps required to do this. The first is to estimate the runoff from the watershed contributing flow into Russell Lake. This step is described in the Russell Lake Hydrology section. The second step is to route this contribution from the surrounding watershed through Russell Lake and into the Old Situk River. This step is described next.

\section{Routing of Russell Lake inflows}

The inflow through Russell Lake was routed using the level-pool continuity equation 


$$
\frac{\mathrm{dS}(\mathrm{t})}{\mathrm{dt}}=\mathrm{I}(\mathrm{t})-\mathrm{Q}(\mathrm{t})
$$

where $\mathrm{S}(\mathrm{t})=$ volume of storage in the lake at time $\mathrm{t}$

$\mathrm{I}(\mathrm{t})=$ inflow into the lake at time $\mathrm{t}$

$\mathrm{Q}(\mathrm{t})=$ outflow out of the lake into the Situk River.

Let $E$ be the elevation of the lake water surface; then

$$
\mathrm{dS}(\mathrm{t})=\mathrm{A}(\mathrm{E}) \mathrm{dE}(\mathrm{t})
$$

where $\mathrm{A}(\mathrm{E})=$ surface area of the lake at elevation $\mathrm{E}$ $\mathrm{E}(\mathrm{t})=$ elevation at timet.

Then

$$
\frac{\mathrm{dE}(\mathrm{t})}{\mathrm{dt}}=\frac{\mathrm{I}(\mathrm{t})-\mathrm{Q}(\mathrm{E})}{\mathrm{A}(\mathrm{E})}
$$

Equation 10 was then solved using a third-order Runga-Kutta scheme (Chow et al. 1988) to arrive at a time series of the Russell Lake stages, E(t). Based on these results, the time series of the outflow from Russell Lake into the Old Situk River, Q(t), was then determined. The information needed to solve eq 10 includes the surface area-elevation curve for Russell Lake, $A(E)$, shown in Figure 23, and the outflow-elevation curve, Q(E), shown in Figure 24. Note that there are two outflow-elevation curves in Figure 24: one curve represents the outflow when trees are growing in the Old Situk River and the other when no trees are present. These curves were produced using HEC-RAS based on the following two geometries of the Situk River: the river system as it is now, with trees growing in the channel of the Old Situk River and the river system after the trees had been eroded away. 


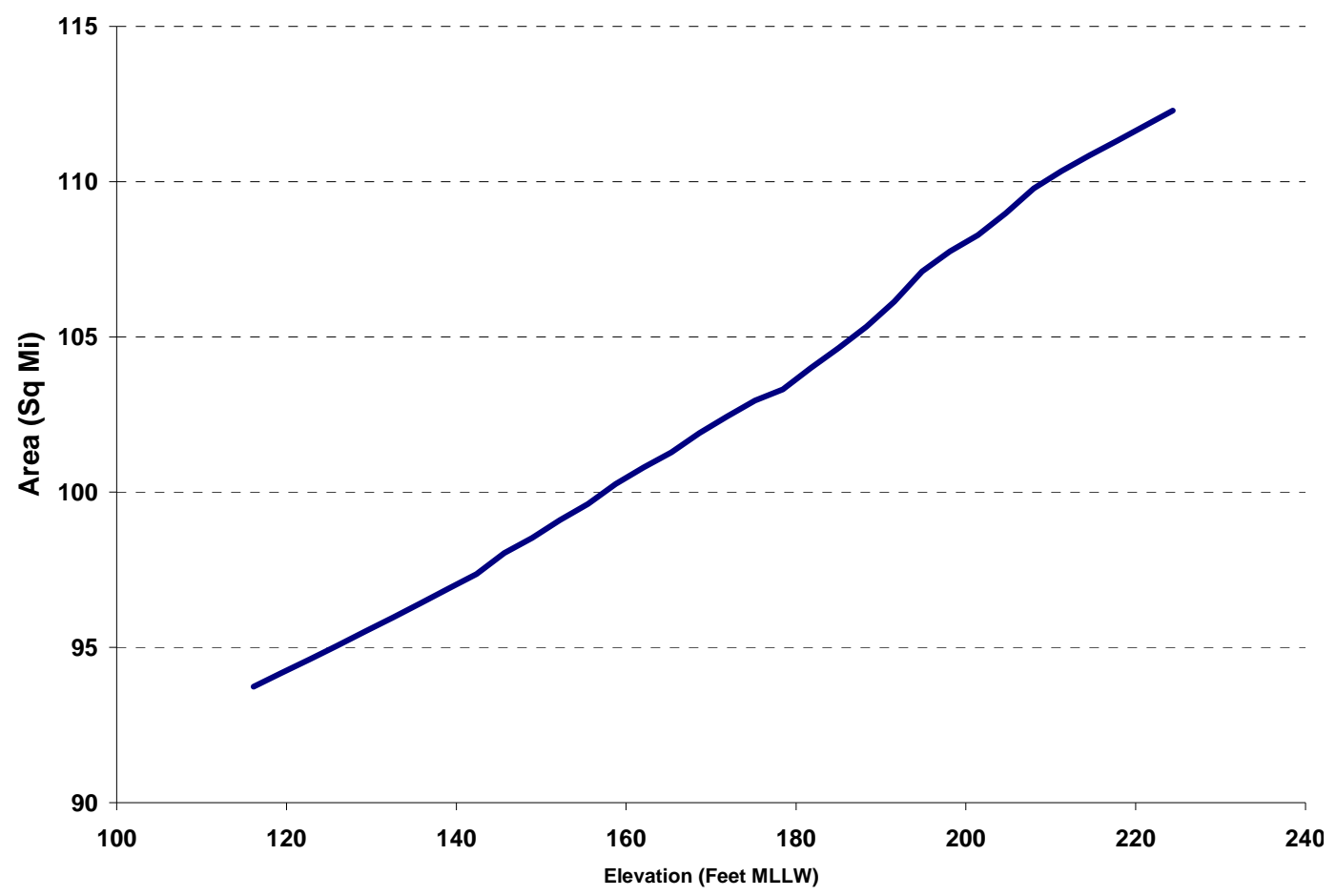

Figure 23. Surface area-elevation curve for Russell Lake.

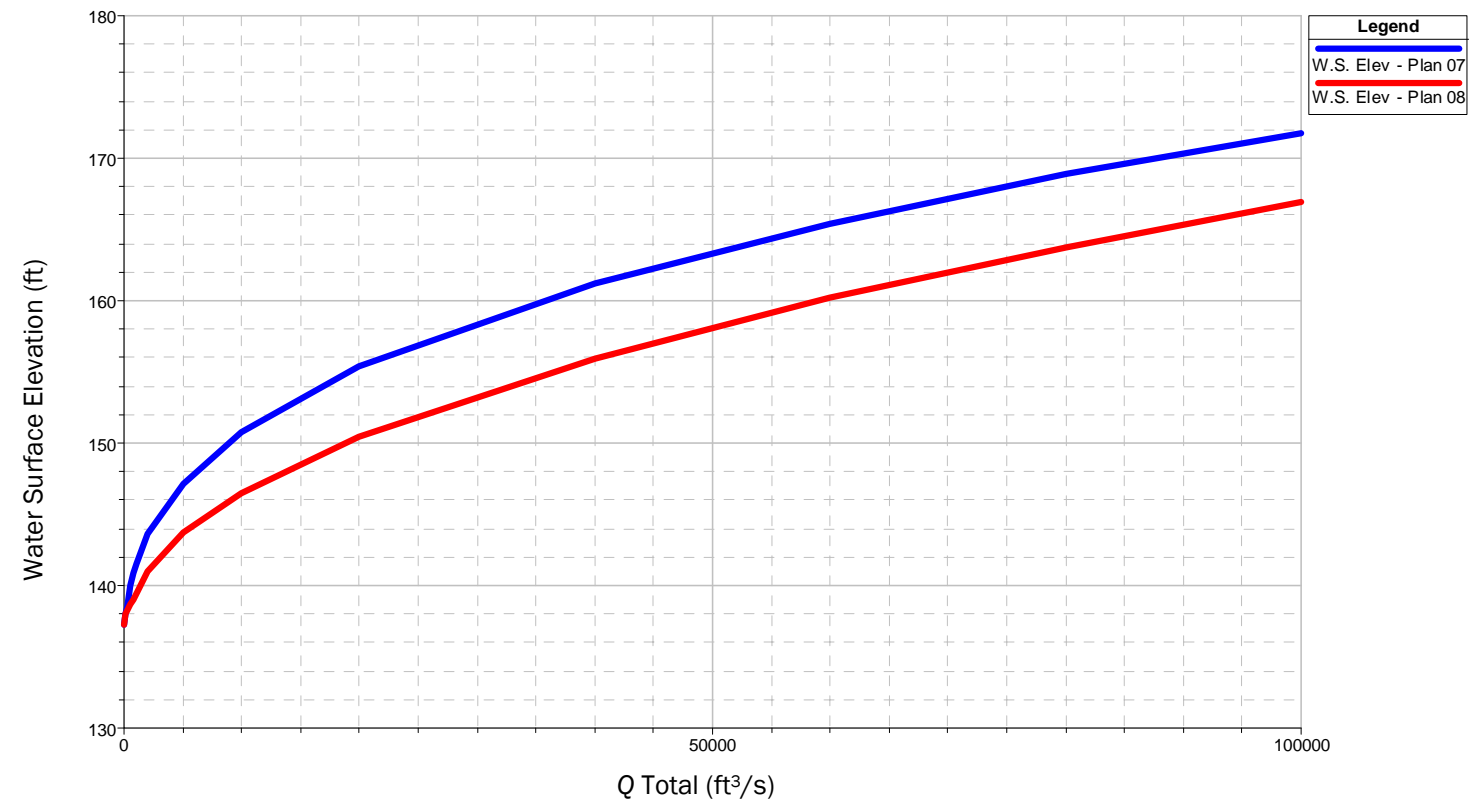

Figure 24. Outflow-elevation curve for Russell Lake for the channel with trees (blue) and without trees (red) (datum: MLLW). 


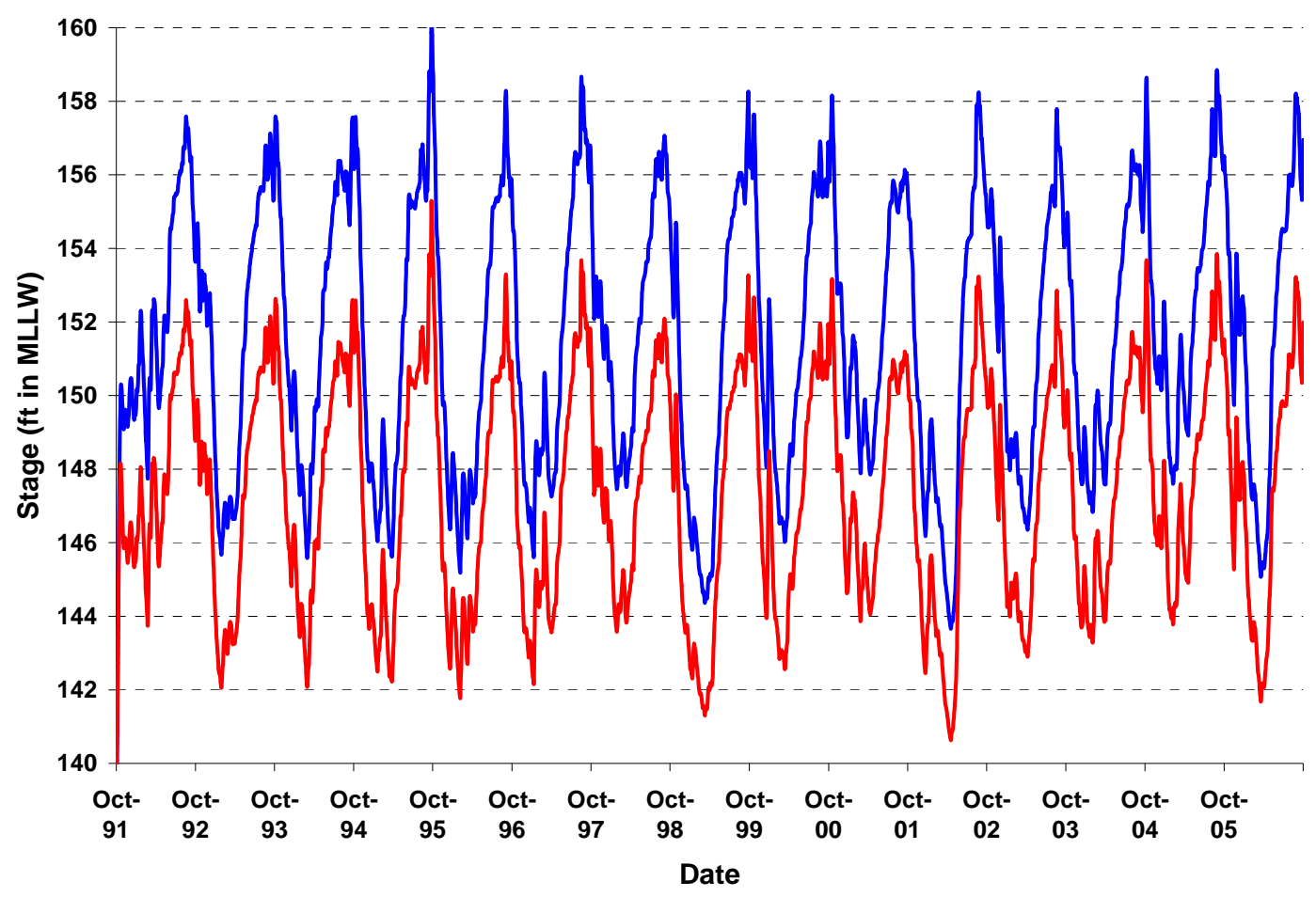

Figure 25. Estimated Russell Lake daily stages for the channel with trees (blue) and without trees (red) (Datum: MLLW).

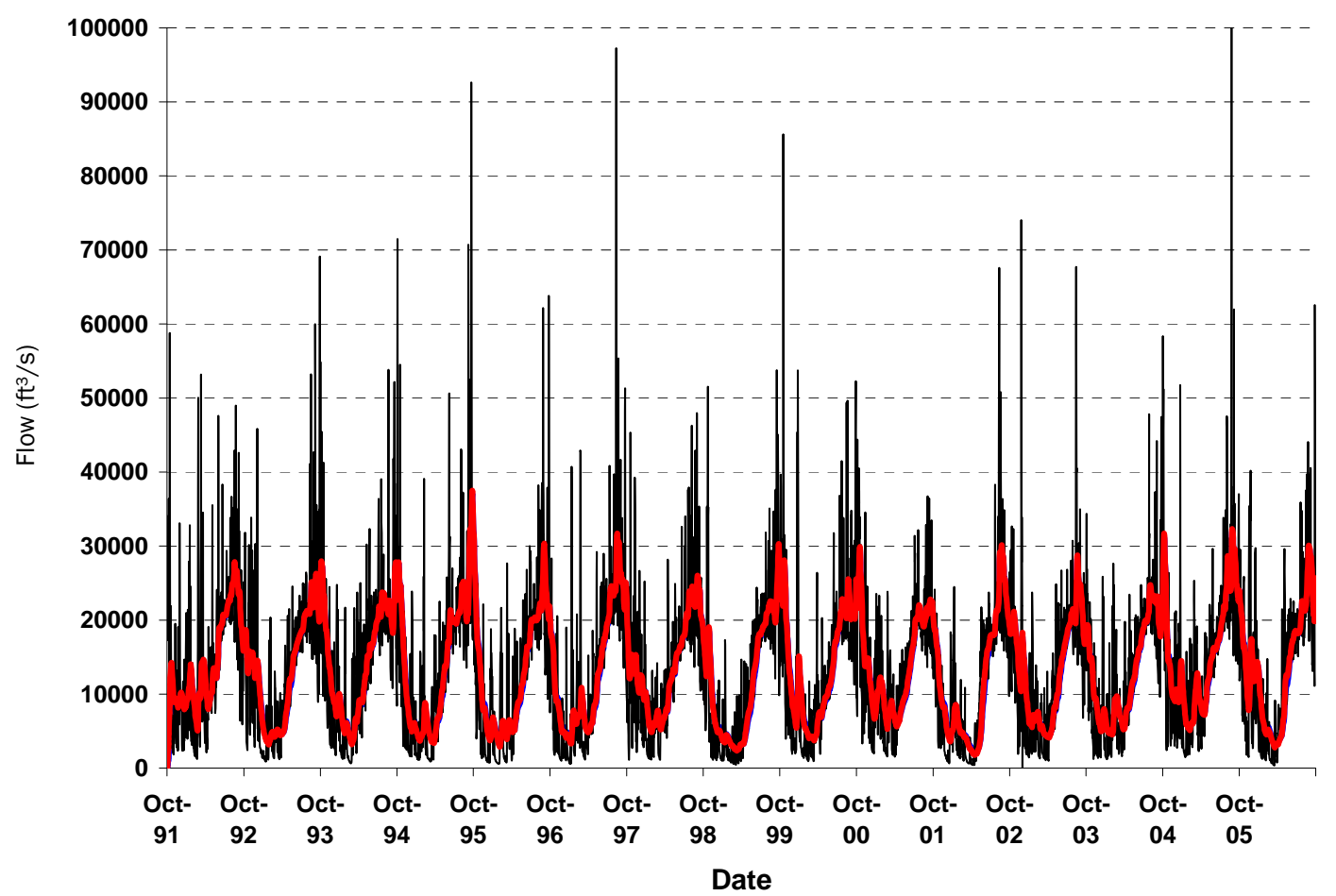

Figure 26. Simulated inflows (black) and outflows (red) of Russell Lake.

The resulting daily water surface elevations of Russell Lake, E(t), are shown in Figure 25 for both outflow conditions. The Russell Lake stages 
are significantly different for the two outflow conditions; the channel with trees produces considerably higher stages. Figure 26 shows the daily outflow from Russell Lake into the Situk River, Q(t), and the daily inflow into Russell Lake, I(t). The wide day-to-day variations in inflows are strongly attenuated by routing through Russell Lake.

The calculated outflows into the Old Situk River are shown in Figure 27. There is little difference between the outflows for the channel with and without trees, even though there is a significant difference in the lake levels between the two conditions. This suggests that the outflows from Russell Lake into the Old Situk River are largely determined by the inflows into the lake and not by the particular geometry and roughness of the outflow channel.

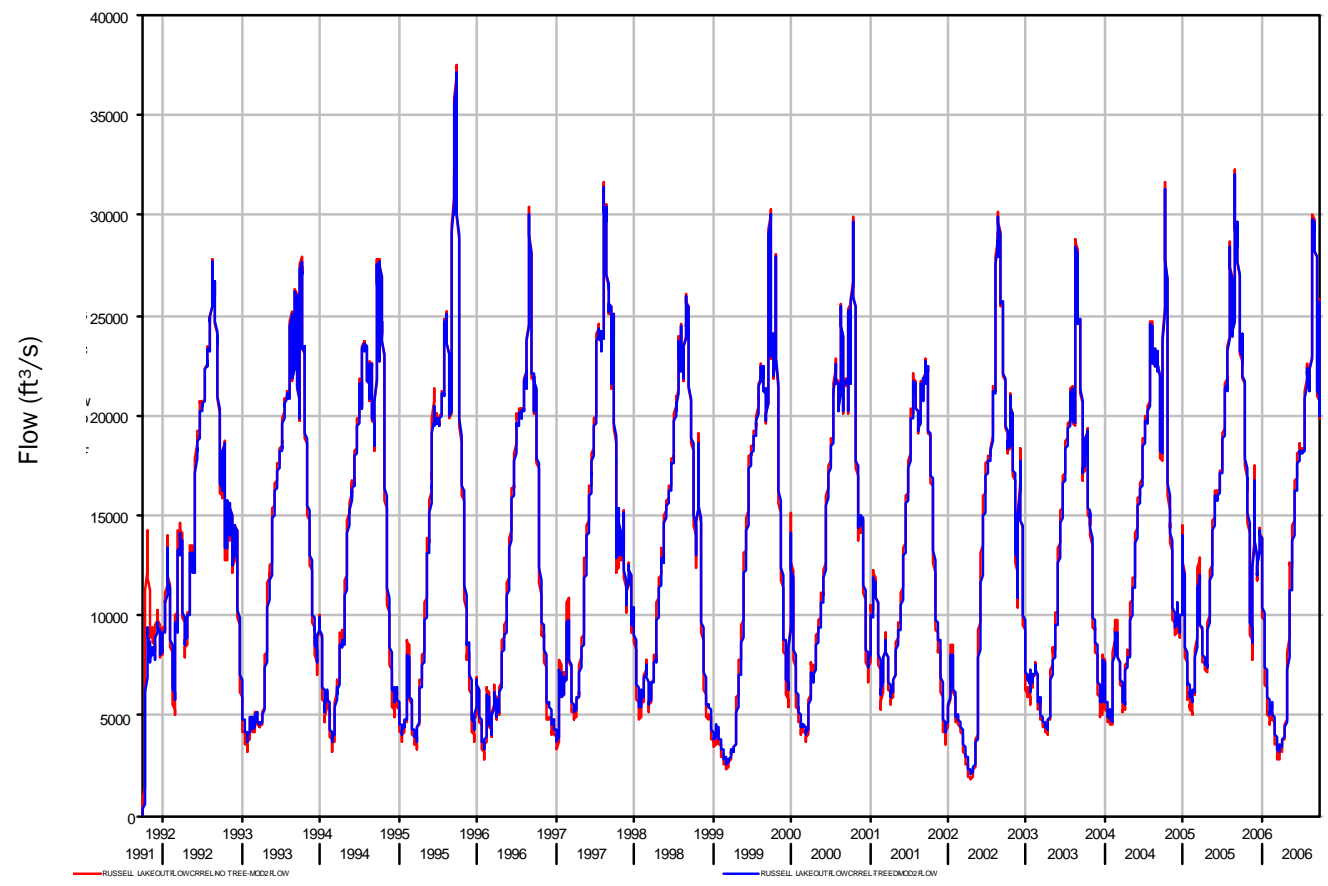

Figure 27. Simulated outflows of Russell Lake for the channel with trees (blue) and without trees (red). (The outflow curves are very similar.)

\section{Upper Situk River inflows}

The upstream boundary condition for the Upper Situk River flow was derived from the daily discharge recorded at USGS gage 15129500, labeled "Situk R Nr Yakutat Ak," and listed in Table 1. The outflow from Situk Lake provides the flow at the upstream end of the Old Situk River. At this point the drainage area of the Situk River is approximately 13.76 mile2, significantly smaller than the total drainage area at the gage of 36.0 mile22. 
The flows out of Situk Lake were estimated by reducing the daily average flow recorded at the gage by the ratio of the drainage areas, $13.76 / 36$, or 0.382. The difference between the flows out of Situk Lake and the daily average flow recorded at the gage was added as a lateral inflow at Section 28744.81.

\section{Pacific Ocean water levels}

The downstream water surface elevation is determined by the level of the Pacific Ocean. The NOAA tidal gage at Yakutat, Alaska (Table 4) provided hourly information on the water surface elevation (Fig. 28). The period of record for which electronic data were available was 1961 to the present. Yearly data files were downloaded from the NOAA web site

\section{(http:// www.tidesandcurrents.noaa.gov)}

and entered into a HEC-DSS database. The data, originally in hourly form, were then converted to daily averages. The daily average water surface elevation is shown in Figure 28. Note the distinct downward trend in the water surface elevation with time. This apparently results from the "extreme" uplift of southeast Alaska, which is thought to arise from isostatic rebound caused by glacial retreat following the Little Ice Age (Larsen et al. 2005).

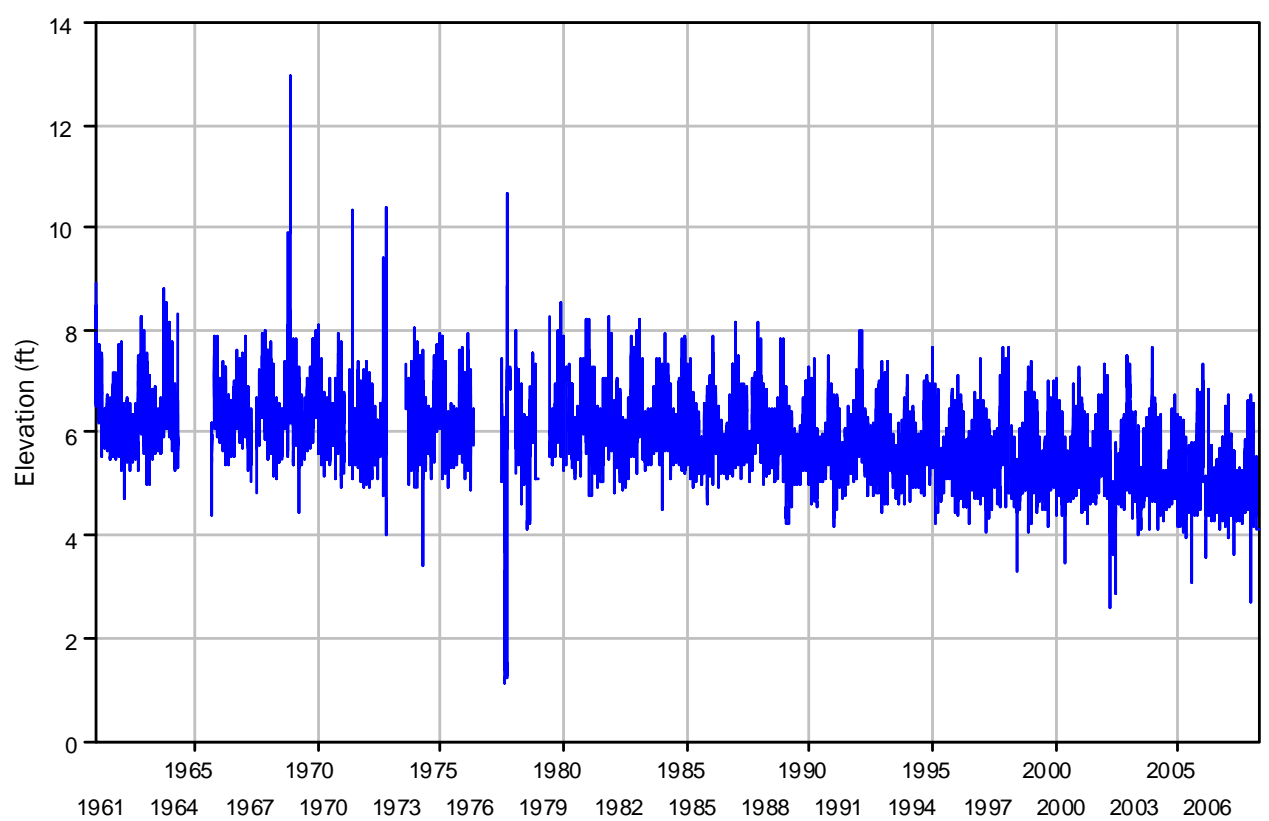

Figure 28. Daily average Pacific Ocean surface elevation at Yakutat, Alaska (MLLW). 


\section{Flow simulation}

\section{Period of record simulation}

At this point two simulations of the flows in the Situk River were performed covering the period from 1 November 1991 through 20 J anuary 2006. The simulation started on 1 November 1991, even though the inflows into Russell Lake were estimated starting on 1 October 1991. This first month was avoided because Russell Lake was filling during this time and the results were not representative of the long-term outflow. The simulation time step was 1 day, which is too long to capture any short-term flow dynamics on the Situk River system. However, the statistics of the flow conditions in the Situk River can be easily estimated based on the results of a long-term simulation. Estimating the statistics of the flow conditions without this type of simulation would be difficult because of the natural and large variability in the upstream inflows and the downstream Pacific Ocean elevation. Table 8 describes the data used in these flow simulations. The simulation results are discussed in the next section.

Table 8. Data used in the unsteady flow simulations for the Situk River.

\begin{tabular}{|c|c|c|}
\hline \multicolumn{3}{|r|}{ Simulation 1} \\
\hline Geometry & \multicolumn{2}{|c|}{ Situk River system with trees in Old Situk Channel } \\
\hline \multirow{4}{*}{$\begin{array}{l}\text { Boundary } \\
\text { conditions }\end{array}$} & Russell Lake outflow & Russell Lake outflow into channel with trees \\
\hline & Situk Lake outflow & $\begin{array}{l}\text { Drainage area weighted flow based on Situk River } \\
\text { gage }\end{array}$ \\
\hline & Upper Situk lateral inflow & Estimated flow based on Situk River gage \\
\hline & Pacific Ocean & Recorded daily water elevation \\
\hline \multicolumn{3}{|r|}{ Simulation 2} \\
\hline Geometry & \multicolumn{2}{|c|}{ Situk River system with no trees in Old Situk Channel } \\
\hline \multirow{4}{*}{$\begin{array}{l}\text { Boundary } \\
\text { conditions }\end{array}$} & Russell Lake outflow & Russell Lake outflow into channel with no trees \\
\hline & Situk Lake outflow & $\begin{array}{l}\text { Drainage area weighted flow based on Situk River } \\
\text { gage }\end{array}$ \\
\hline & Upper Situk lateral inflow & Estimated flow based on Situk River gage \\
\hline & Pacific Ocean & Recorded daily water elevation \\
\hline
\end{tabular}

\section{Steady flow simulation}

The flows to be expected in the Situk River were determined by the period of record simulations. Analysis of these results allowed the flow in the 
channels to be determined as a percentile of the total days of the simulations. Table 9 lists the percentile results. These results were used as the basis of a series of steady flow profiles for all the channels of the Situk River. The downstream water surface elevation selected for these profiles was 8.05 $\mathrm{ft}$ MLLW; this value was selected because it was the mean of the NOAA gage data for 1961 through 2006 and because it was the highest elevation that occurred during the period of record simulations. It was recorded on 1 November 1991, the first day of the simulations. We calculated 13 profiles, each corresponding to a percentile listed in Table 9. Two sets of profiles were calculated. The first set used the geometry of the Situk River system with trees in the channel of the Old Situk River, and the second with no trees. The results of the simulations are discussed in the next section.

Table 9. Flow percentiles in the Situk River system after closure.

\begin{tabular}{|c|c|c|c|c|c|c|}
\hline \multirow[b]{2}{*}{ Percentile } & \multicolumn{2}{|c|}{ Trees in channel } & \multicolumn{2}{|c|}{ No trees in channel } & \multirow[b]{2}{*}{$\begin{array}{l}\text { Upper Situk } \\
\text { River }\left(\mathrm{ft}^{3} / \mathrm{s}\right)\end{array}$} & \multirow[b]{2}{*}{$\begin{array}{c}\text { Situk Lake } \\
\text { outflow } \\
\left(\mathrm{ft}^{3} / \mathrm{s}\right)\end{array}$} \\
\hline & $\begin{array}{l}\text { Russell } \\
\text { Lake } \\
\text { outflow } \\
\text { (ft } 3 / \mathrm{s})\end{array}$ & $\begin{array}{l}\text { Lower Situk } \\
\text { River }\left(\mathrm{ft}^{3} / \mathrm{s}\right)\end{array}$ & $\begin{array}{l}\text { Russell } \\
\text { Lake } \\
\text { outflow } \\
\left(\mathrm{ft}^{3} / \mathrm{s}\right)\end{array}$ & $\begin{array}{l}\text { Lower Situk } \\
\text { River }\left(\mathrm{ft}^{3} / \mathrm{s}\right)\end{array}$ & & \\
\hline 10 & 4740 & 5069 & 4549 & 4852 & 112 & 44 \\
\hline 20 & 6127 & 6501 & 5858 & 6258 & 147 & 57 \\
\hline 30 & 7610 & 7994 & 7596 & 8023 & 172 & 67 \\
\hline 40 & 9336 & 9752 & 9437 & 9792 & 198 & 77 \\
\hline 50 & 11991 & 12426 & 12294 & 12623 & 229 & 89 \\
\hline 60 & 15031 & 15424 & 15152 & 15484 & 267 & 104 \\
\hline 70 & 18169 & 18408 & 18285 & 18484 & 320 & 124 \\
\hline 80 & 20604 & 20787 & 20737 & 20960 & 403 & 156 \\
\hline 90 & 23252 & 23570 & 23279 & 23598 & 580 & 223 \\
\hline 95 & 25345 & 25715 & 25418 & 25723 & 768 & 288 \\
\hline 99 & 29711 & 30555 & 29952 & 30740 & 1480 & 535 \\
\hline 99.9 & 34700 & 35596 & 34842 & 35799 & 2634 & 983 \\
\hline 100 & 37107 & 37743 & 37502 & 38161 & 3066 & 1112 \\
\hline
\end{tabular}




\section{Hydrology of the Situk River System Following Closure of Russell Fiord}

The hydrology of the Situk River system after closure of Russell Fiord by the Hubbard Glacier is based on the results of simulations of the period of record and the steady flow. We analyzed the hydraulic information provided by these simulations to determine the stream discharges, flood levels, erosion potential, and other effects of the closure of Russell Fiord.

\section{Discharges}

The expected discharges in the Situk River system after Russell Fiord closes were determined through the period of record simulation. This simulation estimated the daily flow along Upper, Lower, and Old Situk rivers for 15 years, or roughly 5200 days. First, the discharge percentiles were determined for each of the three channels (Table 9). Each percentile refers the percentage of daily flows that are equal to or less than the given amount over the simulation period. The flows range from about $4500 \mathrm{ft} 3 / \mathrm{s}$ to a maximum of approximately 38,000 $\mathrm{ft}^{3} / \mathrm{s}$. The flows in the Lower Situk River are slightly greater than the Russell Lake outflow, with the difference provided by flow out of the Upper Situk River. The percentiles were determined for both channel geometries of the Old Situk River, with and without trees growing in the channel; the channel geometry has a relatively small impact on the discharge percentiles.

Next, we determined the annual exceedance probabilities from the period of record simulation. Given the inability to estimate the probability of the closure of Russell Fiord by Hubbard Glacier, it is not possible to assign a "true" annual exceedance probability to the flows estimated. However, to provide insight into the simulation results, we determined the annual exceedance probabilities assuming that a sustained closure had occurred, an event of unknown probability. The annual exceedance probabilities are presented only in this section of the report. In the remainder of the report, the discharges are described in terms of percentiles rather than annual exceedance probabilities.

We determined the annual exceedance probabilities using the following steps. First, the annual maximum flows produced by the period of record 
simulation were selected for three locations (Russell Lake outflow, Upper Situk River, and Lower Situk River) for both channel geometries of the Old Situk River. This produced 15 values covering 1991 through 2005. Next, the annual probabilities were determined using the methodology described in Bulletin 17B (U.S. Geological Survey 1982), which is the basis of the Statistical Software Package HEC-SSP (U.S. Army Corps of Engineers 2008). Not all of the annual maximums were used. The first-year maximum produced by the simulation was identified as a "low outlier" according to the Bulletin 17B criteria and was not included in the final analysis. As noted above, Russell Lake was filling during the first year of the simulation, and the low outflow reflected this. The station skew coefficient was assumed to be zero in all cases. Table 10 lists the overall results. The estimated annual exceedance probability curves for the Russell Lake outflows for case of the channel with trees are shown in Figure 29 and for the case of the channel without trees in Figure 30.

It is interesting to note that the maximum daily flows during the period of record simulation (100 ${ }^{\text {th }}$ percentile in Table 9 ) are close to the $2 \%$ exceedance probability (50-year return period) for the Russell Lake outflow and the Lower Situk River flow for both geometries. Generally, unless some rare and specific event is included in the simulation, the maximum daily flow produced in a period of record simulation should have a return period roughly equal to the length of the simulation period. That is, we would expect the maximum flow in this simulation to have roughly a 15-year return period. The cause of the discrepancy is not clear. The large control and significant attenuation produced by Russell Lake act to "flatten" the annual probability curve (Fig. 29 and 30) by effectively reducing the standard deviation of the series of annual maximums. The result is difficulty in matching return periods because a small range of flows spans a relatively large range of return periods.

The percentiles of the flows of the Upper Situk and the outlet of Situk Lake are listed in Table 9; the annual exceedance probabilities are listed in Table 10 and displayed in Figures 31 and 32. In both cases, the flow with an annual exceedance probability of 5\% (20-year return period) roughly matches the $100 \%$ flow percentile of the 15-year simulation. In this case, there is a relatively good match between the return period of the maximum flow and the 15-year length of the simulation period. 
Table 10. Annual exceedance probabilities for the Situk River system after closure.

\begin{tabular}{|c|c|c|c|c|c|c|}
\hline \multirow{2}{*}{$\begin{array}{c}\text { Percent } \\
\begin{array}{c}\text { Chance } \\
\text { Exceedance }\end{array}\end{array}$} & $\begin{array}{c}\text { Russell } \\
\text { Lake } \\
\text { outflow } \\
\left(\mathrm{ft}^{3} / \mathrm{s}\right)\end{array}$ & $\begin{array}{c}\text { Lower } \\
\text { Situk River } \\
\left(\mathrm{ft}^{3} / \mathrm{s}\right)\end{array}$ & $\begin{array}{c}\text { Russell } \\
\text { Lake } \\
\text { outflow } \\
\left(\mathrm{ft}^{3} / \mathrm{s}\right)\end{array}$ & $\begin{array}{c}\text { Lower } \\
\text { Situk River } \\
\left(\mathrm{ft}^{3} / \mathrm{s}\right)\end{array}$ & $\begin{array}{c}\text { Upper } \\
\text { Situk River } \\
\left(\mathrm{ft}^{3} / \mathrm{s}\right)\end{array}$ & $\begin{array}{c}\text { Flow out of } \\
\text { Situk Lake } \\
\left(\mathrm{ft}^{3} / \mathrm{s}\right)\end{array}$ \\
\hline 0.2 & 40,470 & 41,484 & 41,084 & 42,144 & 5,128 & 1,934 \\
\hline 0.5 & 39,068 & 40,043 & 39,631 & 40,649 & 4,555 & 1,720 \\
\hline 1 & 37,947 & 38,892 & 38,471 & 39,456 & 4,134 & 1,562 \\
\hline 2 & 36,759 & 37,672 & 37,242 & 38,192 & 3,720 & 1,407 \\
\hline 5 & 35,046 & 35,914 & 35,473 & 36,372 & 3,179 & 1,203 \\
\hline 10 & 33,592 & 34,420 & 33,971 & 34,828 & 2,768 & 1,048 \\
\hline 20 & 31,911 & 32,695 & 32,237 & 33,045 & 2,344 & 888 \\
\hline 50 & 28,927 & 29,631 & 29,163 & 29,885 & 1,713 & 649 \\
\hline 80 & 26,221 & 26,854 & 26,382 & 27,028 & 1,259 & 476 \\
\hline 90 & 24,909 & 25,508 & 25,036 & 25,644 & 1,075 & 406 \\
\hline 95 & 23,876 & 24,448 & 23,976 & 24,555 & 944 & 356 \\
\hline 99 & 22,051 & 22,575 & 22,107 & 22,636 & 742 & 279 \\
\hline
\end{tabular}

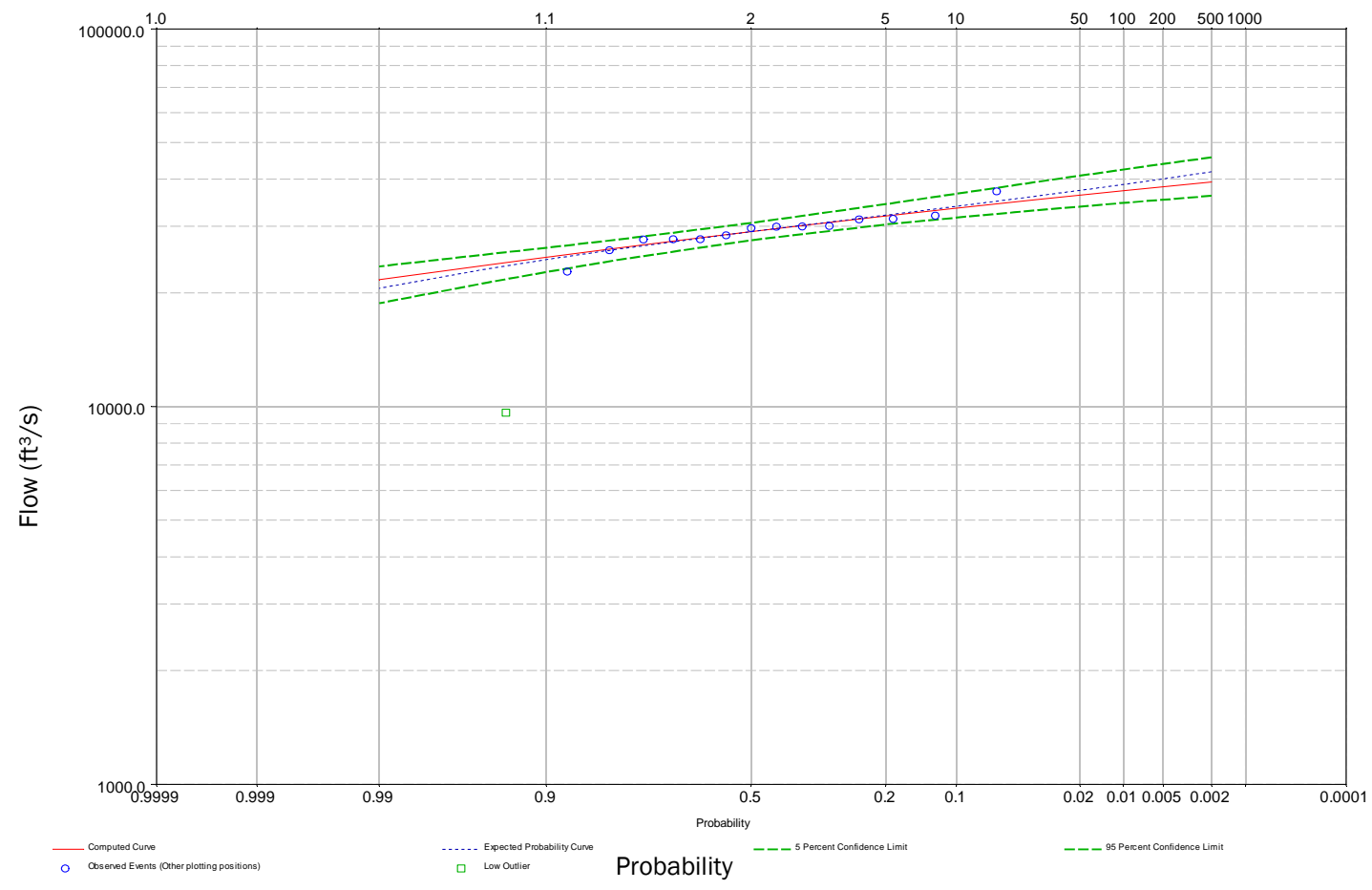

Figure 29. Exceedance probabilities for the Russell Lake outflow channel with trees. The lowest annual maximum was identified as an "low outlier" and not included in the analysis. 


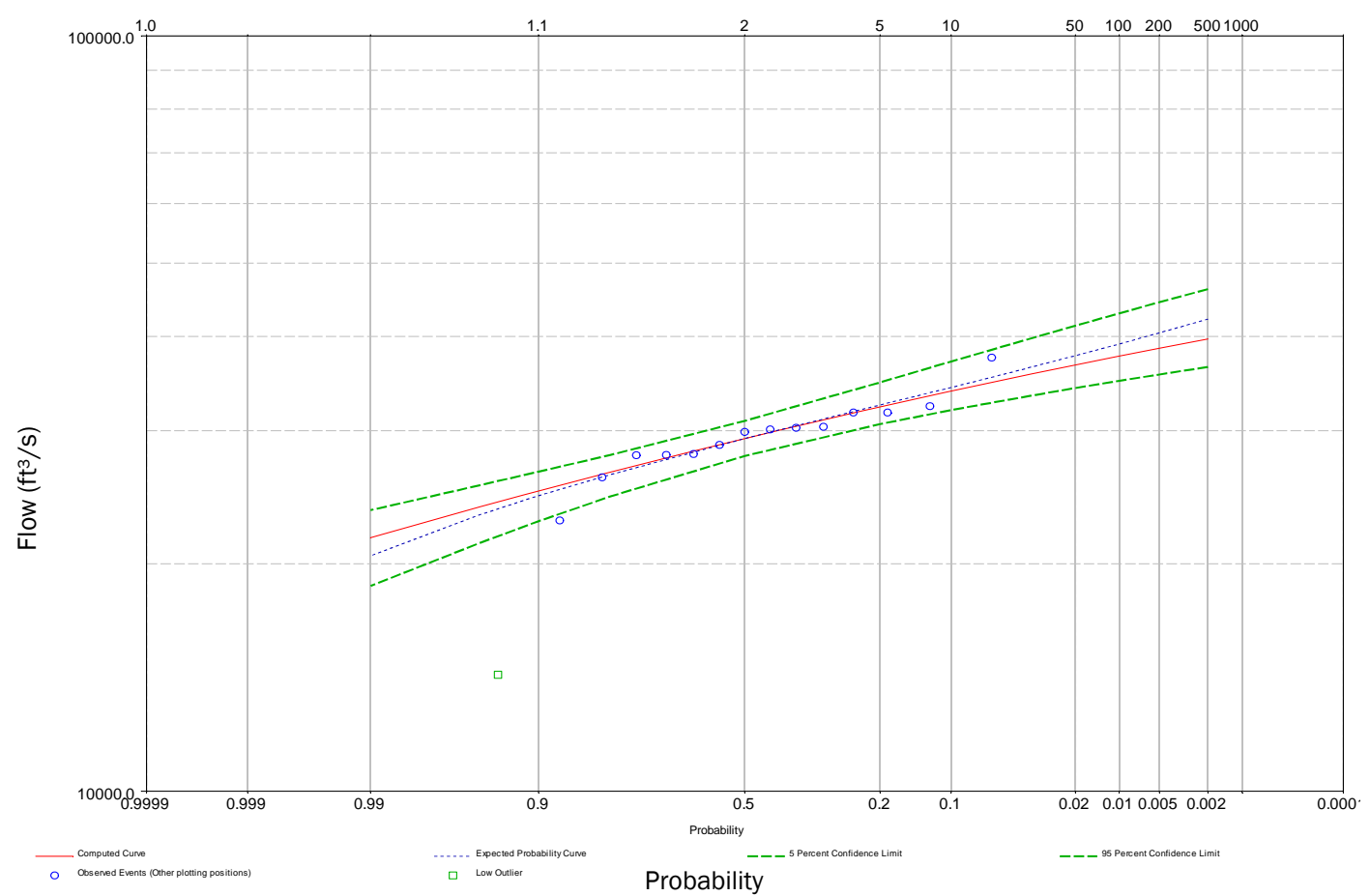

Figure 30. Exceedance probabilities for the Russell Lake outflow channel with no trees. The lowest annual maximum was identified as an "low outlier" and not included in the analysis.

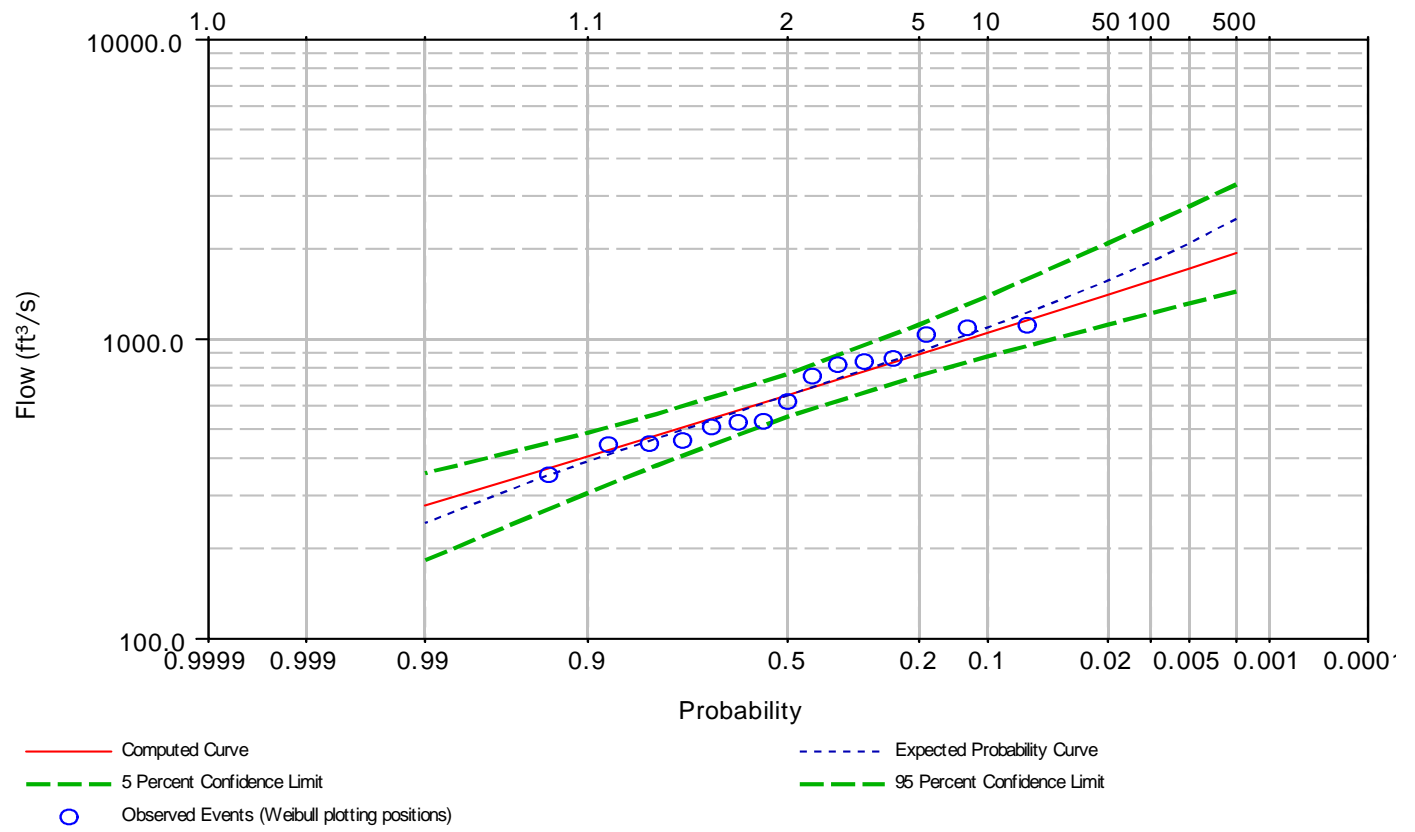

Figure 31. Exceedance probabilities for the Situk Lake outflow. 


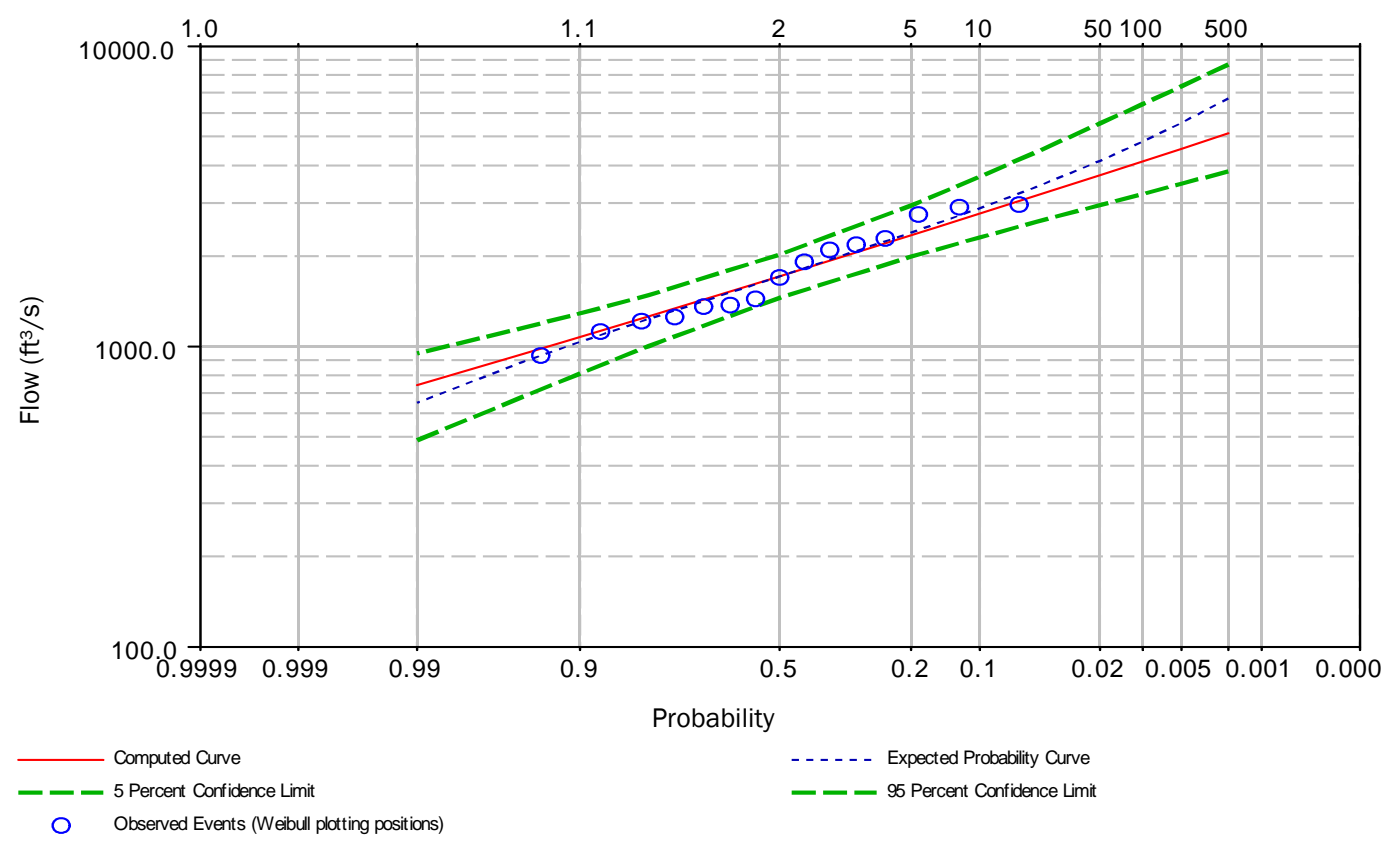

Figure 32. Exceedance probabilities for the Upper Situk River discharge.

The daily average flows in the Lower Situk River after closure can also be estimated based on the period of record simulation. These results are shown in Figures 33 and 34. The flows in the Situk River would be about 35 times larger than now, reflecting the massive increase in the size of the Situk River watershed following closure. The flows in the Situk River would peak a bit earlier in the year, in late August instead of late September and into October as now. The minimum flows would occur in spring, with the lowest flows in J anuary through April. 


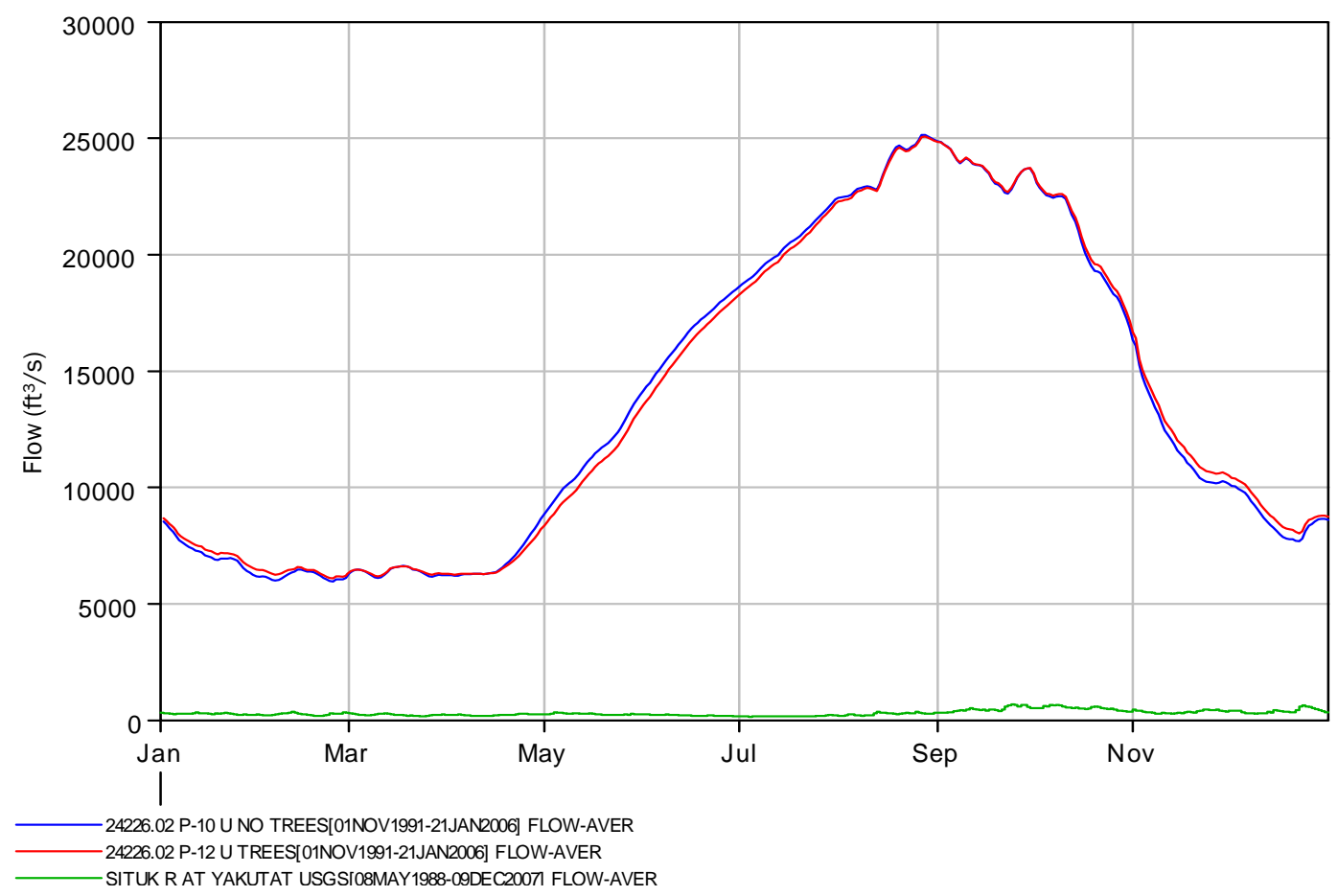

Figure 33. Daily average flow in the Situk River after closure (red and blue) compared to existing conditions (green).

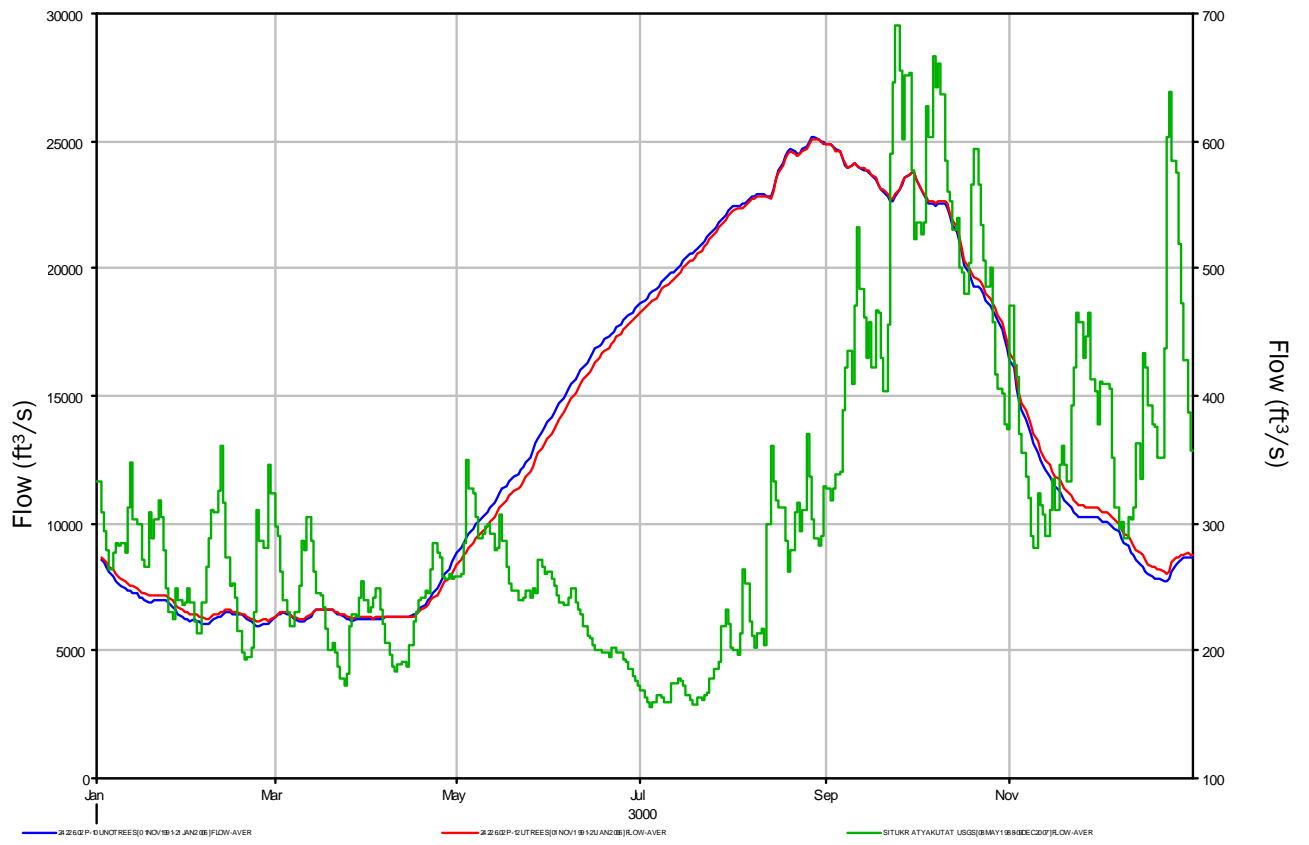

Figure 34. Daily average flow in the Situk River before closure (green, right axis) and after closure (red and blue, left axis). 


\section{Flood levels}

The flood levels were determined using the $100^{\text {th }}$ percentile flows listed in Table 9. As discussed above, the $100^{\text {th }}$ percentile flows were larger than or nearly as large as all the flows with an annual exceedance of $0.2 \%$ or greater, resulting from the large attenuation caused by Russell Lake on the inflows into the Old Situk River. This suggests that the $100^{\text {th }}$ percentile flows are a more conservative choice to use in the flood analysis. Flood inundation maps (Fig. 35 and 36) were prepared using the steady flow simulation results for the $100^{\text {th }}$ percentile flows listed in Table 9. There is little difference between the two maps except in the upper reach of the Old Situk River, which is as expected. It is not expected that the Yakutat Airport would be inundated at these flow levels. There would be large inundated areas directly west of the Situk River, corresponding to low elevation areas.

\section{Potential for erosion}

We investigated the potential for erosion by determining the effective channel shear stress that would occur throughout the Situk River system. This shear stress was then assessed by the known critical shear stress required to initiate motion of different sizes of material present in the channel (silt, sand, gravel, cobbles, boulders, etc.). Finally, the results of the geotechnical investigation of the Old Situk Channel (R\&M Consultants, Inc. 2006) were reviewed to determine the type and size of material located in the reaches with the highest expected shear stress.

This effective shear stress, or tractive force, that would act on the channel bed can be estimated as

$$
\tau_{\mathrm{o}}=\rho \mathrm{gRS}
$$

where $\tau_{0}=$ shear stress per unit wetted area

$\rho=$ density of water

$\mathrm{g}=$ gravity

$\mathrm{R}=$ hydraulic radius

$\mathrm{S}=$ slope of the energy grade line. 


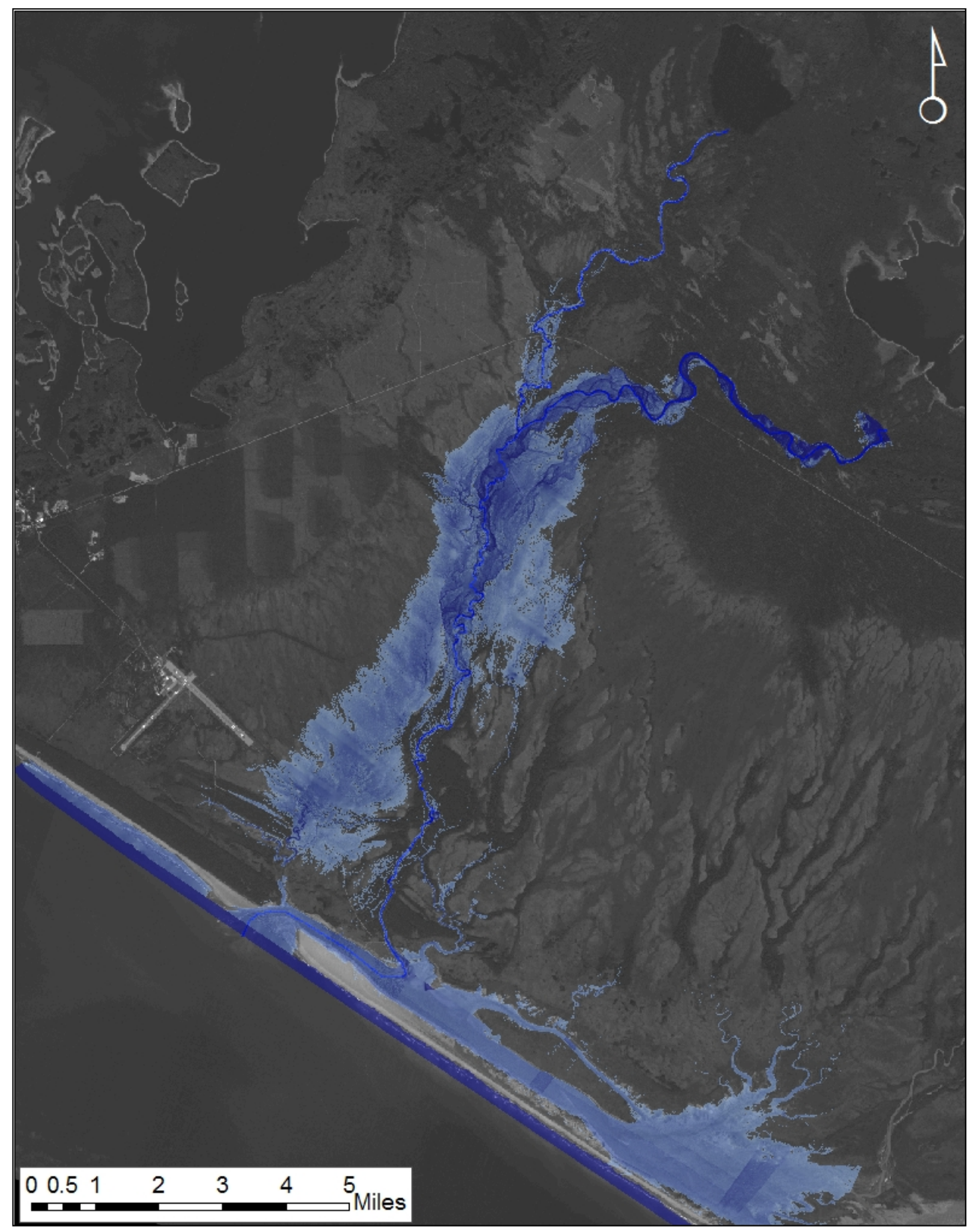

Figure 35. Flood inundation map of the Situk River for the case when there are no trees in the Old Situk channel. The flow depth is indicated by the shade of blue: the darker the shade, the greater the flow depth. 


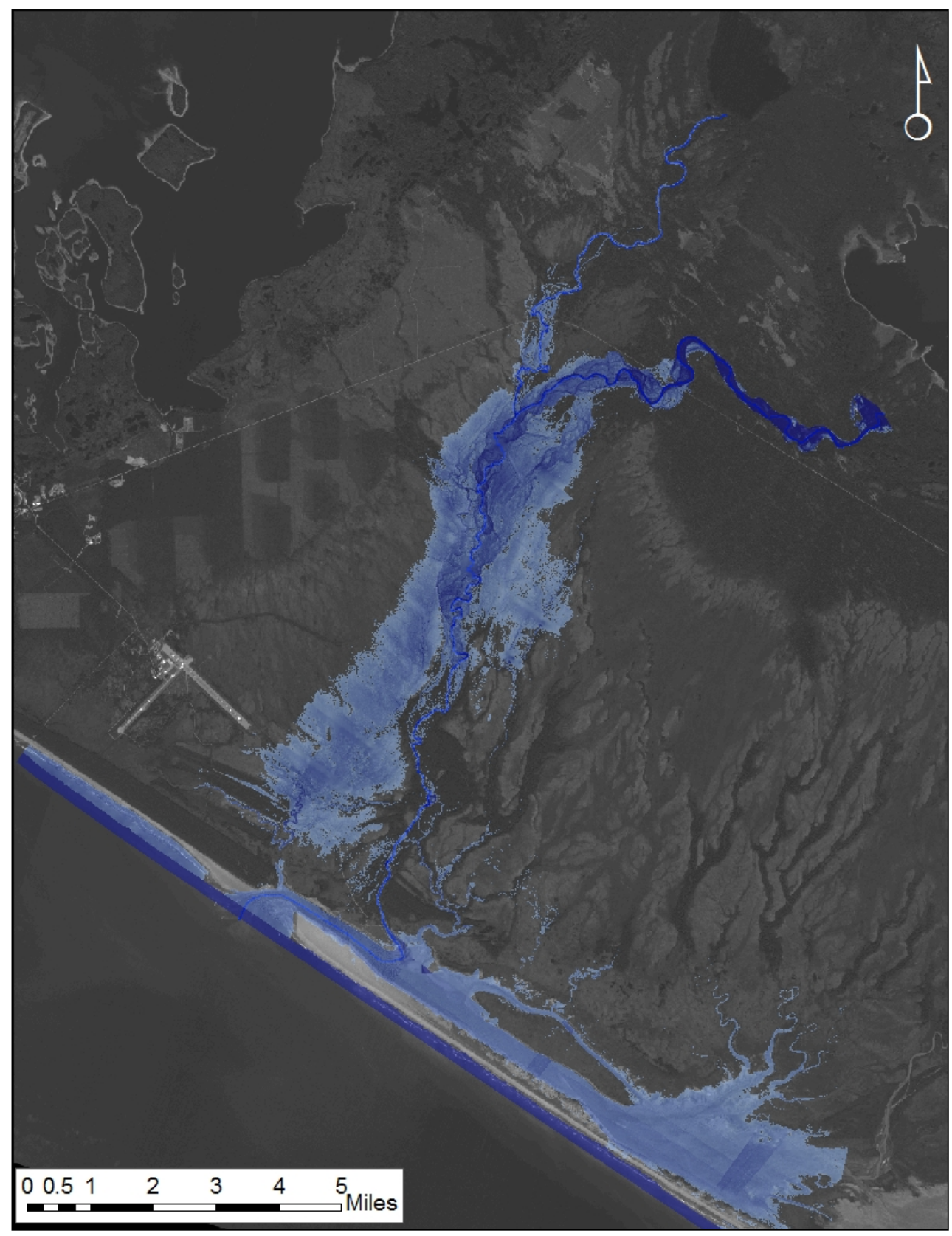

Figure 36. Flood inundation map of the Situk River for the case when there are trees in the Old Situk channel. The flow depth is indicated by the shade of blue: the darker the shade, the greater the flow depth.

The shear stress values for each percentile of flow are shown in Figure 37 for the Old Situk River and Figure 38 for the Upper and Lower Situk Rivers. The river reaches with the highest shear stress, and therefore the highest erosion potential, are shown in Figure 39; these reaches all occur in the Old Situk River. The critical shear stresses for a wide range of materials are listed in Table 11 (J ulien 1995). The maximum shear stresses estimated for the Notch area of the Old Situk are quite large, on the order of 
$8 \mathrm{lb} / \mathrm{ft}^{2}$, large enough to move small to medium boulders with diameters up to $20 \mathrm{in}$. This must be assessed against the actual material occurring in the Old Situk River channel as determined through geotechnical investigation of the Old Situk Channel (R\&M Consultants, Inc. 2006). The drilling log of a core taken in the Old Situk Channel at a reach near where the maximum shear stress is expected (Fig. 40) indicated "Nested cobbles and boulders" very near the surface. Unfortunately "it was not possible to determine the amount or maximum size of cobbles or boulders encountered during the drilling program due to the type of equipment used" (R\&M Consultants Inc. 2006). In addition, "....glacial erratics to 10 feet or more in diameter were observed on the surface near the borings" and "nested cobbles and boulders were particularly present in the alluvial material at the bottom of the 'Notch'." The results of the geotechnical investigation certainly suggest that these high shear stress reaches of the Notch experienced flow in the past and that the channel bed may have become armored as a result. However, without further investigation, it is not possible to estimate the erosion resistance ability of the reaches of the Old Situk River that are expected to undergo high shear stress.

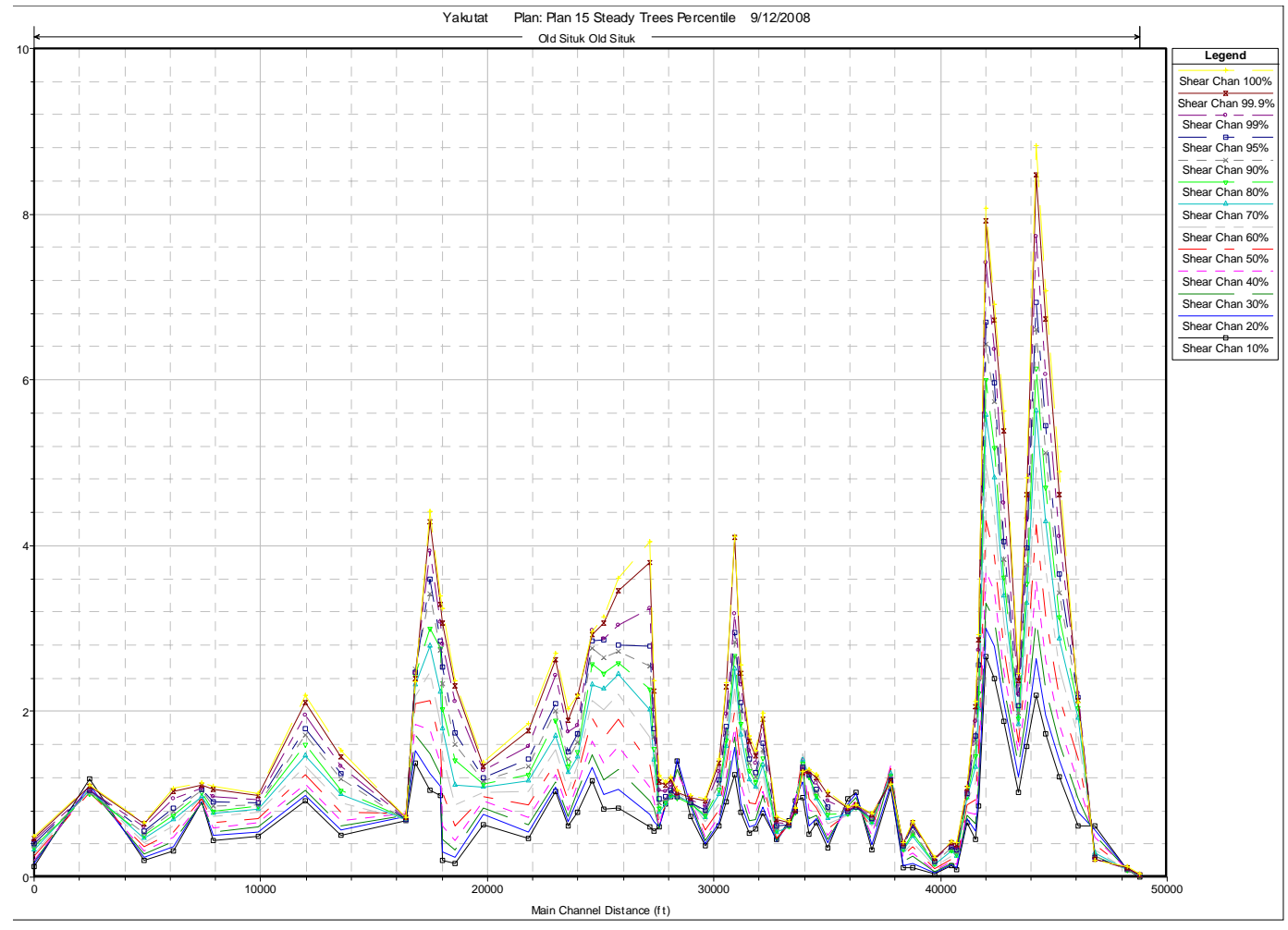

Figure 37. Channel shear stress in the Old Situk River channel for each percentile of flow. The distances shown are the lengths along the channel from the downstream confluence with the Upper Situk River. 


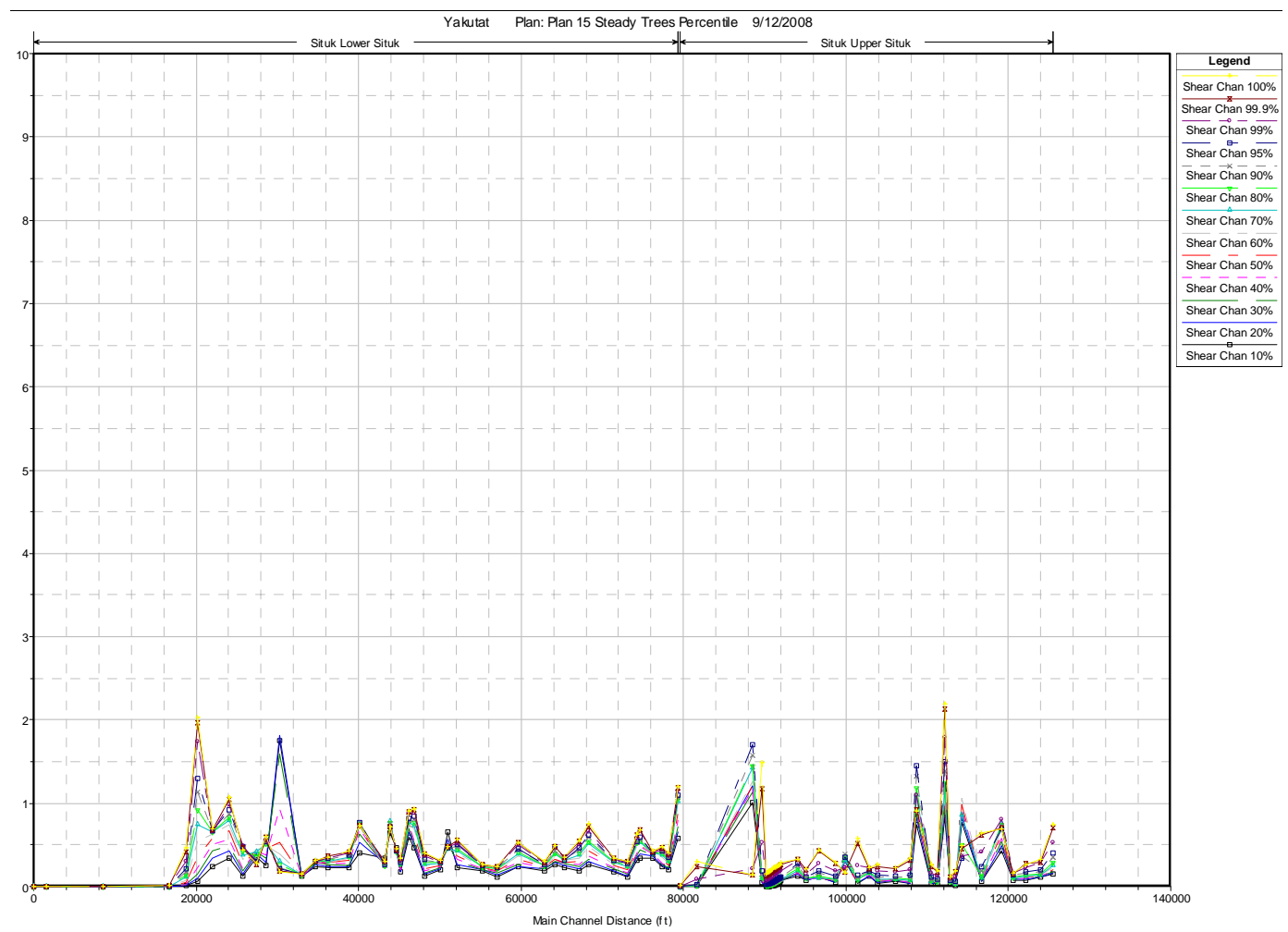

Figure 38. Channel shear stress in the Upper and Lower Situk Rivers for each percentile of flow. The distances shown are the lengths along the channel from the downstream confluence with the Pacific Ocean.

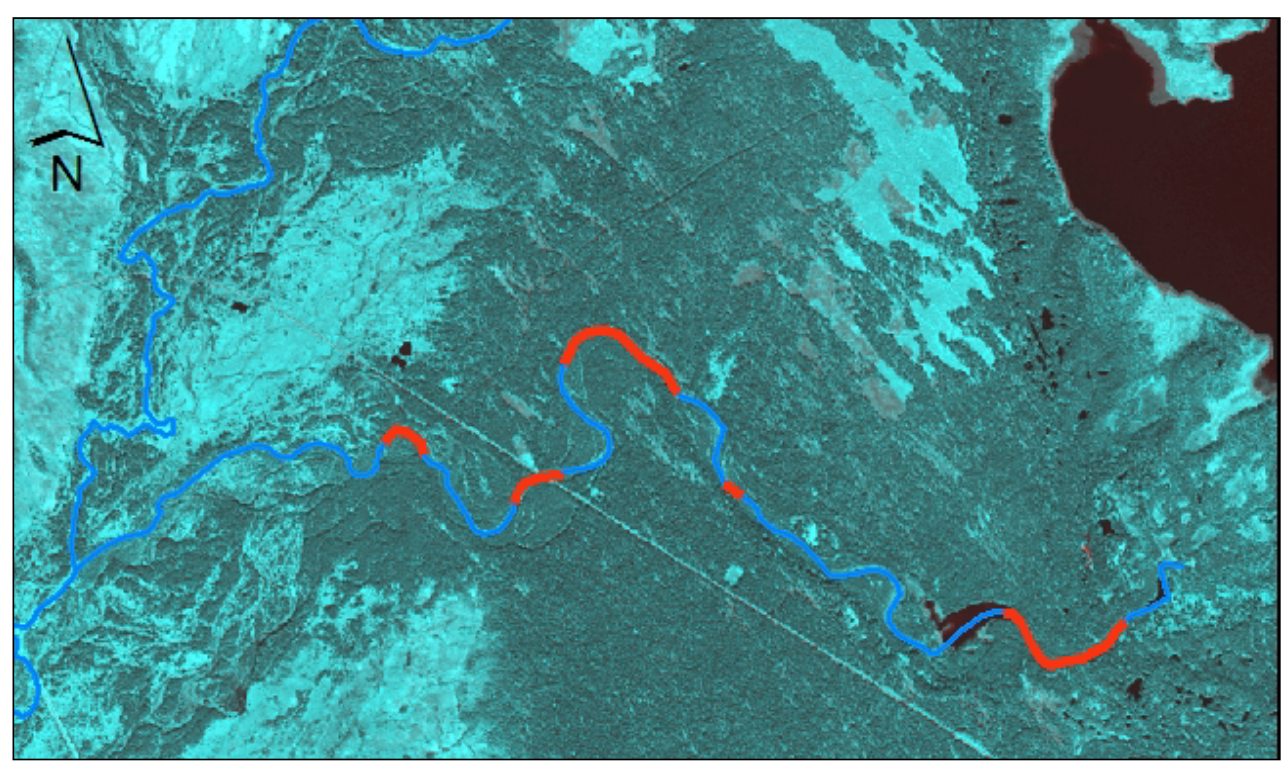

Figure 39. Potential erosion reaches (shown in red) in the Old Situk River. This view is of the Old Situk River. The Upper Situk River is visible on the left, and Russell Fiord is visible in the upper right. 
Table 11. Critical shear stress for bed material (after Julien 1995).

\begin{tabular}{|c|c|c|}
\hline Class & $\begin{array}{l}\text { Minimum size } \\
\text { (in.) }\end{array}$ & $\begin{array}{c}\text { Critical shear } \\
\left(\mathrm{lb} / \mathrm{ft}^{2}\right)\end{array}$ \\
\hline \multicolumn{3}{|c|}{ Boulders } \\
\hline Very large & 80.63 & 37.38 \\
\hline Large & 40.31 & 18.69 \\
\hline Medium & 20.16 & 9.34 \\
\hline Small & 10.08 & 4.66 \\
\hline \multicolumn{3}{|c|}{ Cobbles } \\
\hline Large & 5.04 & 2.32 \\
\hline Small & 2.52 & 1.11 \\
\hline \multicolumn{3}{|c|}{ Gravels } \\
\hline Very coarse & 1.26 & 0.54 \\
\hline Coarse & 0.63 & 0.25 \\
\hline Medium & 0.31 & 0.12 \\
\hline Fine & 0.16 & 0.06 \\
\hline Very fine & 0.08 & 0.026 \\
\hline \multicolumn{3}{|c|}{ Sand } \\
\hline Very coarse & 0.0394 & 0.0098 \\
\hline Coarse & 0.0020 & 0.0056 \\
\hline Medium & 0.0098 & 0.0041 \\
\hline Fine & 0.0049 & 0.0030 \\
\hline Very fine & 0.0025 & 0.0023 \\
\hline \multicolumn{3}{|c|}{ Silt } \\
\hline Coarse & 0.0012 & 0.0017 \\
\hline Medium & 0.0006 & 0.0014 \\
\hline
\end{tabular}




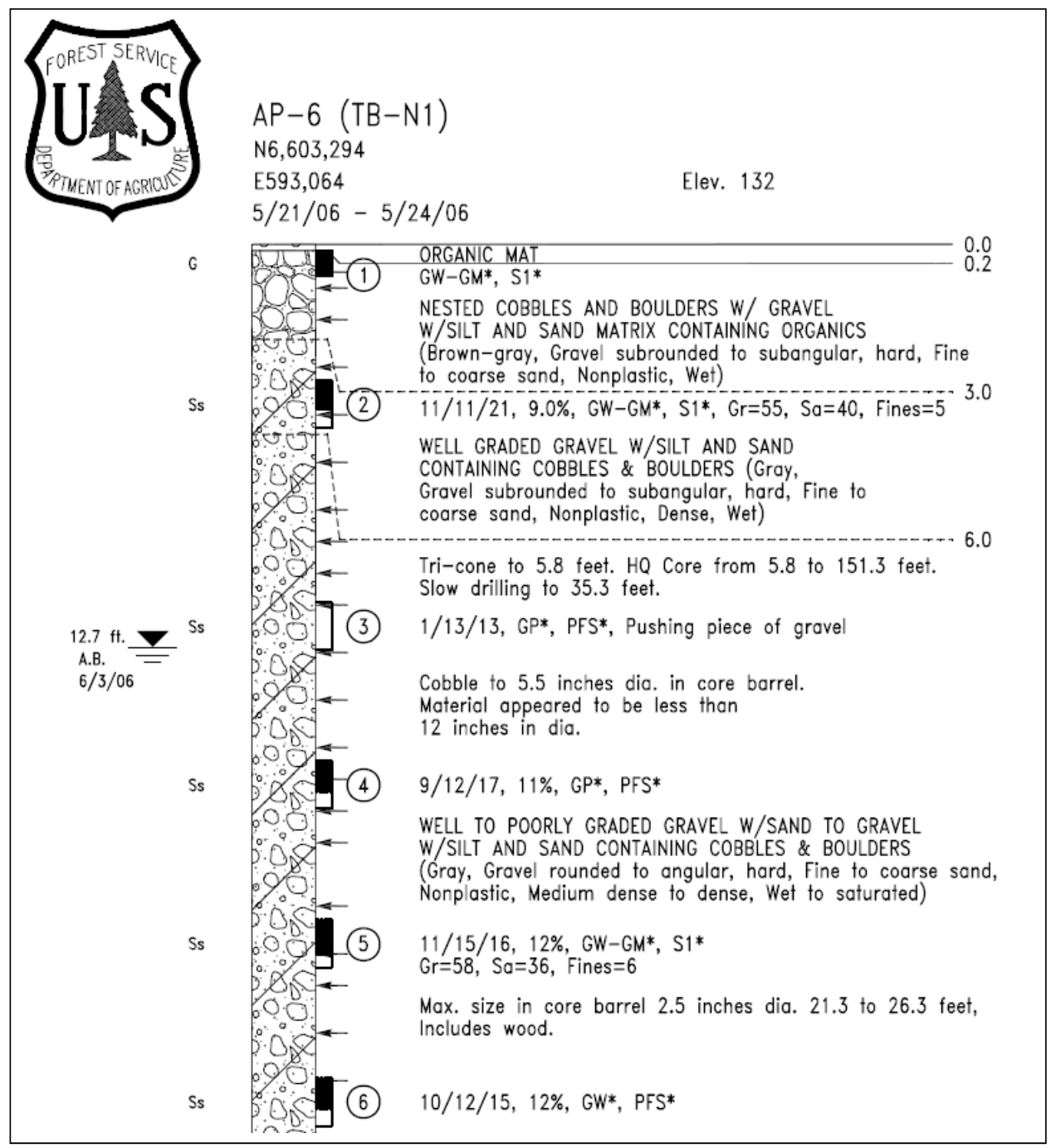

Figure 40. Drill log of core taken in Old Situk Channel (R\&M Consultants, Inc. 2006).

\section{Other impacts}

\section{Old Situk River road crossing}

The road crossing over the Old Situk includes five 6-ft culverts beneath the roadway near the stream invert. The steady flow simulations are shown in Figure 41, assuming that the culverts are clear of sediment. Each profile corresponds to a flow percentile listed in Table 9. The capacity of the culverts in this crossing will quickly be overwhelmed by the Russell Lake outflows, as even the $10^{\text {th }}$ percentile flow overtops the roadway. This crossing will have to be relocated or rebuilt if this road is to be kept open. It was noted during a site visit in late September 2007 that the culverts appeared to be half filled with sediment. Therefore, it can be expected that the roadway will be overtopped at very low flows. 


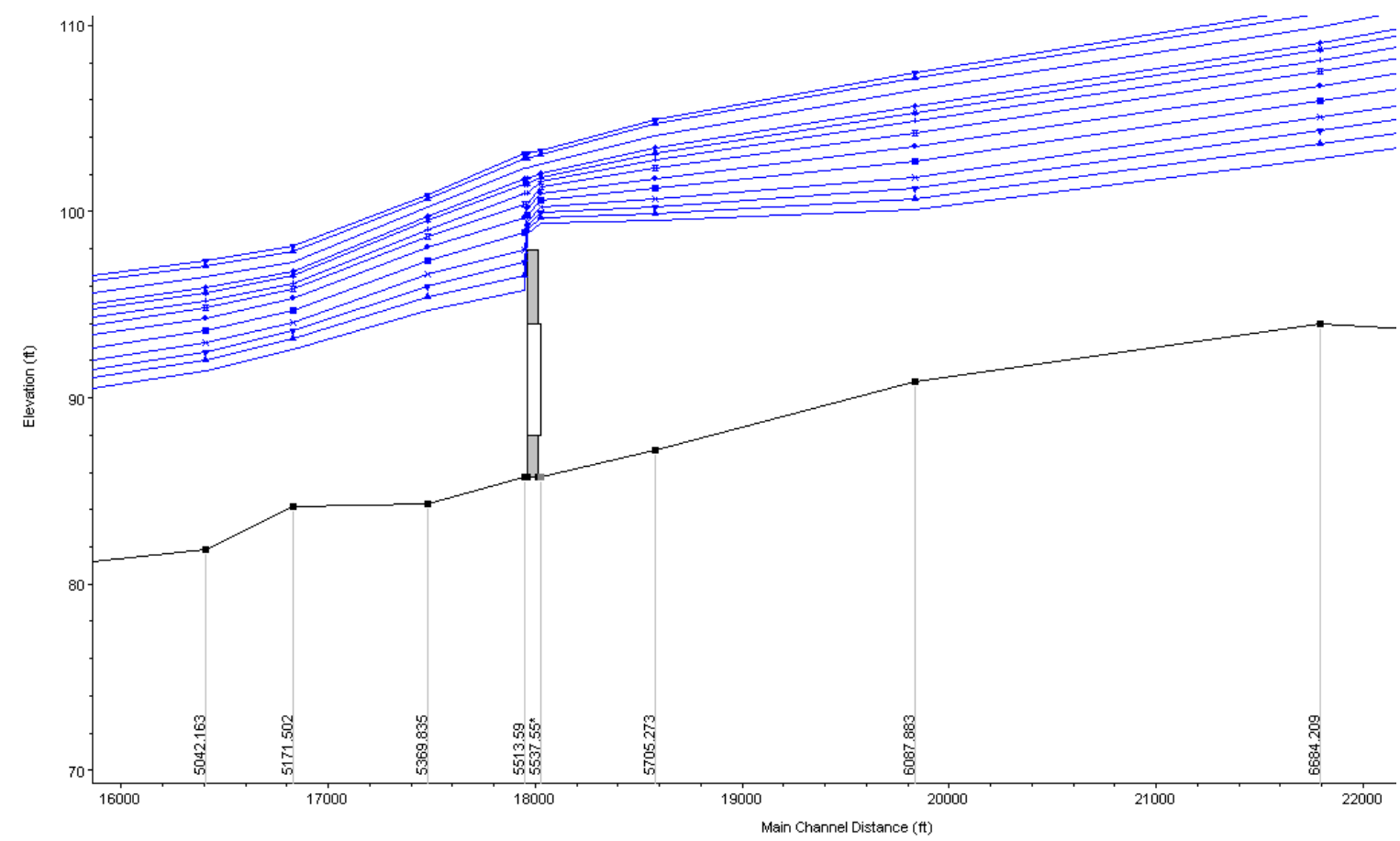

Figure 41. Flood profiles at the Old Situk River road crossing.

\section{Situk Lake}

Situk Lake, located at the upstream end of the Upper Situk River, will not be affected by the outflows from Russell Lake. The outlet of the lake is approximately $80 \mathrm{ft}$ above the confluence of the Upper Situk River and the Old Situk River. The steady flow profiles (not shown) indicate that the backwater influence caused by the Russell Lake outflows will not have an influence at the outlet.

\section{Channel migration}

As shown in the inundation maps (Fig. 35 and 36), there is a large area west of the Situk River that is at a low elevation compared to the Situk River itself. There exists a potential for the Lower Situk River to migrate to this low elevation area during periods of high flows.

\section{Log jams}

Logjams could occur along the Old Situk River and Lower Situk River after the outflow from Russell Lake commences and the flow in these rivers increases dramatically. Water levels immediately upstream of log jams will increase and exacerbate flooding. There may be increased erosion in the channel bed and banks as the water flows around and under logjams. It is 
impossible to predict where logjams could occur. Logjams in the upper reaches of the Old Situk may, for a time, reduce the outflows from Russell Lake, raising the level of the lake. The outflows are determined largely by the inflows into Russell Lake, as was shown in the Old Situk River Inflows section. As a result, logjams in the upper section of the Old Situk River should not influence discharges into the Old Situk River over the long term. Logjams in the lower section of the Old Situk River could cause significant additional flooding in the immediate area. Logjams in the Lower Situk River are likely to redirect flows out of the Lower Situk River main channel and down alternate low-lying areas. As a result, significant flooding should not result from logjams in the Lower Situk River. 


\section{Summary}

It is not now possible to quantify with any certainty the probability of closure of Russell Fiord for an extended period by Hubbard Glacier. However, given the more-or-less continuous advance of the glacier since 1895, it seems likely that the probability is significant. This report looks beyond the closure of Russell Fiord to describe the likely hydrology of the Situk River once a sustained closure has occurred.

We developed a hydrological model describing the inflows into Russell Lake and estimated the inflows into Russell Lake over 15 years. These inflows, when routed through Russell Lake, determine the inflows into the Old Situk River. The annual statistics for the estimated inflows were compared to the USGS regression equation estimates of the annual statistics for ungaged basins in Alaska, with good results.

A HEC-RAS one-dimensional flow model was developed to estimate the levels and flows of the Situk River system, including the Old Situk, Upper Situk, and Lower Situk rivers. The channel geometry was based on an extensive LiDAR survey of the Situk River watershed conducted using NASA's Airborne Topographic Mapper in August and September 2005. The LiDAR data were processed and analyzed to provide cross sections for the HEC-RAS model. The HEC-RAS results were compared to the observed stages and discharges at the USGS gage on the Upper Situk, with reasonable results.

The estimated inflows into Russell Lake were routed through the lake using the level-pool continuity equation. This routing strongly attenuated rapid changes in the inflows.

We simulated the levels and flows in the Situk River system over 15 years, using the estimated outflows from Russell Lake, to determine the statistics of the system's hydrology. The flow percentiles, annual exceedance probabilities, and average daily flows were estimated.

A series of steady flow profiles were then determined using discharges and boundary conditions based on the results of the 15-year simulation. These profiles were used to develop inundation maps and investigate potential 
channel erosion, the effects on the Old Situk River crossing and Situk Lake, and the potential effects of logjams and channel migration.

The inundation maps indicate that the Yakutat Airport is unlikely to be flooded.

Reaches with large erosion potential were identified in the Old Situk River. The geotechnical investigation conducted previously noted the presence of "nested cobbles and boulders" very near the surface in this area. It is not clear if the existing bed material will be sufficient to protect the bed from erosion in these reaches. 


\section{References}

Alaska Department of Fish and Game. 2009. Yakutat area sport fisheries. http:/ / www.sf.adfg.state.ak.us/ Management/Areas.cfm/ FA/ yakFish.fishInfo

Arcement, G. J., J r., and V. R. Schneider. 1984. Guide for selecting Manning's roughness coefficients for natural channels and flood plains. Rep. No. FHWA-TS-84-204. Washington, D.C.: U.S. Department of Transportation, Federal Highway Administration.

Arendt, A. A., K. A. Echelmeyer, W. D. Harrison, C. S. Lingle, and V. B. Valentine. 2002. Rapid wastage of Alaska glaciers and their contribution to rising sea level. Science 297(5580):382-386.

Barclay, D. J ., P. E. Calkin, and G. C. Wiles. 2001. Holocene history of Hubbard Glacier in Yakutat Bay and Russell Fiord, southern Alaska. Geological Society of America Bulletin 113:388-402.

Barnes, H. H., Jr. 1967. Roughness characteristics of natural channels. Water-Resources Paper 1849. Washington, D.C.: U.S. Geological Survey.

Chow, V. T. 1959. Open channel hydraulics. New York: McGraw-Hill.

Chow, V. T., D. R. Maidment, and L. W. Mays. 1988. Applied hydrology. New York: McGraw-Hill.

Curran, J . H., D. F. Meyer, and G. D. Tasker. 2003. Estimating the magnitude and frequency of peak streamflows for ungaged sites on streams in Alaska and conterminous basins in Canada. Water-Resources Investigations Report 034188. Anchorage, AK: U.S. Geological Survey.

Echelmeyer, K. A., W. D. Harrisson, C. F. Larsen, J . Sapino, J . E. Mitchell, J . DeMallie, B. Rabus, G. Adalgeirsdottir, and L. Sombardier. 1996. Airborne surface profiling of glaciers: A case study in Alaska. J ournal of Glaciology 42(142):538- 547.

Finnegan, D. C, D. E. Lawson, G. Hanlon, and G. Kalli. 2007. Near realtime monitoring of tidewater glacier advance and retreat: Hubbard Glacier, Southeast Alaska. Eos, Transactions of the American Geophysical Union 88(52), Fall Meeting Supplement, Abstract C41A-0058.

Hock, R. 2003. Temperature index melt modeling in mountain areas. J ournal of Hydrology 282:104- 115.

Julien, P. Y. 1995. Erosion and sedimentation. Cambridge, U.K.: Cambridge University Press.

Kalli, G. A. 2005. Hubbard Glacier advances despite global warming. World Water and Environmental Resources Congress 2005 (R. Walton, ed.), 15- 19 May, Anchorage, AK. 
Krabill W., W. Abdalati, E. Frederick, S. Manizade, C. Martin, J. Sonntag, R. Swift, R. H. Thomas, W. Wright, and J . Yungel. 2000. Greenland ice sheet: High-elevation balance and peripheral thinning. Science 289:428-430

Krabill, W., E. Hanna, P. Huybrechts, W. Abdalati, J . Cappelen, B. Csatho, E. Frederick, S. Manizade, C. Martin, J. Sonntag, R. Swift, R. Thomas, and J . Yungel. 2004. Greenland Ice Sheet: Increased coastal thinning. Geophysical Research Letters 31:L24402.

Larsen, C. F., R. J . Motyka, J . T. Freymueller, K. A. Echelmeyer, and E. R. Ivins. 2005. Rapid viscoelastic uplift in southeast Alaska caused by post-Little Ice Age glacial retreat. Earth and Planetary Science Letters 237:548- 560.

Larsen, C. F., R. J . Motyka, A. Arendt, and K. A. Echelmeyer. 2007. Glacier changes in southeast Alaska and northwest British Columbia and contribution to sea level rise. J ournal of Geophysical Research 112: F01007.

Miles, M (2004) Preliminary Hydrology and Hydraulics of a Potential Russell Fiord Overflow. Alaska Department of Transportation and Public Facilities. May 2004

Musleh, F. A., and J . F. Cruise. 2006. Functional relationships of resistance in wide flood plains with rigid unsubmerged vegetation. ASCE J ournal of Hydraulic Engineering 132 (2):163- 171.

Neal, E. G. 2004. Simulated peak inflows for glacier dammed Russell Fiord, near Yakutat, Alaska, 2004. Scientific Investigations Report 2004-5234. Anchorage, AK: U.S. Geological Survey.

Neal, E. G. 2009. Personal communication. Anchorage, AK: U.S. Geological Survey.

R\&M Consultants, Inc. 2006. Geotechnical investigation, Yakutat flood damage reduction, Yakutat, Alaska. Contract No. W911KB-05-D-0004. Prepared for U.S. Army Engineer District, Alaska, Elmendorf AFB, AK.

Stone, B. M., and H. T. Shen. 2002. Hydraulic resistance of flow in channels with cylindrical roughness. ASCE J ournal of Hydraulic Engineering 128(5):500- 506.

Trabant, D. C., R. M. Krimmel, K. A. Echelmeyer, S. Zirnheld, and D. Elsberg. 2003. The slow advance of a calving glacier: Hubbard Glacier, Alaska. Annals of Glaciology 36:45- 50 .

U.S. Army Corps of Engineers. 1998. Runoff from snowmelt. Engineer Manual EM 11102-1406. Washington, D.C.: U.S. Army Corps of Engineers. http:/ / 140.194.76.129/ publications/ eng-manuals/ em1110-2-1406/toc.htm

U.S. Army Corps of Engineers. 2002. HEC-RAS River Analysis System, Hydraulic reference manual, Version 3.1. Davis, CA: Hydrologic Engineering Center.

U.S. Army Corps of Engineers. 2005. Section 905(b) (WRDA 86) analysis, Yakutat Flood damage reduction, Yakutat, Alaska. Anchorage, AK: Alaska District, U.S. Army Corps of Engineers.

U.S. Army Corps of Engineers. 2008. HEC-SSP statistical software package, Version 1. Davis, CA: Hydrologic Engineering Center. 
U. S. Geological Survey. 1982. Guidelines for determining flood flow frequency. Bulletin 17B of the Hydrology Subcommittee, Revised September 1981; Editorial

Corrections March 1982. Reston, VA: Interagency Advisory Committee on Water Data 


\section{Appendix A: Cross Section Information}

Table A1. Old Situk River cross sections.

\begin{tabular}{|c|c|c|c|c|}
\hline River station & $\begin{array}{l}\text { Length left } \\
\text { (ft) }\end{array}$ & $\begin{array}{l}\text { Length channel } \\
\text { (ft) }\end{array}$ & $\begin{array}{l}\text { Length right } \\
\text { (ft) }\end{array}$ & $\begin{array}{l}\text { Minimum } \\
\text { channel } \\
\text { elevation } \\
\text { (ft) MLLW }\end{array}$ \\
\hline 14911.610 & 500.0 & 534.1 & 460.1 & 133.3 \\
\hline 14748.800 & 1490.7 & 1432.3 & 1393.8 & 136.3 \\
\hline 14312.250 & 740.2 & 768.0 & 764.5 & 137.2 \\
\hline 14078.180 & 861.0 & 822.1 & 818.2 & 133.1 \\
\hline 13827.610 & 595.5 & 573.6 & 550.2 & 134.1 \\
\hline 13652.770 & 446.0 & 426.2 & 373.2 & 133.4 \\
\hline 13522.870 & 358.0 & 400.1 & 405.0 & 129.8 \\
\hline 13400.920 & 439.5 & 400.7 & 361.7 & 128.8 \\
\hline 13278.800 & 951.4 & 657.9 & 466.8 & 128.4 \\
\hline 13078.260 & 243.1 & 389.0 & 435.8 & 126.9 \\
\hline 12959.700 & 353.0 & 366.1 & 445.6 & 124.4 \\
\hline 12848.120 & 283.9 & 318.9 & 402.9 & 122.3 \\
\hline 12750.920 & 130.5 & 171.3 & 204.4 & 120.1 \\
\hline 12698.700 & 288.9 & 351.2 & 421.5 & 120.8 \\
\hline 12591.670 & 407.0 & 459.9 & 531.4 & 120.9 \\
\hline 12451.490 & 392.5 & 229.0 & 209.0 & 115.3 \\
\hline 12381.710 & 836.2 & 761.5 & 490.3 & 120.8 \\
\hline 12149.600 & 977.6 & 968.7 & 949.0 & 116.3 \\
\hline 11854.340 & 404.7 & 385.6 & 396.1 & 119.2 \\
\hline 11736.810 & 593.3 & 580.2 & 580.3 & 120.0 \\
\hline 11559.960 & 787.6 & 836.8 & 818.6 & 120.0 \\
\hline 11304.910 & 719.6 & 666.2 & 668.4 & 117.3 \\
\hline 11101.850 & 357.3 & 377.5 & 407.3 & 115.2 \\
\hline 10986.780 & 980.4 & 870.3 & 807.7 & 114.6 \\
\hline 10721.520 & 496.9 & 504.5 & 485.8 & 111.6 \\
\hline 10567.740 & 360.9 & 351.2 & 361.5 & 110.8 \\
\hline 10460.690 & 290.2 & 285.9 & 282.5 & 107.8 \\
\hline 10373.540 & 286.5 & 284.4 & 283.1 & 108.9 \\
\hline 10286.850 & 292.7 & 290.8 & 286.3 & 108.2 \\
\hline 10198.230 & 557.6 & 555.0 & 558.7 & 108.5 \\
\hline 10029.060 & 597.5 & 612.3 & 616.2 & 107.8 \\
\hline 9842.440 & 320.6 & 311.9 & 298.9 & 105.3 \\
\hline 9747.371 & 290.6 & 291.0 & 298.1 & 106.8 \\
\hline 9658.666 & 365.4 & 363.2 & 367.2 & 105.5 \\
\hline 9547.949 & 256.2 & 274.4 & 275.8 & 105.1 \\
\hline 9464.301 & 377.7 & 379.6 & 388.1 & 105.1 \\
\hline 9348.594 & 332.4 & 329.9 & 327.8 & 103.6 \\
\hline 9248.053 & 614.8 & 577.5 & 540.2 & 104.5 \\
\hline 9072.042 & 622.4 & 659.5 & 691.7 & 103.9 \\
\hline 8871.031 & 555.2 & 598.9 & 632.1 & 103.0 \\
\hline 8688.474 & 245.5 & 252.3 & 259.0 & 102.6 \\
\hline 8611.572 & 239.9 & 254.0 & 269.7 & 102.0 \\
\hline 8534.161 & 270.5 & 284.3 & 298.9 & 102.1 \\
\hline 8447.496 & 195.7 & 199.8 & 196.0 & 101.1 \\
\hline 8386.597 & 158.9 & 196.2 & 222.5 & 99.7 \\
\hline
\end{tabular}


Table A1 (cont.). Old Situk River cross sections.

\begin{tabular}{|c|c|c|c|c|}
\hline River station & $\begin{array}{l}\text { Length left } \\
\text { (ft) }\end{array}$ & $\begin{array}{l}\text { Length channel } \\
\text { (ft) }\end{array}$ & $\begin{array}{l}\text { Length right } \\
\text { (ft) }\end{array}$ & $\begin{array}{l}\text { Minimum } \\
\text { channel } \\
\text { elevation } \\
\text { (ft) MLLW }\end{array}$ \\
\hline 8326.782 & 1400.1 & 1409.6 & 1366.5 & 98.5 \\
\hline 7897.146 & 639.9 & 627.9 & 670.0 & 98.6 \\
\hline 7705.768 & 461.2 & 491.7 & 529.4 & 98.3 \\
\hline 7555.914 & 635.7 & 681.5 & 746.7 & 97.5 \\
\hline 7348.190 & 364.4 & 388.8 & 414.4 & 97.6 \\
\hline 7229.700 & 533.3 & 558.6 & 569.2 & 96.0 \\
\hline 7059.429 & 1198.5 & 1231.0 & 1309.7 & 93.2 \\
\hline 6684.209 & 2063.0 & 1956.5 & 1892.7 & 94.0 \\
\hline 6087.883 & 1254.6 & 1255.3 & 1263.5 & 90.9 \\
\hline 5705.273 & 549.8 & 550.3 & 546.2 & 87.2 \\
\hline $5537.55 *$ & 78.3 & 78.6 & 78.1 & 85.8 \\
\hline 5536.770 & Culvert & & & \\
\hline 5513.590 & 469.7 & 471.7 & 468.8 & 85.8 \\
\hline 5369.835 & 648.0 & 650.7 & 660.6 & 84.3 \\
\hline 5171.502 & 442.6 & 424.3 & 410.3 & 84.2 \\
\hline 5042.163 & 3030.3 & 2850.4 & 2701.8 & 81.9 \\
\hline 4173.375 & 1581.9 & 1608.7 & 1663.8 & 78.4 \\
\hline 3683.060 & 2029.8 & 2055.8 & 2065.3 & 75.5 \\
\hline 3056.467 & 1942.2 & 1970.9 & 2023.7 & 70.9 \\
\hline 2455.730 & 504.7 & 505.2 & 502.9 & 68.6 \\
\hline 2301.752 & 1331.9 & 1279.8 & 1236.0 & 68.1 \\
\hline 1911.684 & 1220.1 & 1268.9 & 1323.6 & 64.6 \\
\hline 1524.931 & 2389.5 & 2414.7 & 2428.9 & 63.4 \\
\hline 788.942 & 2473.4 & 2450.8 & 2437.0 & 60.9 \\
\hline 41.952 & 137.6 & 137.6 & 137.6 & 55.7 \\
\hline
\end{tabular}


Table A2. Upper Situk cross sections.

\begin{tabular}{|c|c|c|c|c|}
\hline River station & $\begin{array}{c}\text { Length left } \\
\text { (ft) }\end{array}$ & $\begin{array}{c}\text { Length channel } \\
\text { (ft) }\end{array}$ & $\begin{array}{c}\text { Length right } \\
\text { (ft) }\end{array}$ & $\begin{array}{c}\text { Minimum } \\
\text { channel } \\
\text { elevation } \\
\text { (ft) MLLW }\end{array}$ \\
\hline 38314.78 & 1644.3 & 1609.9 & 1595.4 & 142.1 \\
\hline 37824.09 & 1767.1 & 1790.3 & 1801.7 & 138.0 \\
\hline 37278.41 & 1554.9 & 1511.1 & 1509.7 & 134.1 \\
\hline 36817.82 & 1336.7 & 1429.8 & 1549.7 & 131.4 \\
\hline 36382.03 & 2467.5 & 2434.2 & 2451.5 & 126.5 \\
\hline 35640.08 & 2533.8 & 2458.8 & 2420.1 & 121.3 \\
\hline 34890.63 & 779.5 & 813.4 & 850.6 & 112.2 \\
\hline 34642.70 & 619.2 & 639.5 & 664.3 & 110.2 \\
\hline 34447.77 & 644.3 & 651.8 & 661.3 & 110.5 \\
\hline 34249.10 & 902.4 & 910.7 & 914.5 & 107.8 \\
\hline 33971.53 & 781.3 & 764.2 & 748.0 & 103.6 \\
\hline 33738.60 & 1931.7 & 1800.1 & 1680.5 & 102.7 \\
\hline 33189.94 & 806.0 & 807.5 & 831.3 & 97.8 \\
\hline 32943.83 & 1907.0 & 1797.0 & 1778.3 & 94.2 \\
\hline 32396.09 & 2153.2 & 2177.7 & 2234.8 & 92.9 \\
\hline 31732.34 & 1021.5 & 1038.3 & 1048.6 & 89.4 \\
\hline 31415.87 & 1372.8 & 1389.9 & 1404.2 & 87.7 \\
\hline 30992.22 & 1565.6 & 1546.5 & 1576.0 & 84.9 \\
\hline 30520.85 & 1256.1 & 1240.3 & 1169.2 & 82.3 \\
\hline 30142.81 & 2105.0 & 2023.0 & 2061.5 & 78.7 \\
\hline 29526.19 & 1562.5 & 1606.8 & 1576.0 & 75.6 \\
\hline 29036.43 & 938.3 & 956.8 & 1015.5 & 73.3 \\
\hline 28744.81 & 2048.1 & 2107.1 & 2388.8 & 72.0 \\
\hline 28102.58 & 102.0 & 99.4 & 100.8 & 69.8 \\
\hline 27557.50 & 600.7 & 582.3 & 575.4 & 66.3 \\
\hline 27380.02 & 1108.3 & 1119.7 & 1134.0 & 68.6 \\
\hline 27038.75 & 7114.9 & 6893.9 & 6843.8 & 68.7 \\
\hline 24937.50 & 2065.7 & 2084.3 & 2126.0 & 59.3 \\
\hline 24302.20 & 249.9 & 249.9 & 249.9 & 58.7 \\
\hline & & & & \\
\hline
\end{tabular}


Table A3. Lower Situk cross sections.

\begin{tabular}{|c|c|c|c|c|}
\hline River station & $\begin{array}{c}\text { Length left } \\
\text { (ft) }\end{array}$ & $\begin{array}{c}\text { Length channel } \\
\text { (ft) }\end{array}$ & $\begin{array}{c}\text { Length right } \\
\text { (ft) }\end{array}$ & $\begin{array}{c}\text { Minimum } \\
\text { channel } \\
\text { elevation } \\
\text { (ft) MLLW }\end{array}$ \\
\hline 24226.020 & 1205.3 & 1177.3 & 1158.7 & 55.1 \\
\hline 23867.190 & 789.3 & 796.1 & 805.3 & 57.2 \\
\hline 23624.530 & 1138.0 & 1165.7 & 1195.9 & 53.9 \\
\hline 23269.220 & 1465.9 & 1510.3 & 1511.6 & 55.8 \\
\hline 22808.880 & 416.6 & 424.2 & 437.6 & 53.2 \\
\hline 22679.580 & 1036.6 & 1052.5 & 1055.9 & 52.4 \\
\hline 22358.790 & 1733.0 & 1753.0 & 1772.7 & 50.4 \\
\hline 21824.490 & 2964.3 & 3035.6 & 3013.7 & 50.6 \\
\hline 20899.240 & 1230.1 & 1267.3 & 1250.0 & 46.7 \\
\hline 20512.980 & 1757.6 & 1736.1 & 1721.4 & 47.3 \\
\hline 19983.810 & 1191.9 & 1201.3 & 1243.8 & 46.3 \\
\hline 19617.650 & 1316.1 & 1314.4 & 1325.0 & 43.6 \\
\hline 19217.010 & 3237.7 & 3225.3 & 3273.6 & 41.7 \\
\hline 18233.930 & 2566.1 & 2566.6 & 2511.2 & 36.9 \\
\hline 17451.630 & 1829.6 & 1773.8 & 1814.6 & 35.2 \\
\hline 16910.970 & 3182.4 & 3102.9 & 3127.4 & 35.6 \\
\hline 15965.210 & 1210.3 & 1185.8 & 1200.2 & 32.9 \\
\hline 15603.770 & 902.1 & 892.3 & 892.5 & 33.1 \\
\hline 15331.790 & 2093.3 & 2037.0 & 2053.0 & 29.1 \\
\hline 14710.920 & 1338.8 & 1293.9 & 1241.0 & 23.8 \\
\hline 14316.530 & 577.2 & 577.1 & 579.0 & 27.3 \\
\hline 14140.640 & 1003.5 & 1008.6 & 1011.7 & 27.4 \\
\hline 13833.220 & 574.0 & 573.9 & 573.0 & 26.1 \\
\hline 13658.290 & 700.5 & 700.6 & 700.3 & 23.6 \\
\hline 13444.770 & 656.0 & 655.2 & 652.9 & 21.6 \\
\hline 13245.060 & 3164.4 & 3128.2 & 3136.1 & 20.6 \\
\hline 12291.580 & 1346.9 & 1329.9 & 1323.9 & 17.2 \\
\hline 11886.230 & 2671.0 & 2597.5 & 2588.4 & 17.1 \\
\hline 11094.500 & 1561.0 & 1543.2 & 1557.5 & 15.4 \\
\hline 10624.120 & 1887.7 & 1659.3 & 1675.9 & 15.7 \\
\hline 10118.370 & 2642.9 & 2715.9 & 2691.4 & 13.6 \\
\hline 9290.577 & 1746.6 & 1710.9 & 1685.7 & 11.1 \\
\hline 8769.091 & 1122.7 & 1119.0 & 1109.0 & 6.9 \\
\hline 8428.029 & 1655.8 & 1657.6 & 1659.8 & 5.0 \\
\hline 7922.809 & 1780.2 & 1734.6 & 1795.3 & 3.0 \\
\hline 7394.112 & 2136.3 & 2129.4 & 2150.7 & 2.0 \\
\hline 6745.062 & 1790.7 & 1777.2 & 1745.0 & 1.0 \\
\hline 6203.375 & 1302.8 & 1351.7 & 1466.8 & 0.0 \\
\hline 5791.375 & 3439.2 & 2108.4 & 1488.8 & -10.0 \\
\hline 5148.741 & 8744.0 & 8209.1 & 5898.6 & -10.0 \\
\hline 2646.613 & 4349.2 & 6952.4 & 8673.0 & -10.0 \\
\hline 527.527 & 1824.2 & 1539.4 & 1716.6 & -20.0 \\
\hline 55.029 & & & & -75.0 \\
\hline & & & & \\
\hline
\end{tabular}




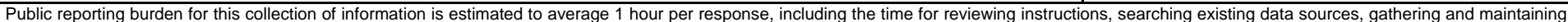

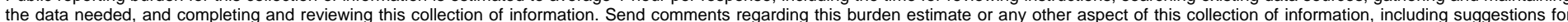

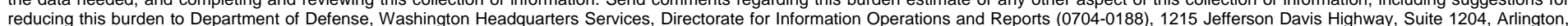

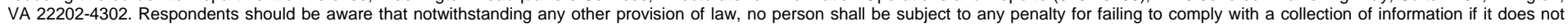
display a currently valid OMB control number. PLEASE DO NOT RETURN YOUR FORM TO THE ABOVE ADDRESS.

\begin{tabular}{l|l} 
1. REPORT DATE (DD-MM-YYYY) & 2. REPORT TYPE \\
March 2011 & Technical Report
\end{tabular}

\section{TITLE AND SUBTITLE}

Situk River Hydrology Following Closure of Russell Fiord by Hubbard Glacier
3. DATES COVERED (From - To)

5a. CONTRACT NUMBER

5b. GRANT NUMBER

5c. PROGRAM ELEMENT NUMBER

5d. PROJECT NUMBER

5e. TASK NUMBER

5f. WORK UNIT NUMBER

8. PERFORMING ORGANIZATION REPORT NUMBER

ERDC/CRREL TR-11-5

U.S. Army Engineer Research and Development Center

Cold Regions Research and Engineering Laboratory

72 Lyme Road

Hanover, NH 03755-1290

9. SPONSORING / MONITORING AGENCY NAME(S) AND ADDRESS(ES)

12. DISTRIBUTION / AVAILABILITY STATEMENT

Approved for public release; distribution is unlimited.

Available from NTIS, Springfield, Virginia 22161.

13. SUPPLEMENTARY NOTES

\section{ABSTRACT}

The impact on the hydrology of the Situk River of a sustained closure of Alaska's Russell Fiord by Hubbard Glacier is described. A hydrological model was developed and used to estimate the daily inflows into Russell Lake (created by the closure of Russell Fiord). These daily inflows, when routed through Russell Lake, determine the flow into the Old Situk River after the Russell Lake level has risen approximately $137.2 \mathrm{ft}$. A HEC-RAS one-dimensional flow model estimated the levels and flows of the Situk River system, including the Old Situk, Upper Situk, and Lower Situk Rivers. The channel geometry was based on an extensive LiDAR survey conducted in 2005. The levels and flows in the Situk River system were simulated over a 15-year period using the estimated daily outflows from Russell Lake to determine the hydrology of the Situk River system. The flow percentiles, annual exceedance probabilities, and average daily flows were estimated. The flow profiles were used to develop inundation maps and investigate potential channel erosion, the impacts on the Old Situk River crossing and Situk Lake, and the potential impacts of log jams and channel migration.

\begin{tabular}{|ll}
\hline 15. SUBJECT TERMS & Russell Fiord \\
Alaska & Russell Lake \\
Hubbard Glacier & Situk River \\
\hline
\end{tabular}

16. SECURITY CLASSIFICATION OF:

\begin{tabular}{|c|c|c|}
\hline a. REPORT & b. ABSTRACT & c. THIS PAGE \\
$\mathrm{U}$ & $\mathrm{U}$ & $\mathrm{U}$ \\
\hline
\end{tabular}

\begin{tabular}{c|c} 
17. LIMITATION & \\
OF ABSTRACT & \\
$U$ &
\end{tabular}

18. NUMBER
OF PAGES

73 19a. NAME OF RESPONSIBLE PERSON

19b. TELEPHONE NUMBER (include area code) 